NBER WORKING PAPER SERIES

\title{
UNEXPLOITED GAINS FROM INTERNATIONAL DIVERSIFICATION: PATTERNS OF PORTFOLIO HOLDINGS AROUND THE WORLD
}

\author{
Tatiana Didier \\ Roberto Rigobon \\ Sergio L. Schmukler \\ Working Paper 16629 \\ http://www.nber.org/papers/w16629 \\ NATIONAL BUREAU OF ECONOMIC RESEARCH \\ 1050 Massachusetts Avenue \\ Cambridge, MA 02138 \\ December 2010
}

\begin{abstract}
For very helpful comments, we would like to thank Andres Almazan, Fernando Broner, Ricardo Caballero, Charlie Calomiris, V.V. Chari, Bob Gibbons, Julian di Giovanni, Alejandro Drexler, Pierre- Olivier Gourrinchas, Graciela Kaminsky, Mark Kritzman, Michael Klein, Tarun Ramadorai, Rafael Repullo, Dani Rodrik, Rafael Chaves Santos, Luis Servén, Steven Snider, Frank Warnock, and participants at presentations held at the AEA Annual Meetings (Chicago), the European Central Bank, Harvard University, the IMF, the IMF Ninth Jacques Polak Annual Research Conference, the LACEA Annual Meetings (Buenos Aires and Mexico City), MIT, the NBER Summer Institute, the NIPFP-DEA Workshop on Capital Flows (New Delhi), and the XII Workshop in International Economics and Finance (Rio de Janeiro). We are grateful to Tiago Caruso, Francisco Ceballos, Juan Carlos Gozzi, Jennifer Kim, Ricardo Leal, Paula Pedro, Mercedes Politi, Virginia Poggio, Juliana Portella, and Mira Olson, who provided excellent research assistance at different stages of the project, and Judith Goff, who helped with the editing. The World Bank provided generous financial support through its research program. The views expressed here do not necessarily represent those of the World Bank or the National Bureau of Economic Research.
\end{abstract}

NBER working papers are circulated for discussion and comment purposes. They have not been peerreviewed or been subject to the review by the NBER Board of Directors that accompanies official NBER publications.

(C) 2010 by Tatiana Didier, Roberto Rigobon, and Sergio L. Schmukler. All rights reserved. Short sections of text, not to exceed two paragraphs, may be quoted without explicit permission provided that full credit, including $\odot$ notice, is given to the source. 
Unexploited Gains from International Diversification: Patterns of Portfolio Holdings Around the World

Tatiana Didier, Roberto Rigobon, and Sergio L. Schmukler

NBER Working Paper No. 16629

December 2010

JEL No. F30,F36,G11,G15,L20

\section{ABSTRACT}

This paper studies how portfolios with a global investment scope are actually allocated internationally using a unique micro dataset on U.S. equity mutual funds. While mutual funds have great flexibility to invest globally, they invest in a surprisingly limited number of stocks, around 100. The number of holdings in stocks and countries from a given region declines as the investment scope of funds broadens. This restrictive investment practice has costs. A mean-variance strategy shows unexploited gains from further international diversification. Mutual funds investing globally could achieve better risk-adjusted returns by broadening their asset allocation, including stocks held by more specialized funds within the same mutual fund family (company). This investment pattern is not explained by lack of information or instruments, transaction costs, or a better ability of global funds to minimize negative outcomes. Instead, industry practices related to organizational factors seem to play an important role.

Tatiana Didier

The World Bank

1818 H Street NW

MSN I8-808

Washington, DC - 20433

tdidier@worldbank.org

Roberto Rigobon

MIT Sloan School of Management

100 Main Street, E62-516

Cambridge, MA 02142

and NBER

rigobon@mit.edu
Sergio L. Schmukler

The World Bank

MSN MC3-301

1818 H Street, N.W.

Washington, DC 20433

Sschmukler@worldbank.org 


\section{Introduction}

The increase in global financial integration over the last twenty years has been remarkable, and U.S. institutional investors that purchase foreign assets have been significant participants in this growth. ${ }^{1}$ Given standard economic theory, one would expect to see greater international diversification accompanying the expansion of global investment opportunities. Indeed, a number of studies show the gains that may be achieved from such diversification. ${ }^{2}$ To date, however, evidence on how investors actually allocate their portfolios around the world and what determines it is still limited.

In this paper, we aim to fill the gap in the literature by constructing a unique micro dataset of asset-level portfolios for a group of important institutional investors. We then document the main stylized facts regarding their global asset allocations and study the factors behind their portfolio decisions, in particular how the organizational structure of financial intermediaries affects international investments. To conduct the research, we analyze U.S. equity mutual funds with an international investment scope. We find that, although mutual funds that invest globally have significantly expanded the size of their assets, they have been noticeably restrictive in the range of stocks they hold. In fact, they tend to invest in about the same number of stocks (100 stocks) than mutual funds with a more limited (regional or country) mandate do. Moreover, they forgo potential gains from international diversification. This investment practice is not explained by lack of information or instruments, transaction costs, or a better ability of global mutual funds to minimize tail risk. Instead, it seems to be largely driven by industry practices related to how mutual fund families structure their operations. These organizational factors seem important to understand how managers and families (companies) allocate their portfolios internationally.

\footnotetext{
${ }^{1}$ See, for example, Obstfeld and Taylor (2004), Stulz (2005), and Kose, Prasad, Rogoff, and Wei (2009).

${ }^{2}$ On the supply side of funds, investors can reduce risk for a given level of expected returns (or increase returns for a given level of risk) by investing internationally. A number of studies provide some evidence on the gains from international diversification. See, for example, Grubel (1968), Harvey (1995), De Santis and Gerard (1997), Errunza, Hogan, and Hung (1999), De Roon, Nijman, and Werker (2001), Goetzmann, $\mathrm{Li}$, and Rouwenhorst (2005), and Driessen and Laeven (2007). On the demand side, firms and governments can reduce the cost of capital, finance new projects, and decrease the exposure of their balance sheets to some domestic macroeconomic shocks by tapping international investors. See, for example, Rajan and Zingales (1998), Stulz (1999), Van Wincoop (1999), Bekaert and Harvey (2000), and Gozzi, Levine, and Schmukler (2008).
} 
Focusing on mutual funds offers important advantages. First, mutual funds, unlike other types of institutional investors, such as hedge funds, pension funds, and individual international investors, face regular reporting requirements. Thus, asset-level portfolios for mutual funds can be constructed and traced over time since their inception. Second, the structure of mutual fund families allows us to make within-family comparisons of the behavior of "specialized funds," which can invest only in certain countries or regions, and "global funds," which can invest anywhere in the world and thus have access to a larger set of instruments (more firms from more countries). Knowing that a fund within a mutual fund family holds certain stocks is an indication that the transaction costs to hold them are not exceedingly large and that those stocks are indeed desirable (at least to other fund managers within the same family). Moreover, information about those stocks has already been collected at the family level and, in principle, might be available to all managers in that family. Therefore, the relevance of information sharing, transaction costs, and industrial organization aspects discussed in the literature can be analyzed by comparing portfolios across funds within the same mutual fund family and across families. In addition, the returns of specialized funds can be compared to those of global funds, shedding light on the payoffs of different investment strategies.

We collect portfolio holding and return data for the universe of actively managed open-ended U.S. mutual funds established to purchase assets around the world. The data on holdings contain asset-level annual portfolios between 1991 and 2005. We work with a total of 499 fund families and 1,904 funds. The total number of fund-year observations is 8,420 and the total number of asset-level holdings for all funds in all years is $1,359,750$. The portfolio holdings have been matched to identify the country to which each stock belongs, tracking holdings over time. We use daily returns at the fund level between September 1989 and June 2006 for 36 fund families that have a variety of mutual funds for which useful comparisons can be made. ${ }^{3}$ We work with a total of 722,885 daily observations, comprising returns for all funds from these families.

Three stylized facts about mutual fund international investments emerge from our analysis. First, global funds have grown much more than specialized funds. For example,

\footnotetext{
${ }^{3}$ For the return data, we focus on the largest mutual fund families in terms of assets under management and/or number of individual mutual funds. We are constrained by the need to concentrate on families with both global and specialized funds to make useful comparisons.
} 
in 1992, assets under management by global funds were about three times as large as those managed by specialized funds; by 2004, global funds had grown to be six times as large (US\$530 billion) as specialized funds (US\$89 billion). Second, both specialized and global mutual funds hold a similar number of stocks (the average number of stocks is 150 and the median 95). In other words, the number of asset holdings in mutual fund portfolios does not tend to be higher for global funds compared to specialized funds within the same mutual fund family, even though the pool of investable assets is significantly larger for global funds. For example, global funds belonging to Oppenheimer Funds held on average 100 stocks in 2004 while its emerging market fund invested in 125 stocks. Similarly, in 2004, AIM Family of Funds' global funds held 105 stocks on average, whereas its specialized funds held 102 stocks on average. Third, within each region of exposure, global funds hold fewer assets from fewer countries when compared to specialized funds within the same mutual fund family. For instance, in the case of Latin American holdings, the median specialized fund holds 41 stocks, whereas global funds hold only around three stocks ( $94 \%$ fewer stocks than specialized funds within their mutual fund families). Furthermore, global funds also invest in $75 \%$ fewer countries in Latin America than specialized funds (about two countries compared to six). The restrictive pattern of investment by global funds is relevant as global funds are investing an increasing amount of funds in stocks from a limited set of companies and countries. The natural question is then, what can rationalize this investment pattern.

We argue, first, that instrument availability and transaction costs do not appear to explain the stylized facts mentioned above. To start, mutual funds could increase the number of stocks they hold since there are many stocks available for investment that are not included in mutual fund portfolios. For example, in the case of Vanguard funds, even though they tend to invest in many more stocks than funds from other families, the number of stocks they hold still seems relatively small. In 2004, Vanguard funds held 482 stocks on average while the number of listed stocks worldwide was more than 39,000. While high transaction costs could be an impediment to expand the number of stocks in the portfolios (not all listed stocks could be bought at a low cost), they do not seem to be driving the results either. The cross-fund comparison is revealing regarding transaction costs. More specifically, the fact that one particular fund holds a certain stock is an 
indication that there are no clear investment restrictions related to that company. Furthermore, mutual funds hold, on average, a very small fraction of market capitalization. Global fund and specialized fund investments account (separately) for just $0.12 \%$ of firms' market capitalization. This suggests that mutual funds are not large relative to the stocks they hold and thus might be able to increase their exposures without incurring major costs. In the case of global funds, they could also expand the range of assets they hold by investing in the same stocks that specialized funds hold (to the extent that specialized funds are not heavily exposed to the average company).

Second, we find that lack of information at the mutual fund family level alone does not seem to explain the apparent lack of international diversification. If global and specialized funds within families shared information and made similar decisions, one should observe that they hold similar portfolios (or that global funds follow specialized funds to the extent that the latter know better each particular country or region). However, we do not find evidence consistent with managers using, to a large extent, information already gathered and/or processed by other managers within the same mutual fund family. For example, global and specialized funds share only $16 \%$ of their holdings (or, on average, $36 \%$ of net asset value of investments). Moreover, portfolios become more similar when global and specialized funds are managed by some of the same managers; and the similarity increases with the number of common managers. Thus, to the extent that it is costly to gather and process information and managers compete with each other within families, one would observe portfolio choices consistent with the ones documented in this paper. In sum, industrial organizational aspects of the mutual fund industry could partly explain the restrictive international investment practices.

Third, we show that mutual fund family effects appear to be a strong driving factor of the portfolio choices of individual funds. For example, funds in the Templeton Group held on average 129 stocks in 2005, significantly fewer than the 517 stocks held on average by funds in the Vanguard Group. In fact, family effects explain almost $50 \%$ of the cross-sectional and time-series variation in the number of stock holdings and the portfolio loadings on the top ten holdings, vastly exceeding the explanatory power of commonly used measures that capture the ability of funds and managers to gather and process information and make portfolio choices. These family effects point to the 
importance of organizational norms at the company level that determine how different funds pick stocks, and go beyond restrictions and organizational practices at the fund level that affect how each individual fund allocates its portfolio. Family effects are not fully captured by the observables we have included in the estimations and may encompass, among others, norms about investment policies, top management preferences and practices, and internal optimization algorithms.

The fact that global funds do not tend to hold more stocks than specialized funds does not necessarily imply a diversification loss. If assets within and across countries were perfectly correlated, global funds could obtain the same degree of diversification benefits as specialized funds do by simply holding fewer stocks, possibly in fewer countries. Thus, return correlations could account for the patterns observed in the data, implying no return losses or excessive variance for investors. To explore this issue, we use first a mean-variance optimization framework to estimate the performance of simulated global funds (constructed as a portfolio of specialized funds from the same global fund family) and compare it to the performance of actual global funds. ${ }^{4}$ By definition, this is a very restrictive exercise, since simulated global funds cannot choose among all the stocks available to specialized funds, but rather they must invest in a portfolio already held by another fund within their fund family. This guarantees that the stocks are available for investment (i.e., that we are considering a feasible set), that they are attractive to at least one other manager in the same family, and that information about the stocks was already collected and analyzed by someone relatively close to the global fund manager. Our results suggest that there are potential gains from further international diversification. Global funds could obtain better risk-adjusted returns if they invested in portfolios that include holdings similar to those of specialized funds, even within the same mutual fund family. In other words, by not increasing the number of stocks as funds expand their investment scope, global funds forgo the benefits that broader international diversification entails. For example, we find that the average return of global funds could increase between $2.6 \%$ and $5.5 \%$ per year if they maximized daily or weekly returns

\footnotetext{
${ }^{4}$ Each simulated global fund also includes a non-negative weigh on the global fund itself. The nature of this exercise is different from the one performed by Evans and Archer (1968), which studies how the variation of returns for randomly selected portfolios changes as a function of the number of securities in the portfolio.
} 
following a mean-variance approach. The results are robust to many types of estimations that take into account expected returns, variances, and benchmark effects.

We also use the simulated global funds to look beyond a mean-variance framework and explore the possibility that there is an insurance premium in the returns of global funds. Because global funds, unlike specialized funds, can secure gains by moving away from troubled countries during crisis times, investors might be willing to pay for this benefit by accepting lower expected returns. Our results indicate that global funds do not seem to better shield investors from tail risk. We find that the skewness and kurtosis of global fund returns are similar to those of the simulated global funds. Higher moments of the distribution of returns are important if global funds were to minimize losses during bad times instead of following standard mean-variance models. Moreover, conditional on large negative returns on either specialized funds or the MSCI Emerging Market Index, we find that returns of the simulated global funds are broadly similar to those of global funds. In sum, the lack of diversification does not seem to be explained by a better performance of global funds during turbulent times. It is nevertheless possible that global funds provide some other unobservable benefits that are not captured by the meanvariance and other analyses performed in this paper.

Our findings contribute to several strands of the literature. First, our paper relates to a large literature on the extent of investor international diversification. Most of this research has concentrated on aggregate measures to explain the determinants of international investments and on country portfolios to study the degree to which countries hold assets abroad. ${ }^{5}$ More recently, researchers have begun to exploit asset-level data based on institutional investor portfolios, although the evidence remains scarce. ${ }^{6}$ Our findings on mutual funds with global reach reinforce the existing evidence of growing but still limited international diversification. Furthermore, our results provide evidence that some of the usual explanations for these international investment patterns, such as the relevance of transaction costs and the lack of available information, are not sufficient to

\footnotetext{
${ }^{5}$ A large part of the literature has focused on the home bias puzzle, starting with the seminal work of French and Poterba (1991). See Tesar and Werner (1995), Brennan and Cao (1997), Kraay, Loayza, Serven, and Ventura (2005), Portes and Rey (2005), Aviat and Coeurdacier (2007), Lane and MilesiFerretti (2008), among many others.

${ }^{6}$ See, for example, Strong and Xu (2003), Cai and Warnock (2006), Eun, Huang, and Lai (2008), and Hau and Rey (2008).
} 
fully address the findings in this paper. ${ }^{7}$ Limited information does not seem to be a driver of limited international diversification in the sense that information is available at the mutual fund family level. The problem arises on how information is shared across funds within a family. Moreover, the lack of diversification is not driven by the inability of global funds to purchase more securities or at least the same securities that specialized funds hold, since each individual fund invests in relatively few stocks, the fund allocations are small compared to the size of the market, and specialized funds tend to hold more securities in each country and region. In other words, the results do not seem to be driven by instrument availability or transaction costs. Instead, our findings suggest that organizational factors within the finance industry, overlooked by the international literature, explain at least in part the limited degree of international diversification.

Second, we contribute to the literature on how financial markets work by studying portfolios within and across mutual fund families, which sheds light on the drivers of international portfolio allocations. The industrial organization literature, broadly understood, emphasizes the role of management practices in affecting corporate behavior. ${ }^{8}$ Furthermore, this literature highlights the relevance of idiosyncratic firm effects (beyond the usual factors related to the production function, plant effects, demand factors, or even managerial effects) in explaining corporate behavior, diversification strategies (across products), productivity, and performance. ${ }^{9}$ Our findings on mutual funds are consistent with those in the organizational economics literature, in the sense that routines and internal practices (instead of pure financial diversification considerations) appear to affect global asset allocation. For instance, the existence of within-family competition among managers seems to be behind our finding of low commonality in portfolio holdings across mutual funds within a given family; namely, mutual fund families seem to be organized in a way that makes their own managers

\footnotetext{
${ }^{7}$ See, for example, Kang and Stulz (1997), Dahlquist and Robertsson (2001), Grinblatt and Keloharju (2001), and Daude and Fratzscher (2008).

${ }^{8}$ See Ichniowski, Shaw, and Prennushi (1997), Black and Lynch (2001), Bertrand and Schoar (2003), Lafontaine and Shaw (2005), and Bloom and van Reenen (2007), among many others. In particular, Gibbons and Henderson (2010) argue that differences in performance across firms arise because of different management practices, which depend on relational contracts that are not easy to imitate.

${ }^{9}$ See, for example, Griliches and Mairesse (1983), Griliches (1986), Montgomery and Wernerfelt (1988), Baily, Hulten, Campbell, Bresnahan, and Caves (1992), Cohen and Bacdayan (1994), Henderson and Cockburn (1996), Bartelsman and Doms (2000), and Nelson and Winter (2002), among many others.
} 
compete and not talk to each other. ${ }^{10}$ Moreover, our evidence that the number of stocks held across mutual funds and the portfolio loadings on the top ten holdings are significantly explained by family effects, with a limited role for investment mandates, suggests that the organization of each company in particular and the financial industry in general might be an important factor in determining how financial intermediaries allocate their portfolios across countries. ${ }^{11,12}$

A related but separate strand of the literature discusses the role of incentives in affecting manager behavior. In particular, the finance literature highlights a misalignment between the incentives of managers of financial intermediaries (e.g. banks, hedge funds, and mutual funds) and those of the underlying investors, which may lead to long-lasting mispricings and cause managers to hold suboptimal portfolios from the investors' perspective. ${ }^{13}$ Our paper finds evidence consistent with the view that fund managers do not hold optimal international portfolios from the investors' point of view if a meanvariance framework is considered, to the extent that the underlying investors hold their global allocation through global funds.

Lastly, we contribute to the literature on the investment patterns of institutional investors and mutual funds specifically. Part of this literature has focused on U.S. mutual fund domestic investments. ${ }^{14}$ Another strand has studied investment patterns of institutional investors in emerging markets. ${ }^{15}$ By analyzing mutual funds with different investment scopes as well as their portfolio choices over relatively long time series, we

\footnotetext{
${ }^{10}$ See, for example, Hong, Kubik, and Stein (2005) and Kempf and Ruenzi (2008). In separate work, Csaszar (2009) explores how organizational structures affect mutual funds stock-picking behavior.

${ }^{11}$ In related work, Pollet and Wilson (2008) analyze U.S. domestic mutual funds and find that funds respond to asset growth by increasing the investments in their current holdings rather than the number of holdings in their portfolios (implying higher diversification). Moreover, funds with many siblings diversify less rapidly as they grow, suggesting that the fund family may influence a fund's portfolio strategy.

${ }^{12}$ Though part of the literature has addressed issues related to mutual fund families, it has, however, focused on the decisions of the top management of a family and the existence of cross-fund subsidization to promote "high value" funds. See, for example, Nanda, Wang, and Zheng (2004) and Gaspar, Massa, and Matos (2006).

${ }^{13}$ Some papers argue that perverse incentives might lead to excessive manager risk taking and sub-optimal decisions, whereas others suggest the opposite effect. See Shleifer and Vishny (1990), Bebchuk and Stole (1993), Brown, Harlow, and Starks (1996), Chevalier and Ellison (1997, 1999), Dow and Gorton (1997), Bolton, Freixas, and Shapiro (2004), Stein (2005), and Rajan (2006), among others.

${ }^{14}$ See, for example, Grinblatt and Titman (1992), Jegadeesh and Titman (1993), Grinblatt, Titman, and Wermers (1995), Carhart (1997), Wermers (1999).

${ }^{15}$ See Kang and Stulz (1997), Choe, Kho, and Stulz (1999), Dahlquist and Robertsson (2001), Kim and Wei (2002), Edison and Warnock (2004), Kaminsky, Lyons, and Schmukler (2004), Chan, Covrig, and Ng (2005), Gelos and Wei (2005), Broner, Gelos, and Reinhart (2006), among many others.
} 
present new evidence on how mutual funds behave and explore how the organization of financial intermediaries can affect the investment decisions they make across countries and regions.

The rest of the paper is organized as follows. Section 2 describes the data. Section 3 studies how U.S. mutual funds allocate their portfolios internationally. Section 4 analyzes the factors behind the degree of international diversification. Section 5 studies whether there are potential costs and gains to the international diversification strategies of global funds. Section 6 concludes.

\section{Data}

To conduct the analysis, we use data on U.S. equity mutual funds established to purchase assets around the world. ${ }^{16}$ The U.S. mutual fund industry is very large (in 2005 there were 8,044 mutual funds with a market capitalization of US\$ 8 trillion, or $69 \%$ of U.S. GDP), has a strong international presence (according to some estimates, U.S. mutual funds represent more than $70 \%$ of the assets held worldwide by all mutual funds), channels a significant share of retirement savings (mutual funds captured $24 \%$ of retirement savings in the U.S. in 2004), and is a relatively mature and sophisticated industry. We use two types of data: mutual fund holdings and mutual fund returns.

Mutual fund holdings are available from Morningstar, a company that collects mutual fund data. We analyze reports from March 1992 (when they became available) until June 2006. While some mutual funds provide monthly reports, most do so quarterly or semiannually (depending on the reporting SEC rules at the time). Given this heterogeneity in the release of new information, we construct our database with the last reported portfolio information for each fund in any given year. For example, our sample of mutual fund holdings for 2005 contains portfolio data for the Fidelity Worldwide Fund as of October 2005 and portfolio data for the Scudder Global Fund as of December 2005. In sum, we collect end-of-year detailed information on portfolio holdings between 1991

\footnotetext{
${ }^{16}$ Funds that focus on both debt and equity are excluded from the analysis, even though they do invest a significant share of their portfolios in foreign stocks.
} 
and 2005. We collect stock names, amount invested in each stock by each fund, and country of origin of these stocks. ${ }^{17}$

One difficulty in constructing the holdings database is that mutual funds report their asset allocation separately over time, that is, their holdings are not linked and do not tend to have identifiers across reports. Therefore, each security needs to be identified at each point in time. This is not a simple task as stock identifiers are rarely available and, when they are, they are not always unique. We match these holdings across mutual funds over time based on the country of origin (when available) and the stock name for each security holding. We can then determine whether the same stocks appear in different mutual fund portfolios across and within fund families.

Table 1 describes the data. We collect data on 8,420 fund-year portfolio holdings over the period 1991 to 2005, covering 499 mutual fund families (companies) and a total of 1,904 funds. Each mutual fund family has on average four different mutual funds. Some families sell the same portfolio to investors under different names depending on their fee structure and minimum investment requirements. In this paper, we consider these different funds (with identical portfolios) only once; i.e., we do not treat them as separate funds as Morningstar does. ${ }^{18}$ The total number of asset-level observations in our dataset is $1,359,750$, counting each stock-level allocation across all funds over time.

The U.S. mutual fund industry is organized by splitting funds according to their investment scope (Figure 1). In particular, funds are classified into five categories: world funds, foreign funds, emerging market funds, regional funds, and country funds. Regional funds are divided into: Asia (and Pacific) funds, Europe funds, and Latin America (and the Caribbean) funds. ${ }^{19}$ World funds invest all over the world including the U.S., while foreign funds invest around the world excluding the U.S. Emerging market funds invest only in emerging market assets. ${ }^{20}$ Regional and country funds invest only in a particular

\footnotetext{
${ }^{17}$ We classify holdings according to the country of origin of the company issuing the stock, independent of whether these assets are traded in domestic or international markets.

${ }^{18}$ For example, Fidelity Advisors Funds contain the following Latin America funds with the same portfolio: Fidelity Advisors Latin America A, Fidelity Advisors Latin America B, and Fidelity Latin America T.

${ }^{19}$ Asia funds can actually invest in countries located in both the Asian and the Pacific regions. Latin America funds can also invest in countries in the Caribbean. Some Europe funds also tend to invest in countries in Africa, such as South Africa.

${ }^{20}$ Emerging markets are typically middle-income countries. However, these funds might also invest a small proportion of their portfolios in low-income countries.
} 
region or country, respectively. For ease of exposition, we group funds into two categories: "global funds" and "specialized funds." Global funds encompass world funds and foreign funds. All other fund types are called specialized funds, investing in a subset of the assets available to global funds. Naturally, funds with a wider investment scope (global funds) are always able to invest in the stocks held by specialized funds, but not vice versa.

We also collect data on the time series of return/price data on mutual funds. Since these are open-ended funds, the value of each fund each day reflects the value of their underlying holdings or the net asset value (NAV). To be able to compare returns across funds within families, we restrict our focus to large families with several types of funds. We thus use daily returns at the fund level between September 1989 and June 2006 for 36 mutual fund families, as reported in Table 1. We work with a total of 722,885 daily observations, encompassing all returns for all funds in our sample. We include all funds within a given family of funds. On average, each family has ten different mutual funds. ${ }^{21}$

\section{How Do Mutual Funds Allocate Their Portfolios Globally?}

The U.S. mutual fund industry's activity in international capital markets has expanded sharply since the early 1990s. For example, in 1991 there were fewer than 170 mutual funds established to invest in international equity, while in 2005 there were almost 700 funds. While the number of global funds increased steadily until the early $2000 \mathrm{~s}$, that of specialized funds increased until 1998 and declined since then (Figure 2). This was likely driven by the Asian and Russian crises that seem to have generated a desire to hold funds that can invest more freely around the world. At the end of 2005, there were 490 global funds and 186 specialized funds. In terms of assets under management, the differences are even starker. Global (specialized) funds managed US\$29 (\$7) billion in 1991 and US\$781 (\$160) billion in 2005. This pattern holds across more specific fund types. Foreign funds had the most noticeable increase, with assets under management increasing from US\$10.3 billion to US\$540 billion between 1991 and 2005. In sum, the data show a

\footnotetext{
${ }^{21}$ See Appendix Table 1 for a detailed description of the sample coverage of the price data for each mutual fund family.
} 
clear trend in the U.S. equity mutual fund industry toward funds with a wider investment scope over funds that invest in specific regions or countries.

Given the increasing importance of global funds, it is natural to ask to what extent their portfolios differ from those held by specialized funds and how widespread their investments are. We thus explore to what degree mutual fund holdings vary across different fund types within mutual fund families. In principle, as the investment scope increases, funds should be able to hold more assets across more countries and likely gain opportunities to diversify risk better.

Table 2 presents the average, median, and standard deviation in the number of holdings across mutual fund types over the entire 1991-2005 period, pooling all the data. The table shows that both global and specialized mutual funds hold a similar number of stocks. The median number of holdings for world funds is 106 stocks (76 when excluding U.S. assets). The median number of holdings for foreign funds is 105 stocks, while the median for emerging market funds is 121 stocks. The medians for Europe and Asia funds are 71 and 65 stocks, respectively, while Latin America and country funds hold 56 and 63 stocks, respectively. These median values are lower for more specialized funds. Overall, the number of asset holdings in mutual fund portfolios does not tend to be higher for global funds compared to specialized funds, even though the pool of investable assets is significantly larger for global funds. In addition, Figure 3 shows the median number of holdings for different mutual fund types. The top panel of Figure 3 reports these medians for world funds (with and without U.S. holdings), foreign funds, emerging market funds, and regional funds. The bottom panel displays the number of stocks held by Asia funds, Europe funds, Latin America funds, and country funds. The median number of holdings is surprisingly stable over the 15 -year period and similar across fund types. ${ }^{22}$ Across fund categories there is no clear time pattern. In sum, the data suggest that mutual fund managers tend to invest in a limited number of stocks that does not increase significantly as the investment scope widens. ${ }^{23}$

\footnotetext{
${ }^{22}$ Although not shown, the average number of holdings is also stable over time and similar across fund types.

${ }^{23}$ This pattern does not seem to be unique to mutual funds investing internationally. When repeating this exercise for U.S. mutual funds dedicated to domestic investments and for a popular and broad ETF family (iShares), similar patterns arise.
} 
Do global funds hold fewer assets than specialized funds within each region of exposure, given that the number of stocks held by global funds does not increase significantly relative to specialized funds? The data presented in Table 3 confirm that this is indeed the case. For example, the Latin America funds' median number of assets is 41 . However, emerging market funds (with a greater investment scope) hold on average 34\% fewer assets in this region than the Latin America fund within its mutual fund family. The difference in the number of holdings is even more striking for global funds, which hold 93\% and 94\% less assets in Latin America, respectively for foreign and world funds. Furthermore, foreign and world funds also invest, respectively, in $72 \%$ and $75 \%$ fewer countries in Latin America than their specialized counterparts. For Asia, the numbers suggest a similar pattern. While the median number of holdings for specialized funds is 60, the median number of holdings for foreign and world funds is 35 and 19 assets, respectively, implying a drop of $42 \%$ and $69 \%$ relative to the specialized Asian fund within the same mutual fund company. If the number of countries is considered, global funds also hold assets from significantly fewer countries than Asia funds in the same mutual fund family. Lastly, a similar trend is observed when holdings in developed Europe are considered: global funds hold fewer assets from fewer countries within Europe than specialized funds.

In sum, as their investment scope becomes broader, mutual funds invest larger amounts in fewer stocks and fewer countries within each region of exposure. If asset returns were perfectly correlated this behavior would not be surprising, as there would be no further diversification gains from holding more assets. Several other reasons could also help explain this pattern. These reasons are studied in the rest of the paper.

\section{What Factors Might Explain the Global Portfolio Allocations?}

To understand the factors behind mutual fund investment practices, we first examine the extent to which assets are available for investment and whether mutual funds exhaust those investment opportunities. We also analyze whether transaction costs might hinder further participation in the markets. We then study the degree of stock commonality across funds within families and explore the importance of fund and family effects to illustrate how organizational aspects might affect the way in which mutual funds invest. 


\section{A. Asset Availability and Transaction Costs}

A first step to understanding the extent of international diversification by mutual funds is to analyze the universe of assets in which they can invest. Table 4 reports the size of the universe of stocks in 1997 and 2004. ${ }^{24}$ It shows the total number of listed stocks across different regions for both developed and developing countries. ${ }^{25}$ There were more than 30,000 listed stocks in 1997 and over 39,000 in 2004.

Table 4 also reports the actual number of mutual fund holdings and the percent of holdings relative to the number of locally listed companies for all funds in our dataset (including global funds), and for global funds separately. In 1997, mutual funds invested in about 9,000 different firms from around the world. In developed countries, they held on average $52 \%$ of the listed assets. In developing countries, however, they held only $13 \%$ of the listed stocks. A more pronounced pattern emerges when considering only global funds, which have become very large over the sample period. In 1997, global funds held $38 \%$ (8\%) of the number of stocks in developed (developing) economies.

Table 4 also shows that, although the universe of listed companies has increased between 1997 and 2004, there has been a considerable decline in the number of mutual fund holdings during this period. This decline has not been concentrated in any particular region, but has been more accentuated in developing countries, where a fall of $52 \%$ in asset holdings across all funds is observed. In developed countries, the number of holdings declined $24 \%$. When only global funds are considered, a similar investment pattern emerges. By 2004, their holdings had decreased to $26 \%$ of the listed assets in developed countries. In developing countries, the number of holdings fell approximately $46 \%$ between 1997 and 2004, from $8 \%$ to only 3\% of the number of listed stocks.

Although the number of mutual fund holdings fell between 1997 and 2004, the amount invested in these stocks grew significantly, in both developed and developing countries. Investments in developed countries rose from US\$204 billion in 1997 to US $\$ 446$ billion in 2004, a 119\% increase. In developing countries, investments also more than doubled, increasing from US\$30 billion to US\$62 billion between 1997 and 2004.

\footnotetext{
${ }^{24}$ Assets from the U.S. are excluded from this table because our focus is on the international holdings of mutual funds. Offshore financial centers are also excluded, because while firms typically issue securities in these centers, their main operations are located elsewhere.

${ }^{25}$ Developed countries are high-income countries and developing countries (including emerging economies) are non-high-income countries, according to the World Bank classification of countries.
} 
Thus, a growing amount of funds is being invested in fewer firms, more significantly so in developing countries.

To complement the evidence that mutual fund investments are concentrated in few companies, Figure 4 illustrates how mutual funds invest across countries. The figure plots the ratio of the number of companies held in mutual fund portfolios to the total number of listed companies. These ratios are computed on a yearly basis and reported according to their averages over the 1997-2004 period. Countries are sorted by the extent of mutual fund investment and divided in quintiles. Reinforcing the previous evidence, this figure shows that mutual fund holdings are not spread evenly across countries. For around half of the countries in the sample, mutual funds invest in at most $20 \%$ of the listed companies. In no country do mutual funds exhaust the number of listed stocks. Moreover, only developed countries appear in the highest quintile. Among developing countries, Mexico has the highest ratio (44\%), and among developed countries, the Netherlands has the highest ratio (77\%). In the bottom two quintiles, there are 24 developing countries but only four developed countries.

Another possible explanation for the restricted number of holdings of mutual funds is transaction costs. First, transaction costs could be an impediment to expand the number stocks in mutual fund portfolios since not all listed stocks could be bought at a low cost. However, cross-fund comparisons suggest that transaction costs do not present a strong binding constraint. In particular, the fact that one fund holds a certain stock is an indication that there are no clear investment restrictions related to that company. The evidence presented in Table 3 suggests that, for example, global funds could indeed expand the range of their investments by simply investing in the same stocks that specialized funds hold. Second, mutual funds could be relatively large. For instance, if specialized funds held a large fraction of the available shares, global funds would find it difficult to invest in those stocks without affecting prices.

To investigate whether there are restrictions coming from the supply side of investments, Table 5 reports the size of individual mutual fund holdings relative to firms' market capitalization. The table shows that, on average, mutual funds hold a very small fraction of market capitalization: both global funds and specialized funds account each 
for $0.12 \%$ of firms' market capitalization. ${ }^{26}$ Consequently, if funds wanted to increase the exposure to their current holdings, they could probably do so without generating a significant price impact. Furthermore, the patterns observed regarding mutual fund holdings do not seem to be driven by the inability of global funds to hold more stocks across countries either. For example, if specialized funds were to increase in size by $\$ 900$ million (the average global fund size), their investments on average would only account for $0.53 \%$ of firms' market capitalization. In sum, neither the lack of available assets nor transaction costs seem to present strong binding constraints to the portfolio choices of mutual funds to the extent that mutual funds could increase their current exposures and expand the range of assets they hold without incurring in high costs.

\section{B. Stock Commonality}

Next, we analyze the degree to which funds within families invest in similar stocks to shed light on whether information is shared. To the extent that information is costly to obtain and process and the managers of specialized funds have already decided on an asset allocation and have specific information about their particular countries or regions, global fund managers within the same mutual fund family could benefit from this information and choose among the stocks selected by their peers. In other words, if global and specialized funds within mutual fund families shared information and made similar decisions, one should observe similar portfolios across them. From the evidence presented above on the number of holdings across fund types, we already know that global funds are not holding the same portfolios than specialized funds (they hold fewer stocks within each region), but we do not know whether the stocks picked are actually the same, i.e. a subset of those held by specialized funds. It is also possible that portfolio holdings are not similar across funds within families, which would be the case if managers competed with each other, with each manager gathering its own information.

To assess the portfolio similarity, and hence information sharing across funds within mutual fund families, we ask: what is the likelihood that, within a fund family, a stock held by a specialized fund is also held by a global fund? The within-family comparison is important given the large heterogeneity in holdings across mutual fund

\footnotetext{
${ }^{26}$ The number for global funds and specialized funds is similar because, although global funds are larger than specialized funds, they tend to invest in larger firms in terms of market capitalization.
} 
families (documented in the next sub-section) and the hypothesis of interest, that is, whether fund managers in the same company make similar decisions as a sign of information sharing.

We first compute frequency counts to study the degree of commonality. We consider global and specialized funds within a mutual fund family and count the number of observations for which a stock is held by either one of these two fund types, with each of the almost 400,000 observations being a family-year-stock observation. Then we compute the fraction of the observations in which a stock is held (a) by one fund type but not the other, (b) by both fund types, and (c) by the global fund when there is no specialized fund within the same family that could hold that stock. ${ }^{27}$ We make these comparisons on a yearly basis; for example, we compare a stock held by a specialized fund at time $t$ with the stocks held by the corresponding global fund also at time $t$. By construction, no observation falls into the case in which there is no global fund that could not hold a stock held by a specialized fund; that is, for every specialized fund there is always a global fund within the mutual fund family. ${ }^{28}$ Also by construction there are no observations for which a stock is held by neither the global fund nor the specialized fund. We repeat this exercise considering only holdings in developing countries and breaking global funds into world funds and foreign funds.

The results are shown in Table 6 for all holdings in the top panel and for holdings in developing countries only in the bottom panel. Each cell represents the relative frequency of the observations, that is, the joint probability that global and specialized funds hold/do not hold a particular stock. Conditional probabilities can be obtained by looking at a particular row or column. The evidence from Table 6 suggests that global funds and specialized funds do not hold many stocks in common. When considering all holdings, only $16 \%$ of actual holdings are shared by both fund types; in developing countries, that fraction is $13 \%$. Importantly, only $23 \%$ of the global fund holdings are shared by specialized funds. Moreover, $32 \%$ of the stocks are held by specialized funds alone but not by global funds. The results from Table 6 (bottom panel) also suggest that most of the mutual fund holdings in developing countries are explained by holdings of

\footnotetext{
${ }^{27}$ U.S. assets are excluded from this analysis.

${ }^{28}$ We exclude all family-year-stock observations for which mutual fund families do not have one of the fund types considered in that given year.
} 
specialized funds. For example, $75 \%$ of the stocks held by mutual funds are held by specialized funds but not by global funds. In other words, a mere $25 \%$ of the stocks in developing countries in our sample are held by global funds. Furthermore, conditional on being held by a specialized fund, there is only a $15 \%$ probability that a stock from a developing country is held by a global fund. In sum, relative to specialized funds, global funds seem to be investing in a different set of firms. ${ }^{29}$

The frequency counts shown in Table 6 and Appendix Table 2 measure to what extent mutual funds with different investment scopes hold assets from the same companies. However, that evidence does not take into account the size of mutual fund investments in each stock. It might be possible that, though the range of stocks in which mutual funds invest differs, global and specialized mutual fund portfolios contain a large loading on common stocks. Therefore, mutual fund portfolios could actually be more similar than they appear from the evidence above. The reverse could also be true.

To account for the size of mutual fund investment in each stock, we study entropy or similarity measures that analyze how alike mutual fund investments (measured by the NAV) actually are. The entropy measure is constructed as follows:

$$
\text { Entropy }_{f, t}^{i, j}=\frac{\sum_{s, i} N A V_{s, f, t}^{i}+\sum_{s, j} N A V_{s, f, t}^{j}}{\sum_{i} N A V_{f, t}^{i}+\sum_{j} N A V_{f, t}^{j}},
$$

where Entropy $f_{f, t}^{i, j}$ is measured for all funds within types $i$ and $j$ for each family $f$ at time $t ; i, j \in\{$ global fund, specialized fund $\} ; s$ are stocks common to the portfolio of both funds $i$ and $j$ from family $f$ at time $t$. The measure is calculated for every family in every year. Moreover, this measure is constructed within families, given our focus on commonality in portfolios across mutual funds within mutual fund companies. As above, global funds are then split into world funds and foreign funds. For a given pair of different fund types within the same mutual fund family, the entropy measure is the ratio of the sum of the dollar investment in stocks common to the portfolio of these two fund types over the total net assets of the same funds. This entropy measure can be regarded as

\footnotetext{
${ }^{29}$ Appendix Table 2 splits global funds into world funds and foreign funds and compares them with specialized funds. The results suggest that there is no significant difference in portfolio holdings across global funds: specialized funds invest in a wider set of assets than both world funds and foreign funds. World funds and specialized funds share only $10 \%$ of their holdings. This percentage increases to $15 \%$ when foreign funds are considered.
} 
an upper bound of commonality since it compares global funds to aggregates of all specialized funds within families. If global funds were to be compared separately to each specialized fund, the entropy measure for each of these comparisons would cover only a fraction of the portfolio holdings of global funds and, thus, would tend to be lower than the one used here.

The entropy measure indicates that mutual funds do indeed hold a more similar portfolio than what the frequency counts suggest. However, mutual funds still invest in quite different portfolios. For example, when comparing global and specialized funds, the entropy measure shows that, on average, $36 \%$ of the value of their holdings is in common assets. In contrast, according to Table 6 , only $16 \%$ of the number of their holdings is in the same stocks. The entropy measure is slightly higher in the case of developing countries, reaching on average $42 \%$, compared to the $13 \%$ obtained for the frequency count in Table 6. As shown in Figure 5, the entropy measure is stable over the sample period, and, if anything, it decreases since 2001 (and since 1999 for the case of developing countries), suggesting that there is no rise in commonality over time. Similar patterns are obtained (in unreported results) when splitting global funds by type. Over the entire sample period, the median entropy measure is $26 \%$ when comparing the holdings of world funds and specialized funds and $28 \%$ when comparing those of foreign funds and specialized funds.

Interestingly, the commonality measures increase with the number of common managers across funds within mutual fund families. Figure 6 shows that, as the number of common managers increases, the entropy measures increase. For example, the median entropy for funds with no common managers is $29 \%$, while the median entropy for family-years with at least one common manger across different funds is $43 \%$, and the one with more than three common managers is $65 \%$. Furthermore, Table 7 shows that the number of common managers is statistically significant in explaining the entropy measures, independent of whether all holdings or only holdings in developing countries are considered. As the number of common managers increases, so does the degree of commonality.

Overall, the evidence suggests that lack of information at the mutual fund family level alone does not seem to explain the apparent lack of international diversification. 
The evidence that mutual funds do not tend to hold portfolios that are very similar suggests that managers do not use the information already gathered and processed by other managers within the same mutual fund family, even though the family itself has already incurred the cost of acquiring the information. In other words, similar portfolios would provide evidence consistent with information sharing, which we do not find. Moreover, we find that when managers participate in the portfolio allocation decision of more than one fund in the same family, the portfolios of those funds tend to be more similar. This evidence suggests that managers within families might be actually competing with each other, gathering costly information and picking stocks independently. ${ }^{30}$ Namely, industrial organizational aspects of the mutual fund industry that make managers compete could at least partly explain the restrictive investment patterns we find in the data. Competition among managers might also explain the evidence documented above on the limited number of assets in mutual fund portfolios, independent of their investment scope. To the extent that managers within families gather and process information independently and have similar capacity, they would tend to handle a similar number of stocks. These factors, however, do not explain the variability across families, which we explore next.

\section{Family Effects}

Next, we analyze the role of family effects, beyond fundamentals, in explaining portfolio choices. We do so following the organizational literature, which emphasizes the importance of firm effects (as opposed to plant effects within firms) to understand corporate behavior. Much of this research (e.g., Henderson and Cockburn, 1994 and Klette, 1999) characterizes the existence of these firm effects (family effects in this paper) through firm-level dummies and measures their relevance by the increase in the Rsquared of the regressions. Analogously, Bertrand and Schoar (2003) follow this methodology to analyze the impact of managerial effects on corporate policies and performance. We pursue a similar empirical strategy here.

Before presenting formal empirical evidence, we discuss some simple statistics. While, as mentioned above, the median number of holdings across all fund-year

\footnotetext{
${ }^{30}$ This finding is consistent with the evidence shown by Kempf and Ruenzi (2008) on the existence of a family tournament, i.e. competition among managers within mutual fund families.
} 
observation is 95 stocks, there is significant dispersion, with some funds holding many stocks in some years. For instance, as shown in Figure 7 (top panel), while $73 \%$ of the observations imply holdings below 150 stocks, $9 \%$ of the observations represent holdings of more than 350 stocks. Furthermore, this dispersion in the number of stocks found in the fund-year observations is linked to the variance in the number of stocks held across mutual fund families. In fact, mutual fund families differ substantially in the number of stocks they hold. For example, GAM Funds and Oppenheimer Funds hold on average substantially fewer than 200 stocks, while others (such as Dreyfus Founders and Vanguard Group) hold about two times more. More thoroughly, the bottom panel of Figure 7 shows the median number of stocks per family, sorted from the lowest to the highest number of holdings. The mean of the first quintile of the distribution is 39 stocks, whereas the mean of the fifth quintile is 335 . While there are extreme cases, with the median fund in one family holding 1,094 stocks, most families hold a limited number of stocks, with the mean of the fourth quintile being 122 stocks.

We next test more formally the importance of family effects in explaining both the number of stock holdings (a measure of how widely spread the portfolio is) and, alternatively, the portfolio loadings on the top ten holdings (a measure of portfolio concentration). The top panel of Table 8 reports regressions of the number of holdings (the dependent variable) on year, fund type, and family dummies. Similarly, the bottom panel of Table 8 reports these regressions with the percentage of net assets in the top ten holdings as our dependent variable. The dummy coefficients are not reported, although they are usually significant at the standard confidence levels. Seven different specifications are reported. In the first specification, only year dummies are included. In this case, less than $1 \%$ of the variance in mutual fund holdings or top ten holdings can be explained. Column 2 reports a regression with fund type dummies alone. Again, a small percentage (only $2 \%$ ) of the variance of the number of mutual fund holdings is explained by these dummies. Fund type dummies explain a slightly higher, albeit still small, percentage (11\%) of the variation in the top ten holdings across fund-year observations. The specification in column 3 includes family dummies. In this case, $46 \%$ of the variance in the number of holdings and $36 \%$ of the variance of top ten holdings across funds and over time are explained by these dummies, much greater percentages than those 
explained by fund type and year effects alone. The following three reported regressions include a combination of these three types of dummies: family dummies, fund type dummies, and year dummies. In all these cases, the R-squared is relatively high only when family dummies are included. Lastly, we report a specification with all dummies together (column 7). We observe only a slight increase in the R-squared in comparison to the other regressions with family dummies. Therefore, family effects indeed seem relevant to explain the portfolio decisions of mutual funds, affecting not only the number of stock holdings but also the allocation in the top holdings.

The importance of family effects raises the immediate question of what factors might be behind the observed patterns. To shed light on these family effects and in line with the organizational literature, we estimate similar regressions controlling for other variables believed to "fundamentally" affect the portfolio choices of mutual funds. In particular, we explore the relevance of family-level and fund-level variables. We relate the number of stock holdings and loadings on the top ten stocks to (i) the ability of funds to gather and process information within families (proxied by the number of managers, family expenses, and family size), (ii) variables related to the characteristics of funds and their managers that could also affect portfolio decisions (fund age, manager tenure, and fund type fixed effects), and (iii) family effects themselves, which capture any remaining attribute or practice at the family level. The first set of variables directly captures the extent to which costly information is a binding factor in driving portfolio decisions. The second set of variables is motivated by our findings in the previous sub-section on the relation of the commonality of portfolios and managers. As highlighted by Bertrand and Schoar (2003), managers themselves (through their investment "styles" for example) can play an important role in explaining corporate behavior.

The results are shown in Table 9, columns 1 to 5 for the number of stock holdings as the dependent variable and columns 6-10 for the percentage of net assets in the top ten holdings. ${ }^{31}$ Column 1 shows that the number of stocks is positively associated with the number of managers; however, the marginal effect is low. For example, funds with one manager hold on average 133 stocks, while funds with two managers hold 135 stocks,

\footnotetext{
${ }^{31}$ Appendix Table 3 reports regressions with fund-level variables, instead of family-level ones, to capture funds' ability to gather and process information. The results are qualitatively similar to the ones presented here.
} 
and funds with six managers hold 197 stocks. The number of managers has similar effects on the loadings on the top ten holdings, as shown in column 6 . That is, there is a significant negative correlation (less portfolio concentration) but small marginal effects to additional managers. In all other specifications, the number of managers enters as a single count variable. In columns 2 and 3, the regressions do not include family dummies but incorporate fund-level variables (the count variable on the number of managers, manager tenure, fund age, and fund type dummies) and family-level ones (family expenses and family size). The number of managers and family size are positively associated with the number of holdings, while expenses at the family level show a negative correlation. Although statistically significant, they explain only a small proportion of the variance of the number of stocks held by mutual funds, between $2 \%$ and $7 \%$ versus $46 \%$ explained by family dummies alone (as reported in the top panel of Table 8, column 3). Regarding the top ten holdings, reported in columns 7 and 8, fund-level characteristics are statistically significant: the count variable on the number of managers and fund age show a negative correlation with the percentage of net assets in the top ten holdings. However, similar to the findings on the number of portfolio holdings, these variables only explain about one third of what family dummies alone do (bottom panel of Table 8, column 3). In other words, although variables that capture the capacity of funds to gather and process information within families and variables related to the characteristics of funds and their managers that could affect portfolio decision are related to the portfolio choices of mutual funds, they only explain a fraction of what family dummies do. In fact, when family dummies are included in these regressions (last two specifications reported in Table 9), not only the R-squared increases significantly, but many of these fund-level and other family-level variables become statistically insignificant.

In sum, the results presented in Section 4 suggest that the apparent lack of international diversification in mutual fund portfolios cannot be explained by the lack of available instruments or information at the family level or by transaction costs. Instead, organizational factors seem important in explaining mutual fund international investments. In particular, funds do not appear to share information within families, especially if they have different managers. In fact, the evidence is consistent with managers within families competing with each other, which might partly explain the 
limited number of stocks across funds and the similarity in the number of holdings across funds with different investment scopes. Family effects are also an important driver of mutual fund portfolio choices, even after controlling for fund-specific and family-specific characteristics related to the ability to gather and process information and select portfolios. These family effects are likely to capture practices or norms by different mutual fund companies, which affect the incentives faced by the managers of each individual fund and eventually the portfolios they choose.

\section{Returns to Diversification}

We now analyze mutual fund returns to shed light on whether they can explain why global funds do not have a substantially larger number of holdings relative to specialized funds. The fact that global funds tend to hold fewer stocks in fewer countries within regions of exposure (compared to specialized funds in the same mutual fund family) might be explained by the lack of extra diversification gains (due to correlated returns) and/or by the desire of investors to minimize tail risk. We thus study if there are potential gains from further international diversification by global funds. We also test whether benchmark effects can justify the portfolio choice of global funds, since managers are generally evaluated on their performance relative to benchmark indexes. Finally, we investigate the existence of an insurance premium in the returns of global funds.

\section{A. Standard Portfolio Model: Mean-Variance Analysis}

To evaluate the potential cost of the apparent lack of diversification by global funds, we compare the returns of global funds to those of "simulated global funds." We construct one simulated global fund for each actual global fund, consisting of a portfolio of specialized funds (that belong to the same mutual fund family as the global fund) and the global fund itself. This is analogous to letting a global fund invest in a portfolio that replicates specialized fund holdings at any point in time. The portfolio weights on the specialized funds and the global fund itself, which define the simulated global fund, are obtained through mean-variance optimizations. The returns of the simulated global funds are compared to the returns of the actual global funds over the same period. This is a conservative exercise to evaluate the gains from international diversification since it does not use all stocks in the investment universe of global funds to construct alternative 
portfolios (which might include assets that are hard to reach, but could apparently yield substantially higher risk-adjusted returns); it only uses the stocks already chosen by specialized funds within the same family.

There is an important advantage in constructing these simulated global funds at the family level. The fact that at least one specialized fund is already holding an asset is an indication that they are within the subset of investable assets. That is, there are no clear restrictions to investing in those assets, so transaction costs should not be very high. Moreover, the fact that a specialized fund within the mutual fund family is investing in a stock is an indication that the mutual fund company has already paid for the potential costs of collecting and processing information related to that stock.

To perform the mean-variance analysis, consider that there is a global fund with an observed return history $G$, and there are also several specialized funds within the mutual fund family of the global fund with observed returns $S_{i}$. The global fund can invest anywhere in the world, including the assets held by specialized funds (with the exception of the U.S., if the global fund is a foreign fund), whereas specialized funds invest in specific regions. ${ }^{32}$ The simulated global fund is constructed as a portfolio $P$ that assigns non-negative weights to all specialized funds and to the global fund itself. This within mutual fund family exercise is isomorphic to allowing a global fund to invest in specialized funds within its mutual fund family. This portfolio $P$ is constructed such that it optimally maximizes risk-adjusted returns by either (i) minimizing its own variance and achieving at least the same expected return as the global fund itself or (ii) maximizing its expected returns conditional on not increasing return volatility (relative to the actual global fund).

In other words, we impose the following restrictions to construct the simulated global funds: (i) portfolios are constructed for each global fund using a combination of the fund itself and specialized funds within the same mutual fund family; (ii) only buy and hold strategies are considered (funds cannot be shorted); (iii) the performance evaluation is always conducted out-of-sample; (iv) the portfolio is optimized on a daily or weekly basis; and (v) a mean-variance framework is used.

\footnotetext{
${ }^{32}$ In the families analyzed here, there are no specialized funds with holdings exclusively in the U.S.
} 
The first optimization problem is set to minimize the variance of the returns of the simulated global fund, keeping the returns of the simulated global fund at least as large as those of the actual global fund. The exercise can be described as follows:

$$
\underset{x}{\operatorname{Min}} \operatorname{var}(P)=x^{\prime} \sum x
$$

such that

$$
\begin{gathered}
E(P) \geq E(G), \\
0 \leq x_{i} \leq 1, \\
\sum_{i} x_{i} \leq 1, \\
\text { and } \\
P=\left(1-\sum_{i} x_{i}\right) \cdot G+\sum_{i} x_{i} \cdot S_{i},
\end{gathered}
$$

where $x_{i}$ is the portfolio weight on the specialized fund $i$ within the mutual fund family of the global fund and $\sum$ in (2) is the covariance matrix of all mutual fund returns within the same family. Since the simulated global fund $P$ is evaluated out-of-sample, the portfolio shares are computed at time $t$ using all available information up to that time, and held for the next period, when the return of $P$ is computed. We are then able to compare the return of the simulated global fund $P$ with the return of the global fund $G$ over the same time period. Portfolio weights are actively re-optimized every period.

As an alternative exercise, we maximize expected returns, keeping the variance of the simulated global fund at most as large as that of the global fund itself. This strategy can be described as follows:

$$
\operatorname{Max}_{x} \mathrm{E}(P)
$$

such that

$$
\begin{gathered}
\operatorname{var}(P) \leq \operatorname{var}(G), \\
0 \leq x_{i} \leq 1, \\
\sum_{i} x_{i} \leq 1, \\
\text { and } \\
P=\left(1-\sum_{i} x_{i}\right) \cdot G+\sum_{i} x_{i} \cdot S_{i} .
\end{gathered}
$$

We perform these two exercises for several types of global funds: world funds, foreign funds, or pools of world or foreign funds. Pools of world (or foreign) funds exist when more than one fund in a mutual fund family is classified as a world (or foreign) 
fund and these funds have different objectives such as value, growth, or blend strategies. An important benefit of the exercises performed here is that they do not need to identify the exact stocks held by different mutual funds within a mutual fund family at every point in time. The only information needed is mutual fund returns over time and the investment scope. This allows us to extend the time horizon of the data to start in the late 1980s.

The summary statistics of the simulated and actual global funds are shown in two tables. Table 10 reports the results for simulated global funds constructed with the largest number of available specialized funds (the largest cross-section), called the "largest number of funds" simulation. This simulation includes all possible specialized funds for each family and adjusts the time series accordingly to use the sample available for all funds included in the simulation; however, it does not necessarily entail a very long time span due to data availability on mutual fund returns. Table 11 reports results that use instead only specialized funds that allow for estimations of simulated global funds with relatively long time series, called the "longest available sample" simulation. In particular, specialized funds are excluded from the simulations if they reduce the sample size by at least six months. Naturally, this longer time series come at the cost of having fewer specialized funds in the comparisons. On average, three specialized funds are excluded from these simulations if compared to the largest number of funds simulations, which leads to an increase on average of 44 months in the time span of the simulations.

Tables 10 and 11 present the following statistics based on daily and weekly data: the average annualized returns of the actual global funds and the simulated global funds, the average annualized difference in accumulated returns between each simulated global fund and the corresponding global fund, the standard deviation of returns, and the number of comparisons. ${ }^{33}$ Annualized differences in accumulated returns are calculated over the entire sample for each simulation. Averages across simulations are then computed. ${ }^{34}$ The tables report separately statistics for world funds, foreign funds, and a pool of world or foreign funds. Results are presented using daily and weekly (Wednesday) returns.

\footnotetext{
${ }^{33} \mathrm{We}$ also compute these tables at the family level to show the heterogeneity across mutual fund families. The results are reported in Appendix Tables 4A and 4B for the largest number of funds simulations, and in Appendix Tables 5A and 5B for the longest available sample simulations.

${ }^{34}$ Though not reported, for robustness purposes we also calculated these return differences at every point in time and then computed the averages within and across simulations. The results are qualitatively similar to those reported here.
} 
The top panels of Tables 10 and 11 report results based on minimizing variances using equation (2). Table 10 shows that simulated global funds yield on average annualized excess returns of 485 basis points per year relative to world funds, 403 basis points relative to foreign funds, and 455 basis points relative to the pool of world or foreign funds. Moreover, the daily standard deviations of the returns of the simulated global funds are also smaller than those of the global funds. For example, Table 10 shows that the standard deviation falls by eight basis points for world and foreign funds and seven basis points for the pool of world or foreign funds. The numbers might seem small, but they are reductions in the daily standard deviation of returns. The results hold when using weekly returns. For example, Table 10 shows that the simulated global funds yield on average 436 basis points more per year than actual global funds when considering all types of global funds. These increases in risk-adjusted expected returns suggest that there are potential gains from further international diversification for global funds, even if investing only in stocks held by other funds within the same mutual fund family.

Table 11 shows that the results are similar when using the simulations with the longest time span. For example, the average improvement in returns is 295 basis points per year and the improvement in the daily standard deviation of returns is seven basis points. The differences are smaller than the ones reported in Table 10 because fewer specialized funds are available when the longest available sample simulations are considered. In other words, there is less scope for improvement than in the previous case. Similar patterns arise for simulations based on weekly returns.

The bottom panels of Tables 10 and 11 report summary statistics of portfolios constructed based on maximizing expected returns while holding the variance constant, using equation (3). When considering the simulations with the greater number of specialized funds (Table 10), the improvement in annualized daily returns is 434 basis points for all types of global funds, whereas the daily standard deviation falls by five basis points. If the longest available sample simulations are considered, Table 11 shows that the improvement in daily returns is 302 basis points and the improvement in the daily standard deviation of returns is six basis points. When using weekly returns, larger differences are obtained; the improvement in returns are 552 and 355 basis points for the largest number of funds and the longest available sample simulations, respectively. 
In sum, the results from these simulations suggest that one can reject the hypothesis that there are no gains from further international diversification by holding more stocks within and across countries. In other words, the investment practices documented in the first part of the paper seem indeed to be restrictive. Although there is some heterogeneity in the results depending on the strategy used, the simulated global funds consistently yield higher returns and no greater volatility than the actual global funds, even when comparing funds within the same families. ${ }^{35,36}$

\section{B. Benchmarking through a Tracking-Error Model}

Next we consider a different optimization strategy since the objective of most mutual funds is not necessarily to minimize the variance given some expected return, or to maximize returns given some variance. In particular, the performance of mutual funds might actually be evaluated in comparison to benchmark indexes. Moreover, managers might be compensated according to this relative performance. Thus, portfolio decisions should incorporate these managerial incentives. Furthermore, different mutual funds might follow different investment goals. It is possible that some mutual funds follow more passively benchmark indexes while others are more active in seeking returns. Therefore, the difference in returns between the actual global funds and the simulated global funds could, in principle, be explained by different investment practices across global and specialized funds. We address these two related issues in this sub-section.

We first test whether benchmark effects are important in explaining the gains from further international diversification found in the previous exercise. For the case of the variance minimization, we modify the objective function to take into consideration a benchmark index. ${ }^{37}$ The benchmark is the appropriate MSCI index $(B)$, specific for each global fund as described in the Morningstar database or in the fund's website. Instead of minimizing the variance of the portfolio, we minimize the variance of the difference

\footnotetext{
${ }^{35}$ For robustness, we also perform these simulations with a more restricted sample. We use rolling windows of 240 business days. The results are robust to this change and are reported in Appendix Tables $6 \mathrm{~A}$ and $6 \mathrm{~B}$.

${ }^{36}$ These results are not driven by significant changes in the weights of the simulated global funds over time. The time series of the portfolio weights change smoothly and the simulated portfolios do not require large shifts in holdings, which could entail large transaction costs.

${ }^{37}$ This is analogous to what others in the literature do. See, for example, Roll (1992) and Chan, Karceski, and Lakonishok (1999).
} 
between the portfolio and the benchmark index. Thus, while the constraints for the minimization problem (2) remain the same, the following equation is now used:

$$
\operatorname{Min}_{x} \operatorname{var}(P-B) \text {. }
$$

For the maximization of expected returns, we replace the restriction on the variance of the simulated global fund. We impose that the variance of the difference between the simulated global fund and the benchmark index has to be at most the same as the variance of the difference between the global fund and the benchmark index. Thus,

$$
\operatorname{var}(P-B) \leq \operatorname{var}(G-B) \text {. }
$$

The results of these new simulations based on daily data are reported in Table 12 for the largest number of funds simulations, and in Table 13 for the longest sample available simulations. For simulations that minimize the variance of the portfolio, the results are similar to the ones reported in the previous section. For the largest number of funds simulations reported in the top panel of Table 12, the simulated global funds generate excess annualized returns of 343,379 , and 420 basis points when compared to world funds, foreign funds, and the pool of world or foreign funds, respectively. Improvements in the standard deviation are also observed. On average, the daily standard deviation falls five basis points. When the longest available sample simulations are considered, as reported in the top panel of Table 13, the results hold. Simulated global funds yield, on average, an excess annualized expected return of 282 basis points across the different simulations, and a daily standard deviation five basis points lower than global funds. When maximizing expected returns, the results are even stronger. Table 12 shows an improvement on average of 402 basis points in annualized daily returns across mutual fund families and of seven basis points in daily standard deviations. In Table 13, where fewer specialized funds are included in the portfolio simulations, the improvement in returns is 322 basis points, but reaches 494 basis points for the pool of world or foreign funds. The improvement in daily standard deviations is also large: eight basis points on average across mutual fund families. In sum, our results suggest that benchmark effects cannot explain the empirical evidence described above regarding the investment patterns of mutual funds. We find that, even within the same mutual fund family and accounting for benchmarking, global funds could obtain improvements in both risk and returns by further international diversification. 
To study whether global and specialized funds follow different types of investment strategies and are thus differently active, we compute entropy measures over time. That is, we calculate the similarity of mutual fund portfolios between any two consecutive years of mutual fund holdings. Importantly, we compute separate measures for each individual fund and then obtain medians for world funds, foreign funds, and specialized funds. The median entropy over time is $0.63,0.65$, and 0.66 for world funds, foreign funds, and specialized funds, respectively. Figure 8 shows that these measures are very stable over time and are not statistically different from each other, suggesting that stock turnover is not different across funds with different investment scopes. Similar results are obtained when considering only holdings in developing economies, as shown in the bottom panel of Figure 8. These results suggest that different types of funds do not have significantly different trading strategies since their portfolios behave similarly over time.

\section{Insurance Premium in the Global Fund Returns}

Another possible explanation for our results is the existence of an insurance premium in the returns of global funds, not explicitly captured in our mean-variance analysis. Global funds have the ability to shift their stock holdings across countries and regions, which is not an option for specialized funds. Thus, investors might be willing to pay for this extra flexibility by requiring lower risk-adjusted returns from global funds, since they might yield gains during turbulent times. In other words, global funds might be better suited than specialized funds to avoid large losses due to their ability to move away from troubled countries. We therefore evaluate whether global funds have indeed a better ability to minimize losses relative to specialized funds by comparing the returns of global funds and simulated global funds (composed of both global funds themselves and specialized funds).

We first analyze higher moments of the distribution of returns, which would be important if global funds were to minimize losses during bad times instead of following a standard mean-variance approach. In particular, we compare the skewness and kurtosis of global fund returns to those of simulated global fund returns obtained from the meanvariance exercise. The results based on daily data are reported in Table 14 for the largest number of funds simulations and Table 15 for the longest available sample simulations. 
We find that skewness and kurtosis of returns are similar between global and simulated global funds. For example, according to the largest number of funds (longest time series) simulations, the skewness of global fund returns is $-0.69(-0.81)$ whereas that of the simulated global funds is $-0.84(-0.94)$ or $-0.70(-0.74)$, depending on whether the variance is minimized or expected returns are maximized. The kurtosis of global funds is 10.69 for the largest number of funds simulation and 12.85 for the longest available sample simulation. The kurtosis of the simulated global funds is 10.04 (11.96) when the variance is minimized and 7.74 (8.60) when expected returns are maximized, using the largest number of funds (longest available sample) simulations. Overall, the evidence suggests that, despite the differences in the mean and variances reported above, higher moments of the distribution of returns are not considerably different across global funds and simulated global funds. If anything, the kurtosis estimates are lower for the simulated global funds than for global funds, indicating that global funds do not appear to be robust portfolios as their distribution of returns has fatter tails.

We now consider the ability of global funds to move away from turbulence-hit countries or regions, and thus actually avoid realized risks. Given the limited information on portfolio holdings at a high frequency, we focus the analysis on the incidence of negative returns during turbulent times. For instance, conditional on large negative returns on the MSCI Emerging Market Index (our proxy for turmoil periods), we compare the realized returns of both actual global funds and simulated global funds. ${ }^{38}$ The results reported in Table 16 show that their performances are typically not statistically different from each other. For example, the average return of global funds is $-3.42 \%$ per week (p.w.) when the MSCI Emerging Market Index falls more than $10 \%$ in one week, while the average return of the simulated global funds is $-3.45 \%(-3.70 \%)$ p.w. when minimizing the variance (maximizing expected returns) for the largest number of funds. Therefore, global funds do not seem to avoid large losses if compared to specialized funds. ${ }^{39}$

\footnotetext{
${ }^{38}$ The evidence reported here considers only weekly returns. The results are similar if monthly returns are analyzed. Results are available upon request.

${ }^{39}$ A shift of the simulated global funds towards actual global funds and away from specialized funds does not seem to be driving these results. Portfolio weights on actual global funds are generally stable in periods in which the MSCI Emerging Market Index falls significantly. Moreover, this stability in portfolio weights
} 
As an alternative, Table 17 shows the return differentials conditional on periods in which the simulated global funds perform poorly. In these situations, global funds yield slightly higher weekly returns, with differentials between $0.14 \%$ and $0.95 \%$ p.w., although these return differentials are not always statistically different from zero. Table 18 reports the results of a similar exercise that focuses on periods when global funds do not perform well. In this case, the simulated global funds perform significantly better than global funds. For example, when the return of global funds is less than $10 \%$ in one week, the simulated global funds yield an extra $2.65 \%$ p.w. when maximizing the expected return with the largest number of funds. If the longest available sample for variance minimization is considered, the difference in returns is $1.88 \%$ p.w.

\section{Conclusions}

Using a novel micro dataset of portfolio holdings of U.S. mutual funds, this paper studies how institutional investors diversify their portfolios across countries. This dataset allows us to analyze important aspects of international asset allocation, documenting new stylized facts and shedding new light on existing explanations of international portfolio allocation. In particular, we take advantage of the fact that mutual funds belong to families, each having several funds with different scopes for international investment. As the investment scope broadens, one would expect funds to hold more securities and to be better diversified internationally, to the extent that asset returns are not perfectly correlated. This feature of the mutual fund industry enables us to study to what extent organizational aspects and other factors are important for international asset allocation and whether the investment practices exploit the potential gains from international diversification.

We find that global funds have expanded substantially, giving investors more options to diversify risk internationally. However, regardless of their investment scope, mutual funds tend to invest in a relatively small number of countries and firms, in about 100 stocks. In fact, as their investment possibilities widen, mutual funds invest in fewer stocks and fewer countries within each region of exposure. Consistently, the number of

also suggests that such a portfolio shift is not behind the evidence related to the higher moments of the return distribution. 
stock holdings is similar across funds within mutual fund families. However, there is significant variability in the number of holdings across families.

Several conclusions can be drawn from the results in this paper. First, the results suggest that the restrictive investment practices of mutual funds are not driven by instrument availability or transaction costs, broadly understood as barriers to purchase securities. Mutual funds purchase only a very small fraction of the instruments available for investment. Moreover, specialized funds have already invested in a set of assets, which are also available to global funds, indicating that there are no clear restrictions to purchase them. Furthermore, neither specialized nor global fund holdings are very large relative to market capitalization. Therefore, the pattern of investment in few firms does not seem to be driven by fund size and funds might be able to expand their exposures, probably without incurring major trading costs.

Second, the evidence in this paper highlights the importance of organizational aspects to explain the investment choices of institutional investors and does not seem consistent with the idea that asset allocation is driven by lack of information at the family level. These organizational aspects seem to induce competition among managers within the same family and affect portfolio choices across funds. In particular, since we compare the potential diversification gains of investing in assets already held within the mutual fund family, one can argue that the cost of gathering and processing information has already been paid by someone in the family and that other mutual fund managers within the family could in principle access that information. However, the portfolios of mutual funds within families investing in the same region do not appear to be very similar, even though their similarity increases when funds share asset managers. Furthermore, there are strong family effects behind mutual fund investment practices; that is, the number of stocks held across fund types and the portfolio loadings are similar within mutual fund companies but different across them. These family effects are much more important than other factors (such as the number of managers working in the fund, fund age, manager tenure, expenses at the fund and family level, and fund or family size) considered to affect both the ease of gathering and processing information and portfolio allocations themselves. 
Third, the investment practices documented in this paper entail a cost in the sense that, according to a mean-variance framework, there are large potential gains from further international diversification. Global funds could gain substantially from further international diversification in risk-adjusted terms simply by replicating portfolios already held by other funds within the same company. Furthermore, it is not the case that global funds yield lower returns in exchange for lower tail risk, or that there is an insurance premium embedded in the returns of global funds. Namely, global funds do not appear to be better suited to avoid large losses given their ability to shift their stock holdings across countries and regions. In fact, the skewness and kurtosis of global funds are similar to those of portfolios of specialized funds.

The evidence presented in this paper points to significant challenges in the prospects for broad international diversification. To the extent that global funds continue to be large relative to specialized funds, the findings in this paper suggest that the forgone diversification gains can be significant. At the same time, many countries and firms might not be able to benefit from tapping international investors and might thus face higher financing costs. These implications suggest that recent findings in the literature, such as an increase in the extent of international diversification (or a decline in home bias), might still require more analysis.

Several other puzzling aspects remain for future research, in particular in light of the seemingly important effects of organizational aspects on international diversification. Given the potential gains from investing across countries, why are global funds not more internationally diversified? Perhaps there are limits to the number of stocks that each manager can follow, determined by their own capacity to manage many more than 100 stocks and the investment practices and tools that each mutual fund family adopts. It also seems difficult for global fund managers to expand their holdings by relying on specialized fund managers. Moreover, it is possible that the remuneration schemes give no incentives for the information gathered by specialized funds to be freely shared within each mutual fund company, with each fund manager collecting her own information and competing with other managers. However, why do mutual fund families not establish funds of funds, mainly constructing portfolios based on specialized funds? Mutual fund families might have few incentives to do so because it could undermine the growth of 
their global funds, which are the ones that have expanded substantially over the years and generated large revenues. Alternatively, given the differences in the performance of specialized funds relative to global funds, why do investors not arbitrage these differences and favor specialized funds over global ones? What are the limits to arbitrage? Also, why are family effects so important? Organizational aspects of mutual fund companies seem to be behind these effects. But what specific factors make funds within families hold a similar number of stocks? Furthermore, what are the costs of the organizational practices? Our findings on the unexploited gains from international diversification might provide a rough, first lower-bound estimate of the welfare costs implied by mutual fund organizational norms. Finally, do global funds provide diversification benefits not captured by the mean-variance and other analyses performed in this paper? 


\section{References}

Aviat, A. and N. Coeurdacier, 2007. The Geography of Trade in Goods and Asset Holdings, Journal of International Economics 71 (1), 22-51.

Baily, M., C. Hulten, D. Campbell, T. Bresnahan, and R. Caves, 1992. Productivity Dynamics in Manufacturing Plants, Brookings Papers on Economic Activity, 187267.

Bartelsman, E. and M. Doms, 2000. Understanding Productivity: Lessons from Longitudinal Microdata, Journal of Economic Literature 38 (3), 569-594.

Bebchuk, L. and L. Stole, 1993. Do Short-Term Objectives Lead to Under- or Overinvestment in Long-Term Projects? Journal of Finance 48 (2), 719-729.

Bekaert, G. and C. Harvey, 2000. Foreign Speculators and Emerging Equity Markets, Journal of Finance 55 (2), 565-613.

Bertrand, M. and A. Schoar, 2003. Managing with Style: The Effect of Managers on Firm Policies, Quarterly Journal of Economics 118 (4), 1169-1208.

Black, S., and L. Lynch, 2001. How to Compete: The Impact of Workplace Practices and Information Technology on Productivity, Review of Economics and Statistics, 83 (3), 434-445.

Bloom, N., and J. Van Reenen, 2007. Measuring and Explaining Management Practices across Firms and Countries, Quarterly Journal of Economics, 122 (4), 1351-1408.

Bolton, P., X. Freixas, and J. Shapiro, 2004. Conflicts of Interest, Information Provision and Competition in the Financial Services Industry, Journal of Financial Economics 85 (2), 297-330.

Brennan, M. and H. Cao, 1997. International Portfolio Investment Flows, Journal of Finance 52 (5), 1851-1880.

Broner, F., R. G. Gelos, and C. Reinhart, 2006. When in Peril, Retrench - Testing the Portfolio Channel of Contagion, Journal of International Economics 69 (1), 203230.

Brown, K., W. Harlow, and L. Starks, 1996. Of Tournaments and Temptations: An Analysis of Managerial Incentives in the Mutual Fund Industry, Journal of Finance 51 (1), 85-110.

Cai, F. and F. Warnock, 2006. International Diversification at Home and Abroad, NBER Working Paper 12220.

Carhart, M., 1997. On Persistence in Mutual Fund Performance, Journal of Finance 52 (1), 57-82.

Chan, K., V. Covrig, and L. Ng, 2005. What Determines the Domestic Bias and Foreign Bias? Evidence from Mutual Fund Equity Allocations Worldwide, Journal of Finance 60 (3), 1495-1534.

Chan, L., J. Karceski, and J. Lakonishok, 1999. On Portfolio Optimization: Forecasting Covariances and Choosing the Risk Model, Review of Financial Studies 12 (5), 937-974.

Chevalier, J. and G. Ellison, 1997. Risk Taking by Mutual Funds as a Response to Incentives, Journal of Political Economy 105 (6), 1167-1200.

Chevalier, J. and G. Ellison, 1999. Career Concerns of Mutual Fund Managers, Quarterly Journal of Economics 114 (2), 389-432. 
Choe, H., B. C. Kho, and R. Stulz, 1999. Do Foreign Investors Destabilize Stock Markets? The Korean Experience in 1997, Journal of Financial Economics 54 (2), 227-264.

Cohen, M. and P. Bacdayan, 1994. Organizational Routines Are Stored as Procedural Memory: Evidence from a Laboratory Study, Organization Science, 5 (4), 554568.

Csaszar, F., 2009. Organizational Structure as a Determinant of Performance: Evidence from Mutual Funds, mimeo, INSEAD.

Dahlquist, M. and G. Robertsson, 2001. Direct Foreign Ownership, Institutional Investors, and Firm Characteristics, Journal of Financial Economics 59 (3), 413440.

Daude, C. and M. Fratzscher, 2008. The Pecking Order of Cross-Border Investment, Journal of International Economics 74 (1), 94-119.

De Roon, F., T. Nijman, and B. Werker, 2001. Testing for Mean-Variance Spanning with Short Sales Constraints and Transaction Costs: the Case of Emerging Markets, Journal of Finance 56 (2), 721-742.

De Santis, G. and B. Gerard, 1997. International Asset Pricing and Portfolio Diversification with Time-Varying Risk, Journal of Finance 52 (5), 1881-1912.

Dow, J. and G. Gorton, 1997. Noise Trading, Delegated Portfolio Management, and Economic Welfare, Journal of Political Economy 105 (5), 1024-1050.

Driessen, J. and L. Laeven, 2007. International Portfolio Diversification Benefits: CrossCountry Evidence from a Local Perspective, Journal of Banking and Finance 31 (6), 1693-1712.

Edison, H. and F. Warnock, 2004. U.S. Investors' Emerging Market Equity Portfolios: A Security-Level Analysis, Review of Economics and Statistics 86 (3), 691-704.

Errunza, V., K. Hogan, and M. Hung, 1999. Can the Gains from International Diversification Be Achieved without Trading Abroad? Journal of Finance 54 (6), 2075-2107.

Eun, C., W. Huang, and S. Lai, 2008. International Diversification with Large- and Small-Cap Stocks, Journal of Financial and Quantitative Analysis 43 (2), 489524.

Evans, J. and S. Archer, 1968. Diversification and the Reduction of Dispersion: An Empirical Analysis, Journal of Finance 23 (5), 761-767.

French, K., and J. Poterba, 1991. International Diversification and International Equity Markets, American Economic Review 81 (2), 222-226.

Gaspar, J. M., M. Massa, and P. Matos, 2006. Favoritism in Mutual-Fund Families? Evidence on Strategic Cross-Fund Subsidization, Journal of Finance 61 (1), 73104.

Gelos, R. G. and S. J. Wei, 2005. Transparency and International Portfolio Holdings, Journal of Finance 60 (6), 2987-3020.

Gibbons, R. and R. Henderson, 2010. Relational Contracts and the Origins of Organizational Capabilities, in Handbook of Organizational Economics, R. Gibbons and J. Roberts (eds.), Princeton University Press, forthcoming.

Goetzmann, W., L. Li, and K. G. Rouwenhorst, 2005. Long-Term Global Market Correlations, Journal of Business 78 (1), 1-38. 
Gozzi, J.C., R. Levine, and S. Schmukler, 2008. Internationalization and the Evolution of Corporate Valuation, Journal of Financial Economics, 88 (3), 607-632.

Griliches, Z., 1986. Productivity, R and D, and Basic Research at the Firm Level in the 1970's, American Economic Review 76 (1), 141-154.

Griliches, Z. and J. Mairesse, 1983. Comparing Productivity Growth: An Exploration of French and U.S. Industrial and Firm Data, European Economic Review 21 (1-2), 89-119.

Grinblatt, M. and M. Keloharju, 2001. How Distance, Language, and Culture Influence Stockholdings and Trades, Journal of Finance 56 (3), 1053-1073.

Grinblatt, M. and S. Titman, 1992. The Persistence of Mutual Fund Performance, Journal of Finance 47 (5), 1977-1984.

Grinblatt, M., S. Titman, and R. Wermers, 1995. Momentum Investment Strategies, Portfolio Performance and Herding: A Study of Mutual Fund Behavior, American Economic Review 85 (5), 1088-1105.

Grubel, H., 1968. Internationally Diversified Portfolios: Welfare Gains and Capital Flows, American Economic Review 58 (5), 1299-1314.

Harvey, C., 1995. Predictable Risk and Returns in Emerging Markets, Review of Financial Studies 8 (3), 773-816.

Hau, H. and H. Rey, 2008. Home Bias at the Fund Level, American Economic Review 98 (2), 333-338.

Henderson, R. and I. Cockburn, 1994. Measuring Competence? Exploring Firm Effects in Pharmaceutical Research, Strategic Management Journal 15, Winter, 63-84.

Henderson, R. and I. Cockburn, 1996. Scale, Scope, and Spillovers: The Determinants of Research Productivity in Drug Discovery, Rand Journal of Economics 27 (1), 3259.

Hong, H., J. Kubik, and J. Stein, 2005. Thy Neighbor's Portfolio: Word-of-Mouth Effects in the Holdings and Trades of Money Managers, Journal of Finance 60 (6), 28012824.

Ichniowski, C., K. Shaw, and G. Prennushi, 1997. The Effects of Human Resource Management Practices on Productivity: A Study of Steel Finishing Lines, American Economic Review 87 (3), 291-313.

Jegadeesh, N. and S. Titman, 1993. Returns to Buying Winners and Selling Losers: Implications for Stock Market Efficiency, Journal of Finance 48 (1), 65-91.

Kaminsky, G., R. Lyons, and S. Schmukler, 2004. Managers, Investors, and Crises: Mutual Fund Strategies in Emerging Markets, Journal of International Economics 64 (1), 113-134.

Kang, J. K. and R. Stulz, 1997. Why Is There a Home Bias? An Analysis of Foreign Portfolio Equity Ownership in Japan, Journal of Financial Economics 46 (1), 328.

Kempf, A. and S. Ruenzi, 2008. Tournaments in Mutual-Fund Families, Review of Financial Studies 21 (2), 1013-1036.

Kim, W. and S. J. Wei, 2002. Foreign Portfolio Investors Before and During a Crisis, Journal of International Economics 56 (1), 77-96.

Klette, T., 1999. Market Power, Scale Economies and Productivity: Estimates from a Panel of Establishment Data, Journal of Industrial Economics 47 (4), 451-476. 
Kose, M. A., E. Prasad, K. Rogoff, and S. J. Wei, 2009. Financial Globalization: A Reappraisal, IMF Staff Papers 56 (1), 8-62.

Kraay, A., N. Loayza, L. Serven, and J. Ventura, 2005. Country Portfolios, Journal of the European Economic Association 3 (4), 914-945.

Lafontaine, F. and K. Shaw, 2005. Targeting Managerial Control: Evidence from Franchising, Rand Journal of Economics 36 (1), 131-150.

Lane, P. and G. M. Milesi-Ferretti, 2008. International Investment Patterns, Review of Economics and Statistics 90 (3), 538-549.

Montgomery, C., and B. Wernerfelt, 1988. Diversification, Ricardian Rents, and Tobin's Q, Rand Journal of Economics 19 (4), 623-632.

Nanda, V., Z. Wang, and L. Zheng, 2004. Family Values and the Star Phenomenon: Strategies of Mutual-Fund Families, Review of Financial Studies 17 (3), 667-698.

Nelson, R. and S. Winter, 2002. Evolutionary Theorizing in Economics, Journal of Economic Perspectives 16 (2), 23-46.

Obstfeld, M. and A. Taylor, 2004. Global Capital Markets: Integration, Crisis, and Growth, Cambridge University Press.

Pollet, J. and M. Wilson, 2008. How Does Size Affect Mutual Fund Behavior? Journal of Finance 63 (6), 2941-2969.

Portes, R. and H. Rey, 2005. The Determinants of Cross-Border Equity Flows, Journal of International Economics 65 (2), 269-296.

Rajan, R., 2006. Has Financial Development Made the World Riskier? European Financial Management 12 (4), 499-533.

Rajan, R. and L. Zingales, 1998. Financial Dependence and Growth, American Economic Review 88 (3), 559-586.

Roll, R., 1992. A Mean/Variance Analysis of Tracking Error, Journal of Portfolio Management, 18 (4), 13-22.

Shleifer, A. and R. Vishny, 1990. Equilibrium Short Horizons of Investors and Firms, American Economic Review 80 (2), 148-153.

Stein, J., 2005. Why Are Most Funds Open-End? Competition and the Limits of Arbitrage, Quarterly Journal of Economics 120 (1), 247-272.

Strong, N. and X. Xu, 2003. Understanding the Equity Home Bias: Evidence from Survey Data, Review of Economics and Statistics 85 (2), 307-312.

Stulz, R., 1999. Globalization, Corporate Finance, and the Cost of Capital, Journal of Applied Corporate Finance 12 (3), 8-25.

Stulz, R., 2005. The Limits of Financial Globalization, Journal of Finance 60 (4), 15951638.

Tesar, L. and I. Werner, 1995. Home Bias and High Turnover, Journal of International Money and Finance 14 (4), 467-492.

Van Wincoop, E., 1999. How Big Are Potential Welfare Gains from International Risksharing? Journal of International Economics 47 (1), 109-135.

Wermers, R., 1999. Mutual Fund Herding and the Impact on Stock Prices, Journal of Finance 54 (2), 581-622. 
Figure 1. Stylized Structure of U.S. Mutual Fund Families

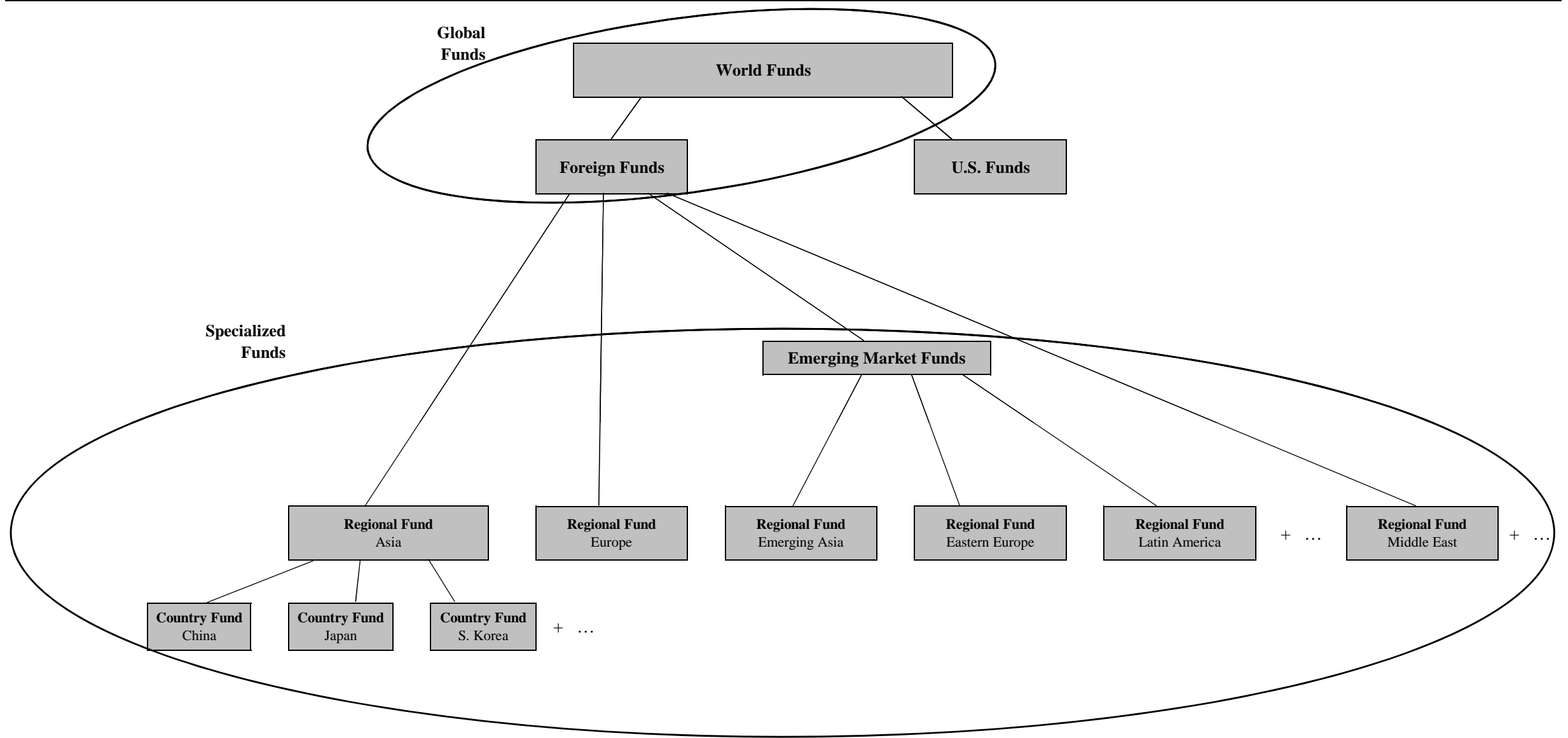

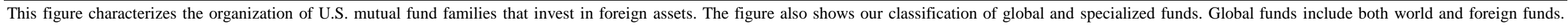
Specialized funds include: emerging market funds, regional funds, and country funds. The names used to characterize the specialized funds are just examples. 
Figure 2. Total Number of Funds and Total Assets under Management by Fund Type

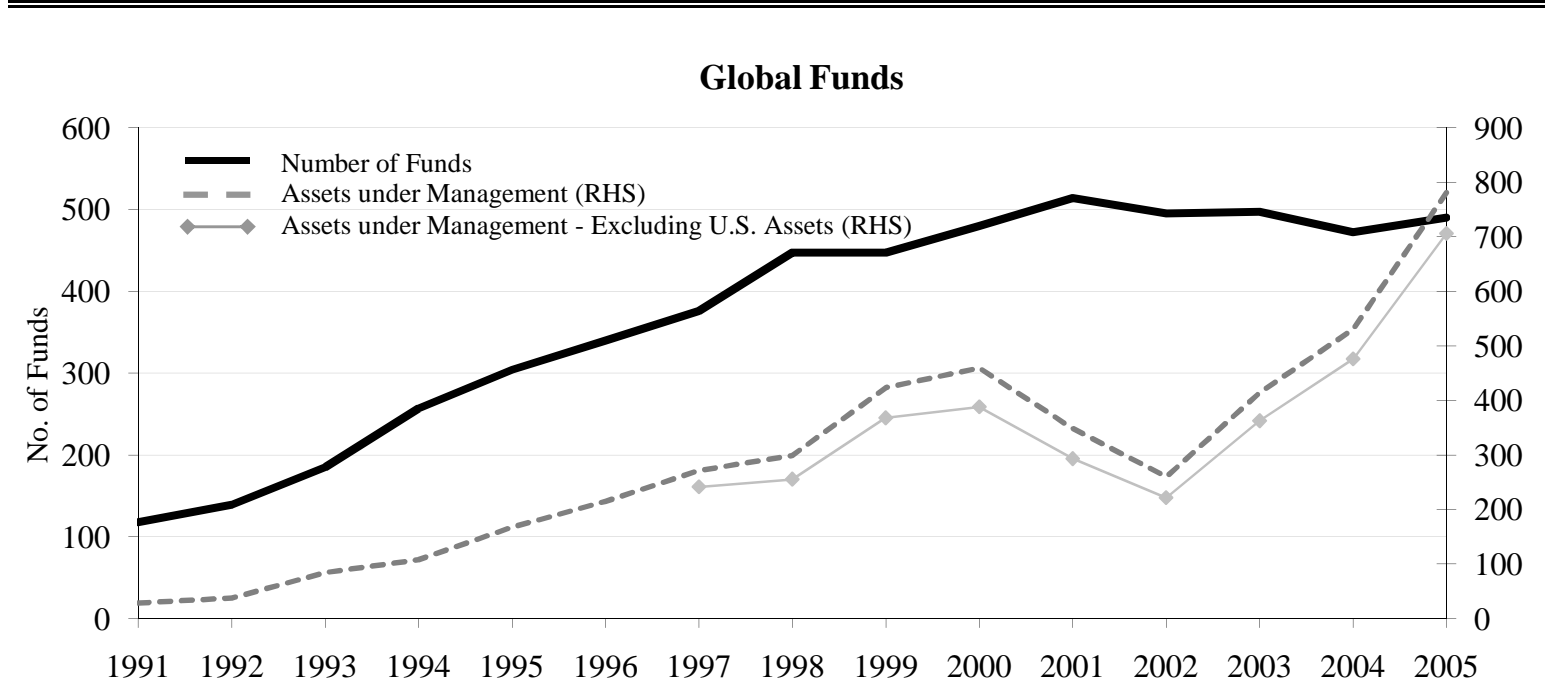

\section{Specialized Funds}

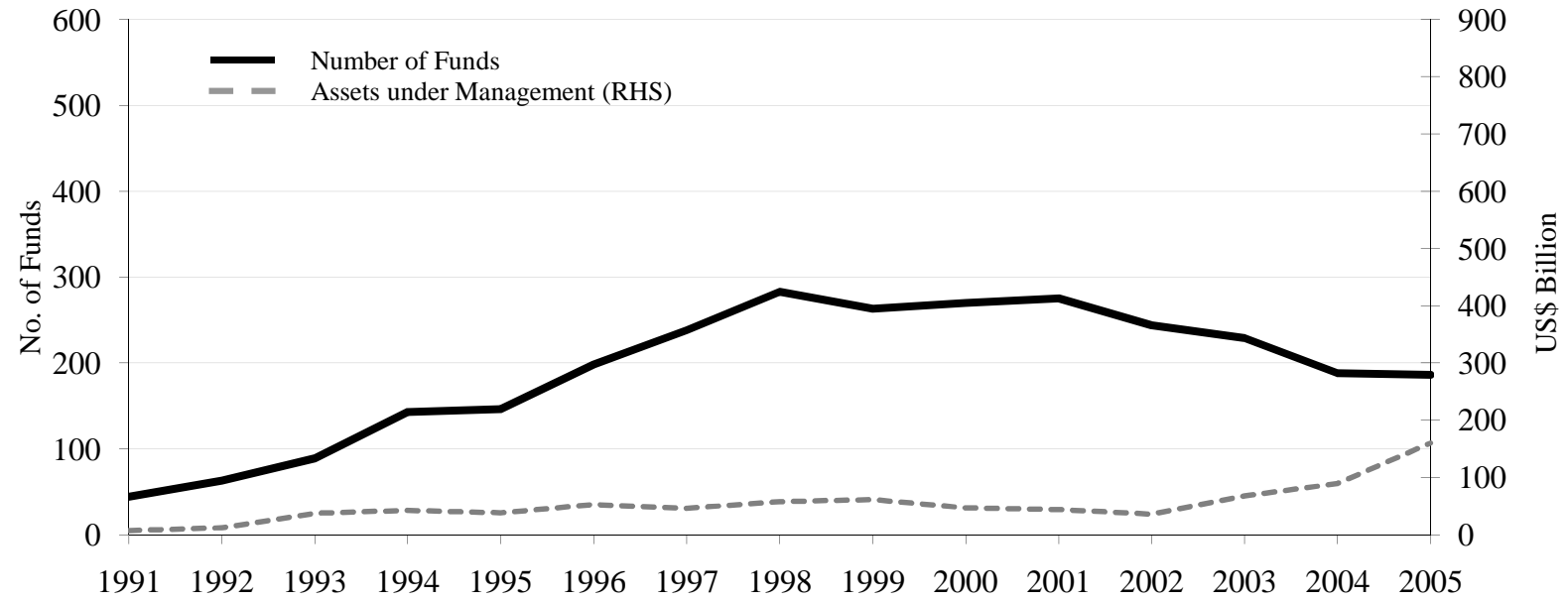

This figure shows the total number of mutual funds in our holdings database and their total assets under management by fund type from 1991 to 2005. For global funds, the value of assets under management invested in non-U.S. assets is also shown (starting in 1997 due to data availability). Data on assets under management are in billions of U.S. dollars. Global funds include both world funds and foreign funds. Specialized funds include: emerging market funds, regional funds, and country funds. 

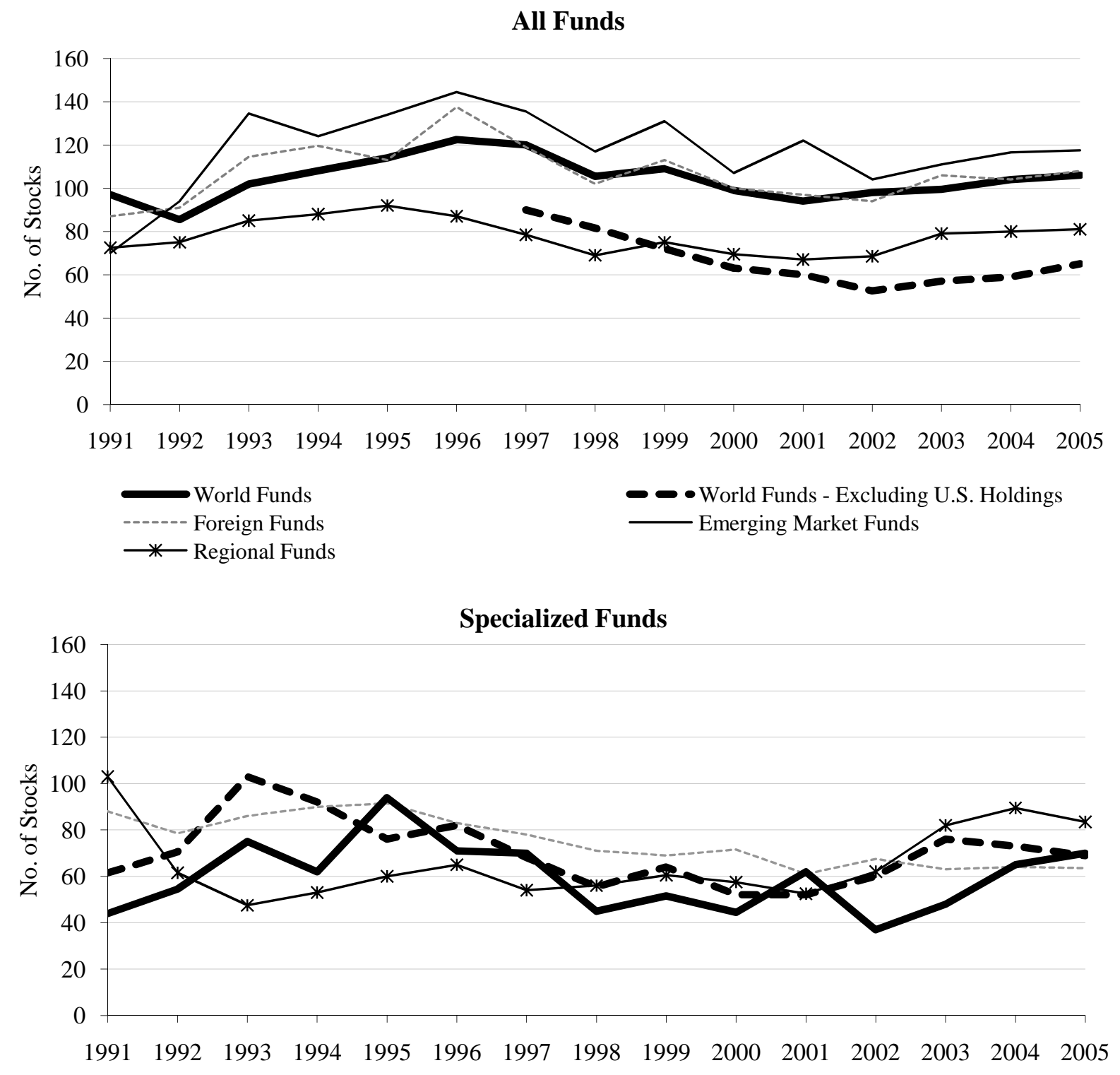

- - Asia Funds ------ Europe Funds $\longrightarrow$ Latin America Funds — Country Funds

This figure shows the median number of stock holdings by mutual fund type from 1991 to 2005. The top panel includes world funds, foreign funds, emerging market funds, and regional funds. The median number of nonU.S. holdings for world funds is also shown (starting in 1997 due to data availability). The bottom panel includes the following specialized funds: Asia funds, Europe funds, Latin America funds, and country funds. 
Figure 4. Mutual Fund Holdings as a Proportion of the Total Number of Listed Stocks by Country

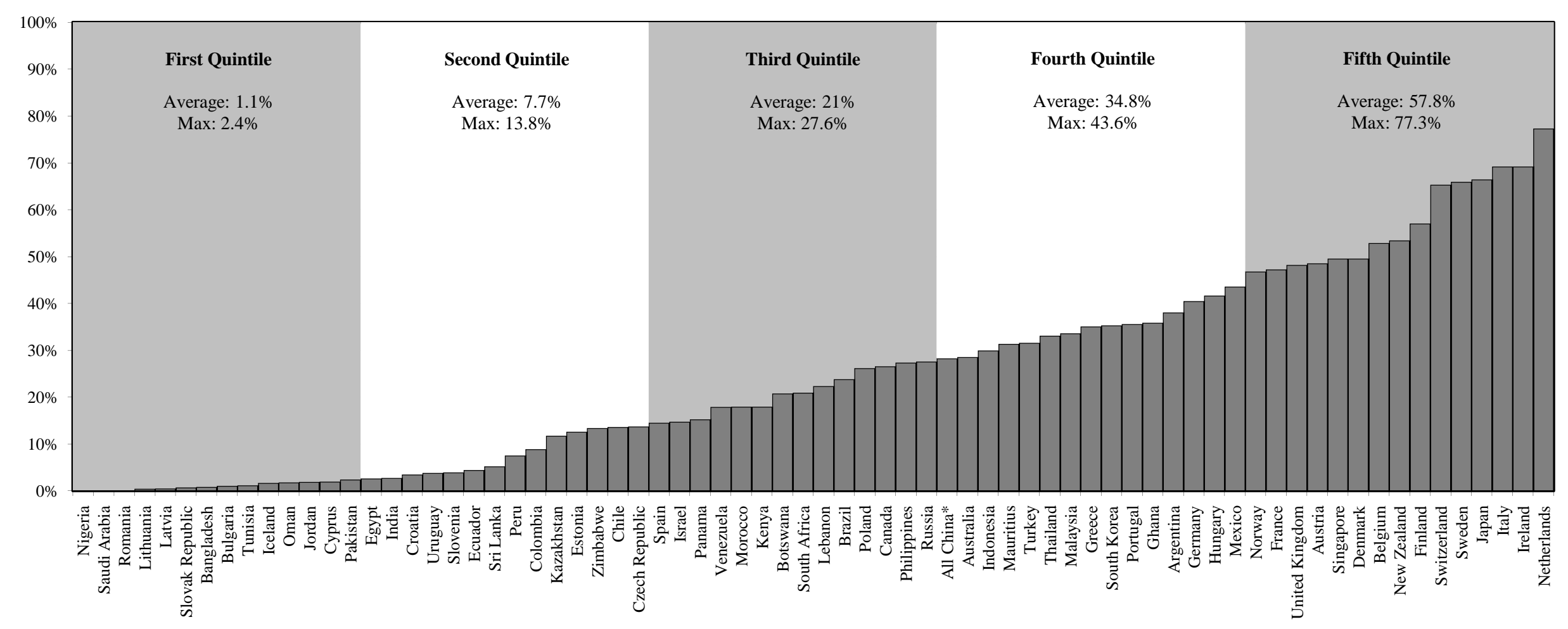

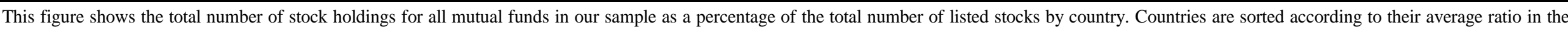

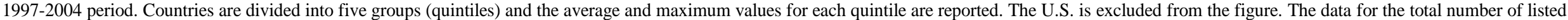
stocks come from the Global Financial Database. * "All China" includes the following economies: Mainland China, Hong Kong, and Taiwan. 
Figure 5. Evolution of Entropy Measure

Total Holdings - Excluding U.S. Holdings

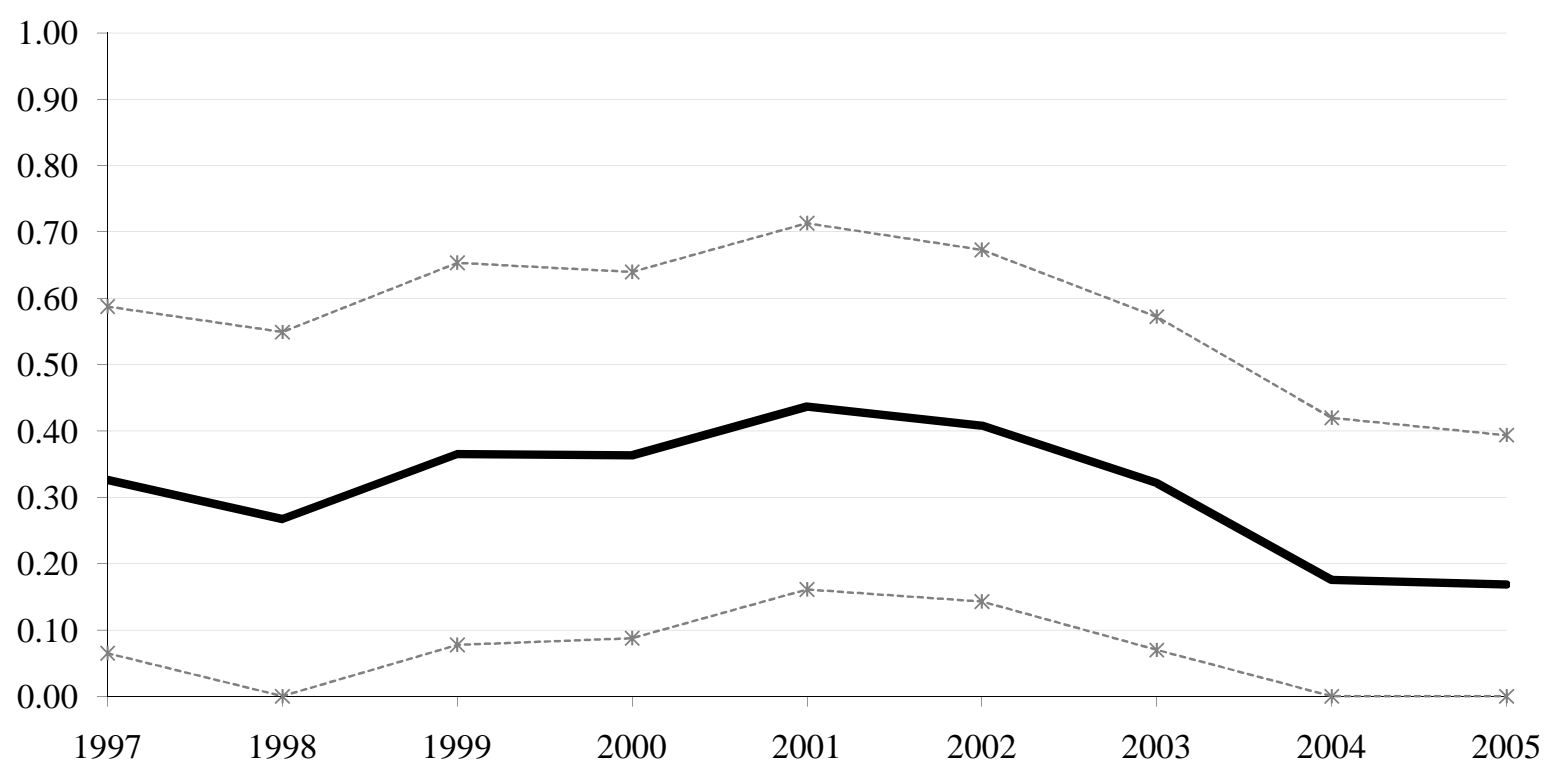

Holdings in Developing Countries Only

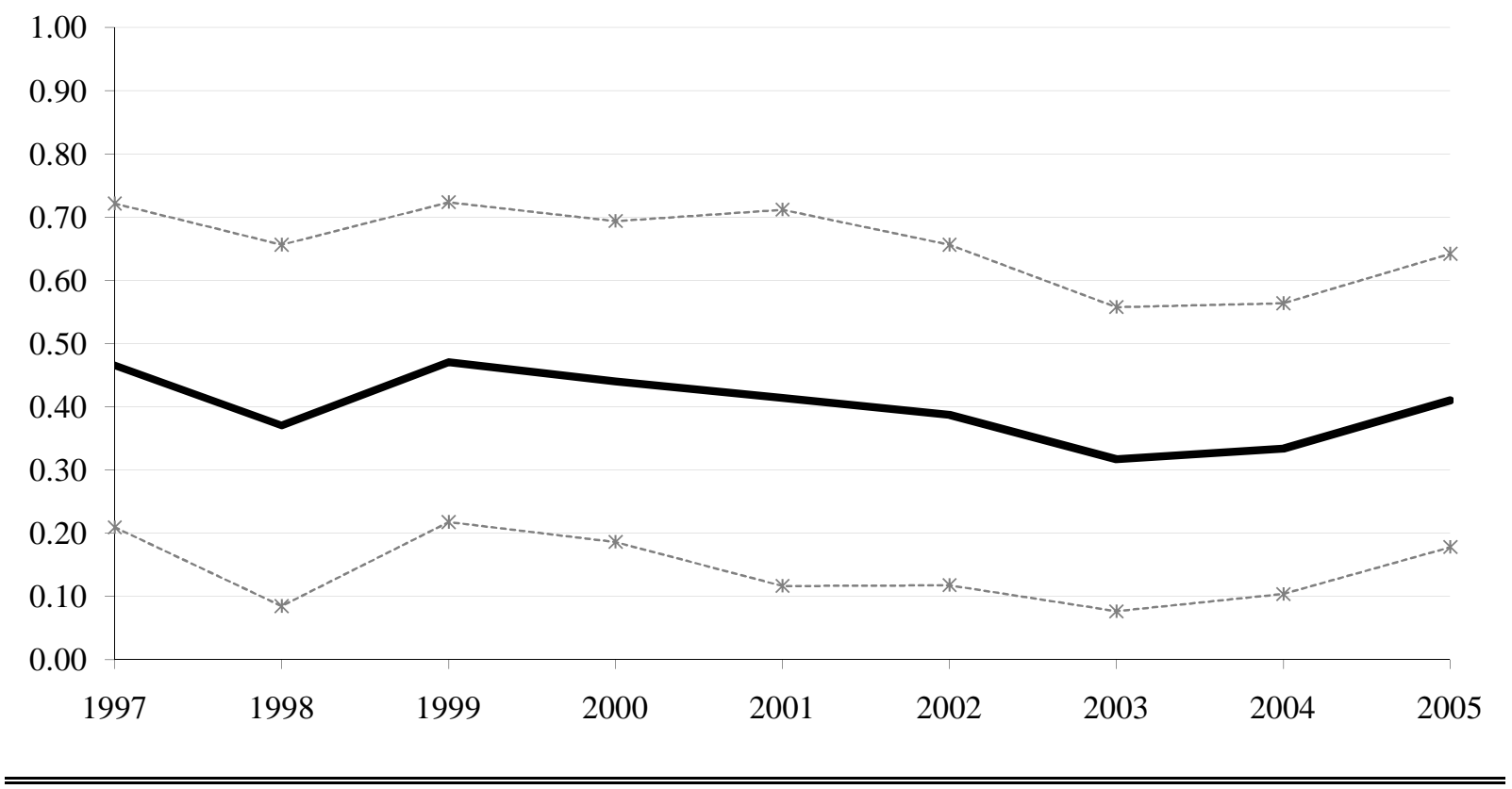

This figure shows the evolution of the entropy measure from 1997 to 2005. The entropy measure captures the commonality of stock holdings in the portfolios of global funds and specialized funds. The top panel includes stock holdings in all countries except the U.S. The bottom panel includes stock holdings in developing countries only. The thick line represents the median value across families in a given year. The dotted grey lines represent +/- one standard deviation from the median. Global funds include both world funds and foreign funds. Specialized funds include: emerging market funds, regional funds, and country funds. 
Figure 6. Evolution of Entropy Measure by Number of Common Managers

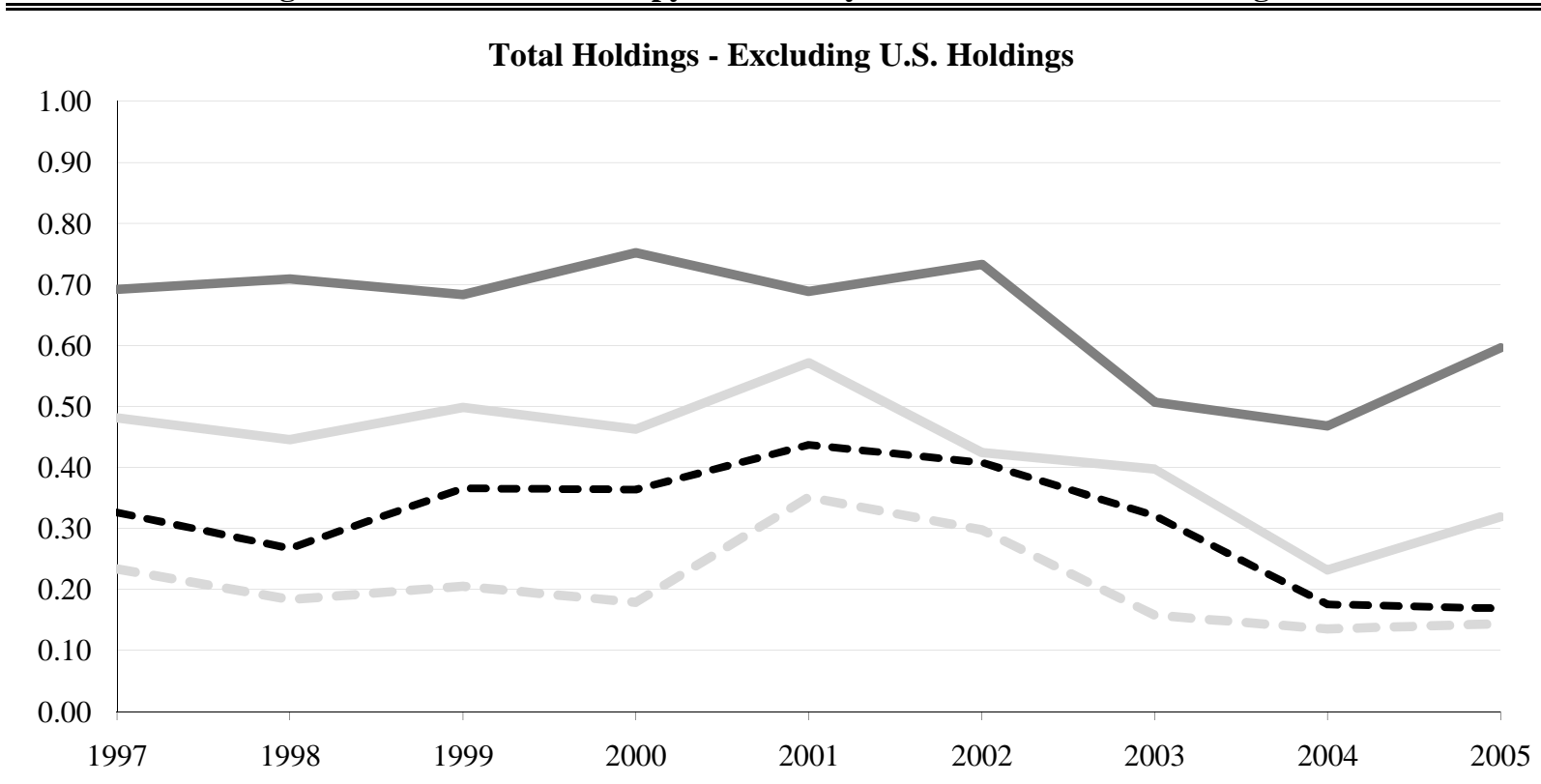

Holdings in Developing Countries Only

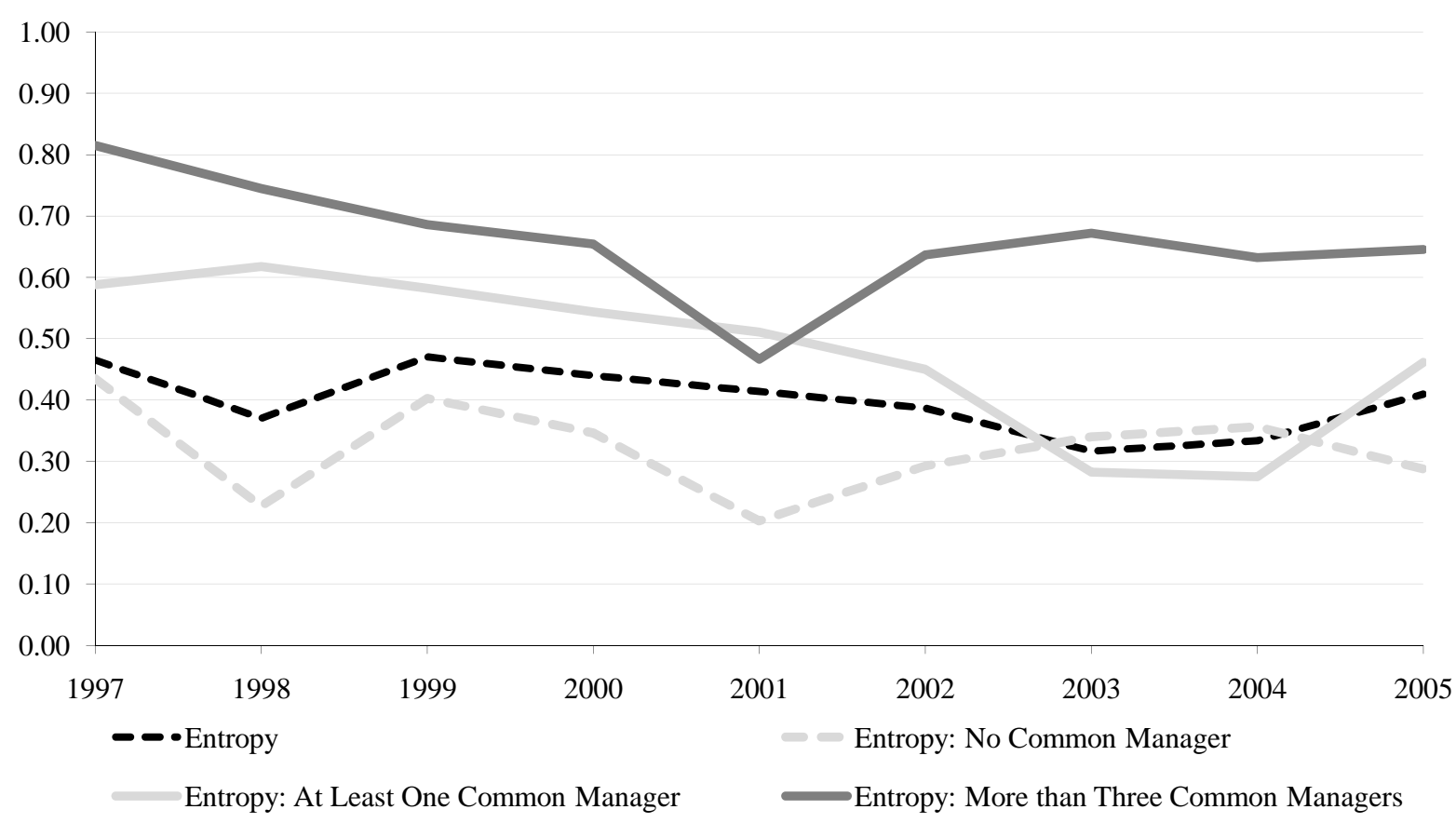

This figure shows the evolution of the entropy measure according to the number of common managers shared by global funds and specialized funds within mutual fund families from 1997 to 2005. The entropy measure captures the commonality of stock holdings in the portfolios of global funds and specialized funds. The entropy measure is reported for family-year observations in which funds share no managers, at least one common manager, and more than three common managers. The figure also reports the entropy measure by itself (black-dotted line), as reported in Figure 5. The figure reports the median value across families in a given year. The top panel includes stock holdings in all countries except the U.S. The bottom panel includes stock holdings in developing countries only. Global funds include both world funds and foreign funds. Specialized funds include: emerging market funds, regional funds, and country funds. 
Figure 7. Number of Holdings: Dispersion and Family Effects

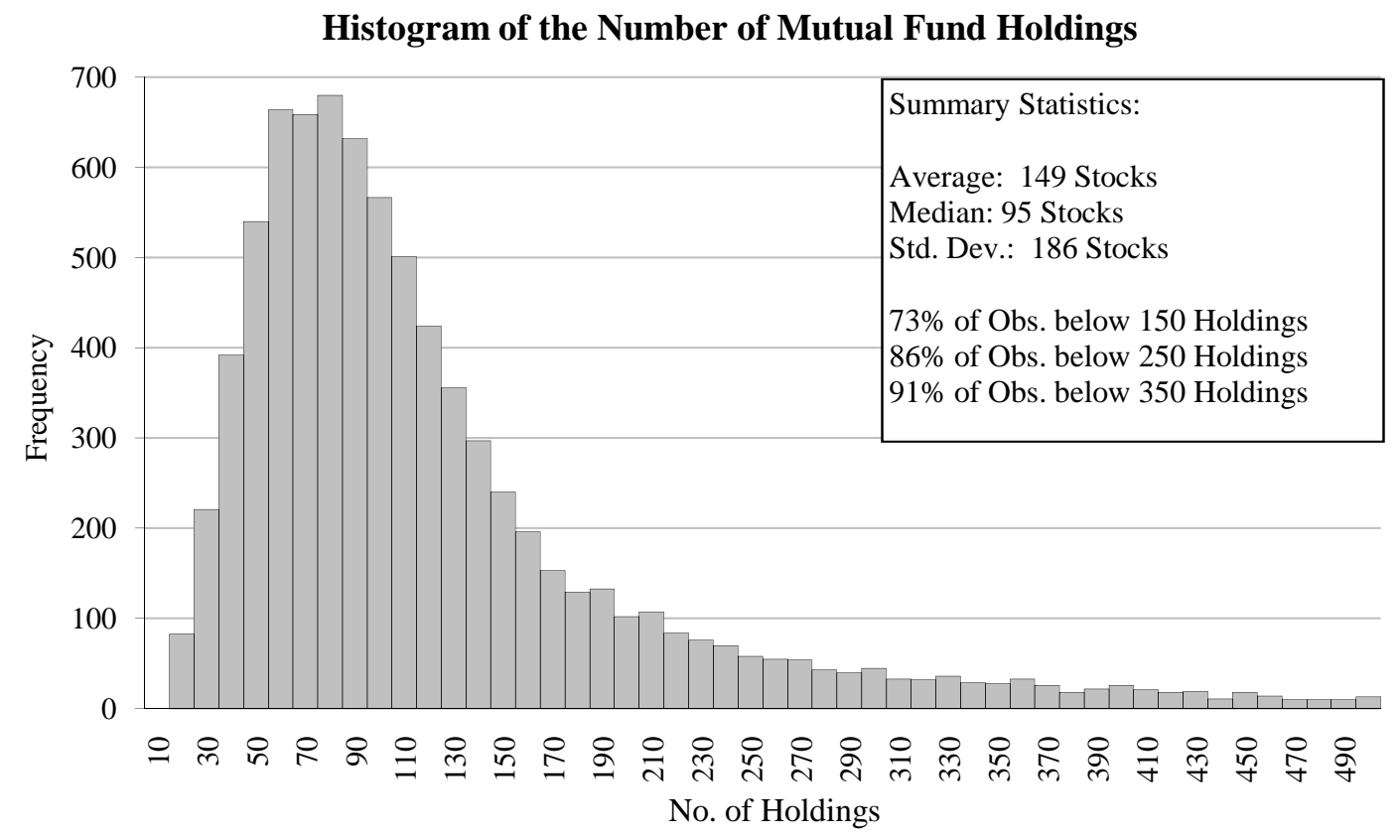

Median Number of Holdings by Mutual Fund Family

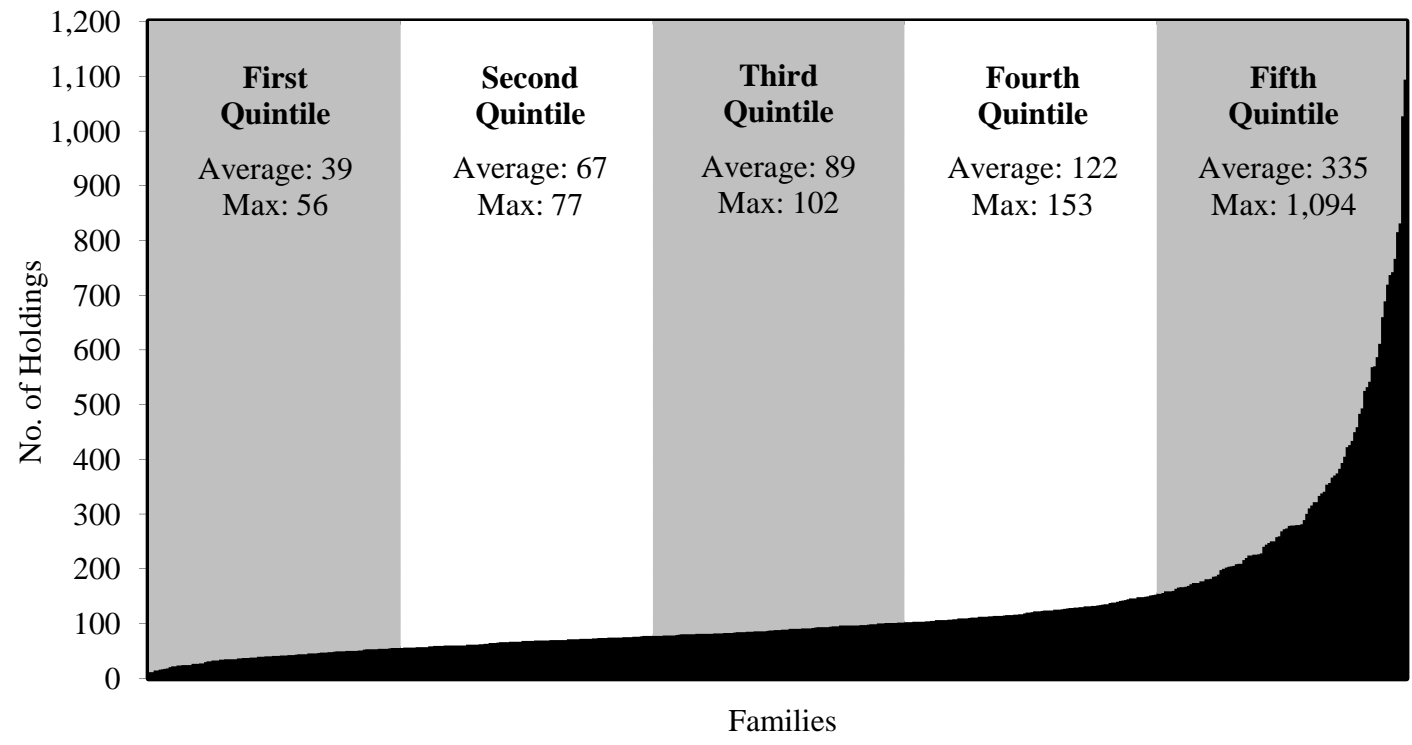

This figure shows the dispersion in the number of stock holdings by mutual funds and mutual fund families during the 1991-2005 period. The top panel shows a histogram with the distribution of the number of stock holdings for all mutual funds in our sample. The bottom panel reports the median number of stock holdings by mutual fund family. All funds in any given family are considered. Families are sorted according to their median number of stock holdings during the 1991-2005 period. Families are then divided into five groups (quintiles). The average and maximum values for each quintile are reported. 
Figure 8. Evolution of Within-Fund Entropy Measure

Total Holdings - Excluding U.S. Holdings

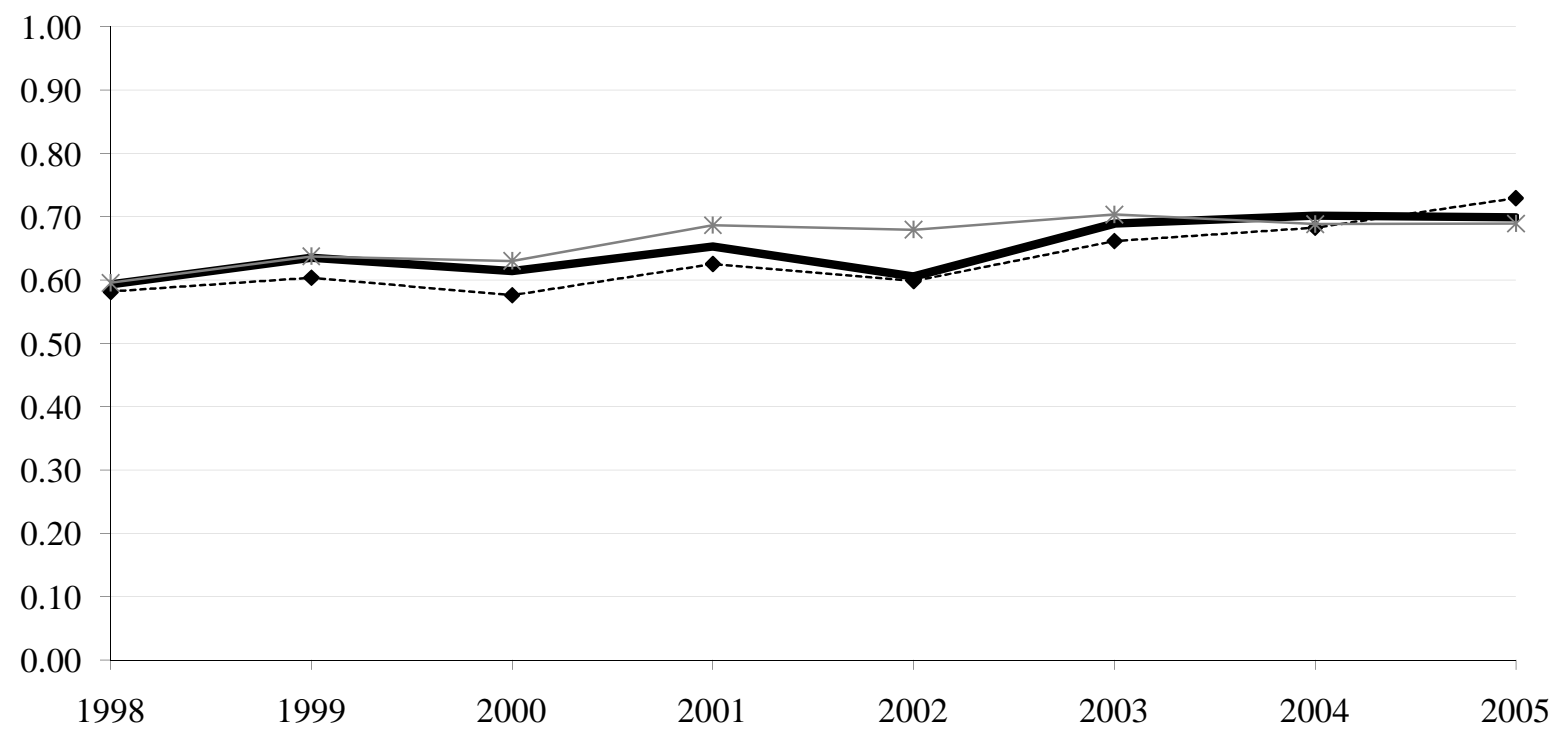

Holdings in Developing Countries Only

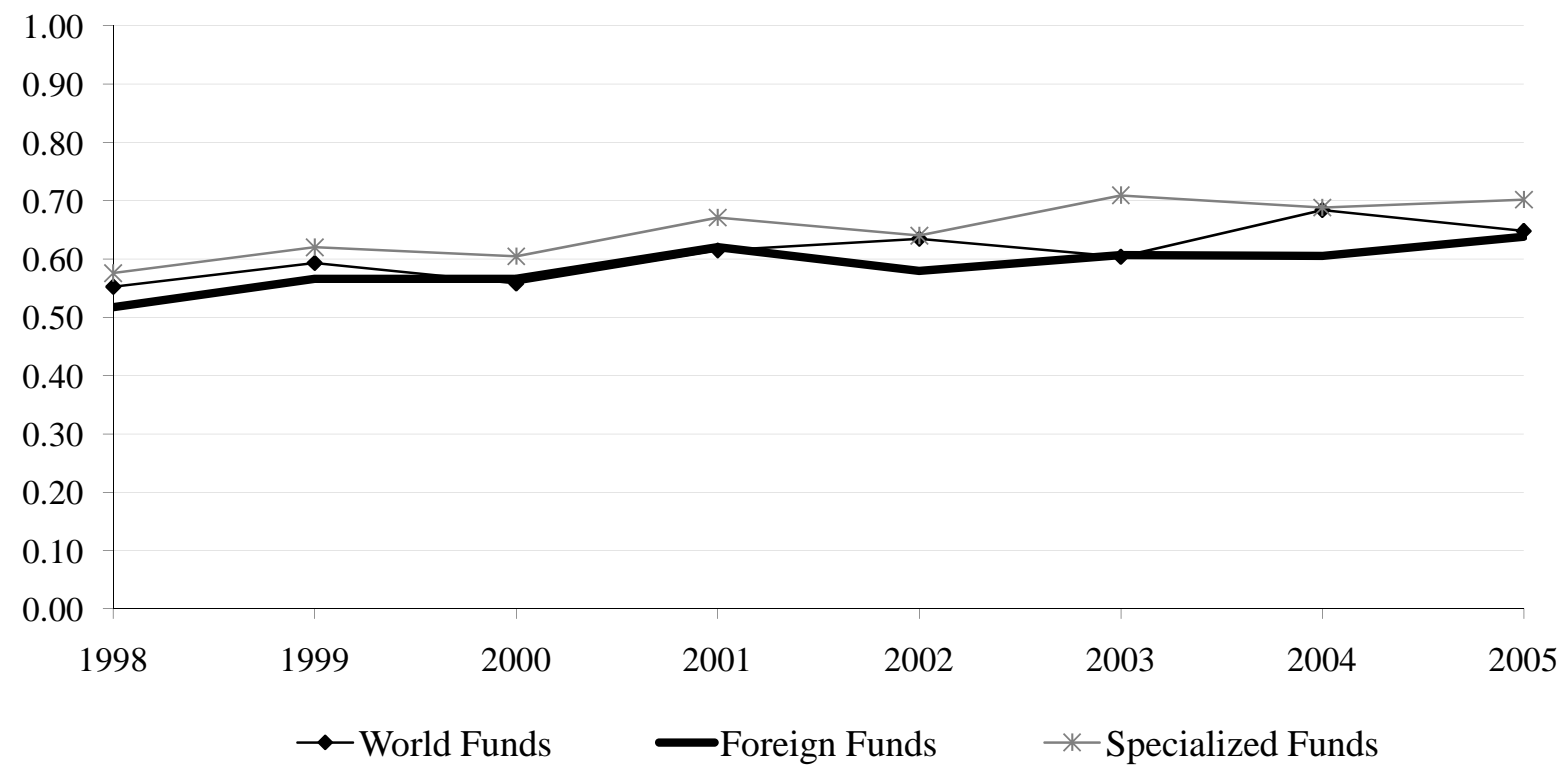

This figure shows the evolution of the within-fund entropy measure by fund type from 1997 to 2005. The within-fund entropy measure captures the commonality of stock holdings in two consecutive years for each individual mutual fund. The figure reports the median value across families in a given year. The top panel includes stock holdings in all countries except the U.S. The bottom panel includes stock holdings in developing countries only. Specialized funds include: emerging market funds, regional funds, and country funds. 
Table 1. Data Coverage

\begin{tabular}{|c|c|}
\hline \multicolumn{2}{|c|}{ Holdings Data } \\
\hline Sample & 1991-2005 \\
\hline Frequency & Annual \\
\hline Number of Families & 499 \\
\hline Total Number of Funds & 1,904 \\
\hline Total Number of Fund-Year Observations & 8,420 \\
\hline Total Number of Asset-Level Holdings & $1,359,750$ \\
\hline \multicolumn{2}{|c|}{ Price Data } \\
\hline Sample & September 1989 - June 2006 \\
\hline Frequency & Daily \\
\hline Number of Families & 36 \\
\hline Total Number of Funds & 371 \\
\hline Total Number of Observations & 722,885 \\
\hline
\end{tabular}


Table 2. Number of Mutual Fund Holdings

\begin{tabular}{|c|c|c|c|}
\hline & Average & Median & Std. Dev. \\
\hline \multicolumn{4}{|l|}{ Fund Type } \\
\hline Global Funds & 155 & 96 & 196 \\
\hline World Funds & 136 & 106 & 132 \\
\hline Excluding U.S. Holdings & 101 & 76 & 100 \\
\hline Foreign Funds & 175 & 105 & 219 \\
\hline Specialized Funds & 117 & 79 & 136 \\
\hline Emerging Market Funds & 161 & 121 & 138 \\
\hline Asia Funds & 89 & 65 & 110 \\
\hline Europe Funds & 111 & 71 & 158 \\
\hline Latin America Funds & 58 & 56 & 24 \\
\hline Country Funds & 126 & 63 & 178 \\
\hline All Funds & 150 & 95 & 186 \\
\hline
\end{tabular}


Table 3. Differences in Holdings within Regions by Fund Type

\begin{tabular}{|c|c|c|c|}
\hline \multirow[b]{2}{*}{ Fund Type } & \multicolumn{3}{|c|}{ Number of Holdings } \\
\hline & Asia & Developed Europe & Latin America \\
\hline \multicolumn{4}{|l|}{ Regional Funds } \\
\hline \multirow[t]{2}{*}{ Median Number of Holdings } & 60 & 62 & 41 \\
\hline & \multicolumn{3}{|c|}{$\begin{array}{l}\text { Drop in Holdings in Each Region by Fund Type } \\
\text { (In Percent, Relative to Regional Funds) }\end{array}$} \\
\hline Emerging Market Funds & $-33 \%$ & - & $-34 \%$ \\
\hline Foreign Funds & $-42 \%$ & $-5 \%$ & $-93 \%$ \\
\hline \multirow[t]{2}{*}{ World Funds } & $-69 \%$ & $-49 \%$ & $-94 \%$ \\
\hline & \multicolumn{3}{|c|}{ Number of Countries } \\
\hline Fund Type & Asia & Developed Europe & Latin America \\
\hline \multicolumn{4}{|l|}{ Regional Funds } \\
\hline \multirow[t]{2}{*}{ Median Number of Countries } & 8 & 12 & 6 \\
\hline & \multicolumn{3}{|c|}{$\begin{array}{l}\text { Drop in Countries in Each Region by Fund Type } \\
\text { (In Percent, Relative to Regional Funds) }\end{array}$} \\
\hline Emerging Market Funds & $-10 \%$ & - & $-17 \%$ \\
\hline Foreign Funds & $-30 \%$ & $0 \%$ & $-72 \%$ \\
\hline World Funds & $-36 \%$ & $-14 \%$ & $-75 \%$ \\
\hline
\end{tabular}

This table reports differences across fund types in regional stock and country holdings over the 1997-2005 period. The top panel shows the differences in the number of stock holdings across fund types. The bottom panel shows the differences in the number of countries receiving investments from different fund types. The first row in each panel reports the median number of stock or country holdings in a given region for the corresponding regional funds. Differences are then calculated as the percentage change of this median number of stock holdings of a fund relative to those of the corresponding regional fund. Comparisons are made within mutual fund families. Families without the corresponding regional funds are excluded from the analysis. 
Table 4. Mutual Fund Holdings

\begin{tabular}{|c|c|c|c|c|c|}
\hline & \multirow{2}{*}{$\begin{array}{c}\text { Number of } \\
\text { Listed } \\
\text { Companies }\end{array}$} & \multicolumn{2}{|c|}{ All Fund Holdings } & \multicolumn{2}{|c|}{ Global Fund Holdings } \\
\hline & & $\begin{array}{c}\text { Number of } \\
\text { Holdings }\end{array}$ & $\begin{array}{c}\text { As a Percentage of } \\
\text { All Listed Stocks } \\
\end{array}$ & $\begin{array}{c}\text { Number of } \\
\text { Holdings } \\
\end{array}$ & $\begin{array}{c}\text { As a Percentage of } \\
\text { All Listed Stocks } \\
\end{array}$ \\
\hline & \multicolumn{5}{|c|}{1997} \\
\hline Total & 30,319 & 9,086 & $30 \%$ & 6,267 & $21 \%$ \\
\hline Developed Countries & 12,987 & 6,815 & $52 \%$ & 4,953 & $38 \%$ \\
\hline Asia & 5,760 & 3,249 & $56 \%$ & 2,246 & $39 \%$ \\
\hline Europe & 6,392 & 3,459 & $54 \%$ & 2,635 & $41 \%$ \\
\hline Middle East & 802 & 87 & $11 \%$ & 54 & $7 \%$ \\
\hline Developing Countries & 17,332 & 2,271 & $13 \%$ & 1,314 & $8 \%$ \\
\hline Asia & 10,089 & 1,304 & $13 \%$ & 693 & $7 \%$ \\
\hline Europe & 2,697 & 319 & $12 \%$ & 167 & $6 \%$ \\
\hline Latin America & 2,196 & 399 & $18 \%$ & 297 & $14 \%$ \\
\hline \multirow[t]{2}{*}{ Middle East \& Africa } & 2,350 & 249 & $11 \%$ & 157 & $7 \%$ \\
\hline & \multicolumn{5}{|c|}{2004} \\
\hline Total & 39,061 & 6,289 & $16 \%$ & 5,510 & $14 \%$ \\
\hline Developed Countries & 18,282 & 5,204 & $28 \%$ & 4,799 & $26 \%$ \\
\hline Asia & 7,758 & 2,748 & $35 \%$ & 2,429 & $31 \%$ \\
\hline Europe & 9,817 & 2,392 & $24 \%$ & 2,315 & $24 \%$ \\
\hline Middle East & 686 & 45 & $7 \%$ & 37 & $5 \%$ \\
\hline Developing Countries & 20,779 & 1,085 & $5 \%$ & 711 & $3 \%$ \\
\hline Asia & 10,444 & 566 & $5 \%$ & 394 & $4 \%$ \\
\hline Europe & 6,279 & 184 & $3 \%$ & 114 & $2 \%$ \\
\hline Latin America & 1,525 & 195 & $13 \%$ & 141 & $9 \%$ \\
\hline Middle East \& Africa & 2,531 & 140 & $6 \%$ & 62 & $2 \%$ \\
\hline
\end{tabular}

This table shows the number of listed stocks and the number of stock holdings for mutual funds in developed and developing countries across selected regions. The top panel shows data for 1997; the bottom panel shows data for 2004. The first column shows the total number of listed stocks across the countries' main stock exchanges within each region. The second and third columns show the number of stock holdings for all U.S. equity mutual funds in these regions, in absolute terms and as a percentage of the universe of listed stocks. The fourth and fifth columns report the same numbers for global funds only. The data on stock listings come from the Global Financial Database. Stock holdings in the U.S. and offshore financial centers are excluded from the table. 
Table 5. Size of Mutual Fund Holdings

\begin{tabular}{|c|c|c|c|c|}
\hline \multirow[b]{3}{*}{ Fund Type } & \multicolumn{3}{|c|}{$\begin{array}{c}\text { Total Holdings over } \\
\text { Stock Market Capitalization }\end{array}$} & \multirow{2}{*}{$\begin{array}{c}\text { Average Mutual } \\
\text { Fund Size } \\
\text { (US\$ Million) }\end{array}$} \\
\hline & Average & Median & Std. Dev. & \\
\hline & & & & \\
\hline Global Funds & $0.12 \%$ & $0.01 \%$ & $0.75 \%$ & 899 \\
\hline World Funds & $0.18 \%$ & $0.01 \%$ & $0.86 \%$ & 1,320 \\
\hline Foreign Funds & $0.11 \%$ & $0.01 \%$ & $0.72 \%$ & 758 \\
\hline Specialized Funds & $0.12 \%$ & $0.02 \%$ & $0.59 \%$ & 277 \\
\hline Emerging Market Funds & $0.15 \%$ & $0.02 \%$ & $0.70 \%$ & 369 \\
\hline Asia Funds & $0.12 \%$ & $0.01 \%$ & $0.53 \%$ & 132 \\
\hline Europe Funds & $0.08 \%$ & $0.01 \%$ & $0.35 \%$ & 346 \\
\hline Latin America Funds & $0.10 \%$ & $0.02 \%$ & $0.47 \%$ & 144 \\
\hline
\end{tabular}

This table shows the average, median, and standard deviation of the total amount of mutual fund foreign holdings as a percentage of stock market capitalization over the 1997-2005 period by fund type. The average size of mutual funds, in millions of U.S. dollars, is also reported. The data on stock market capitalization at the firm level come from Worldscope. 
Table 6. Probabilities of Being Held by a Mutual Fund

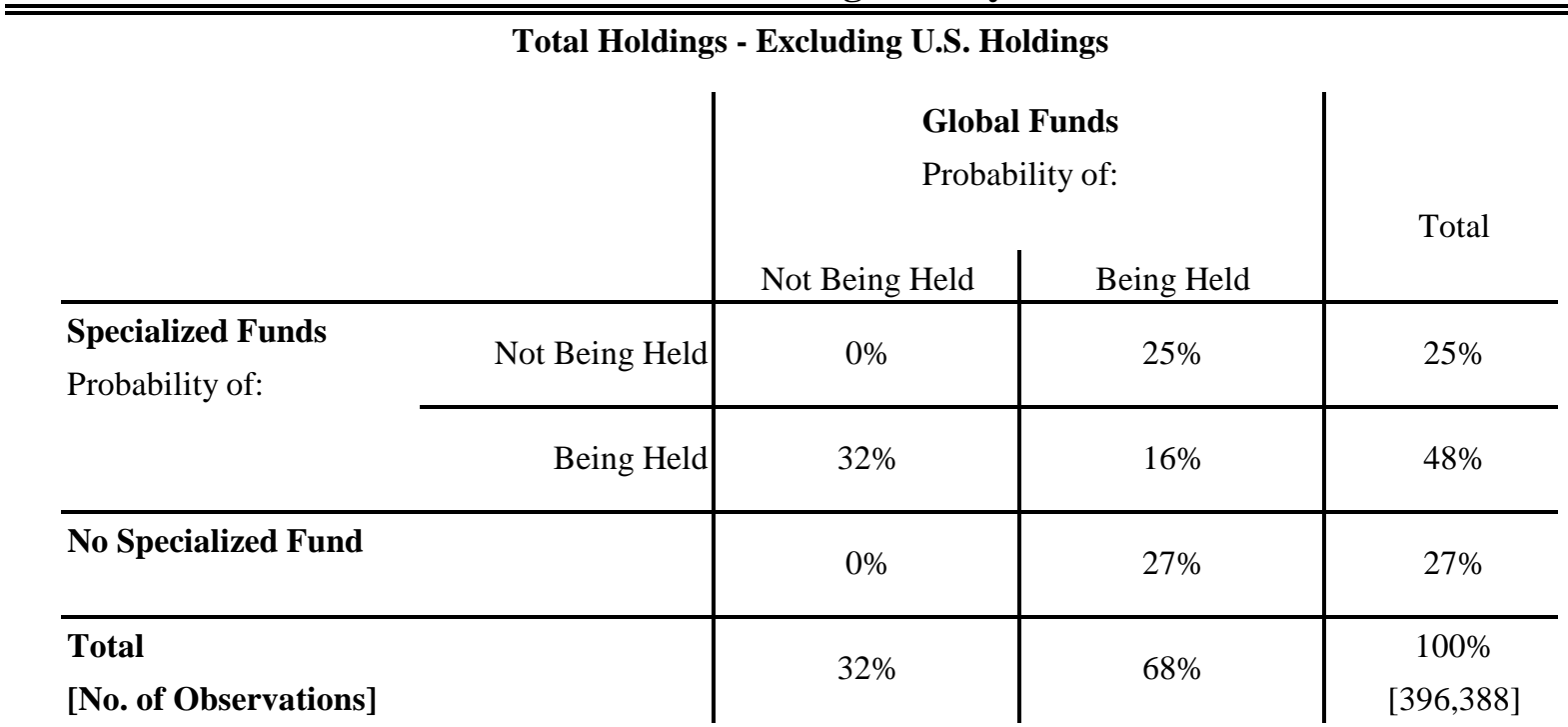

Holdings in Developing Countries Only

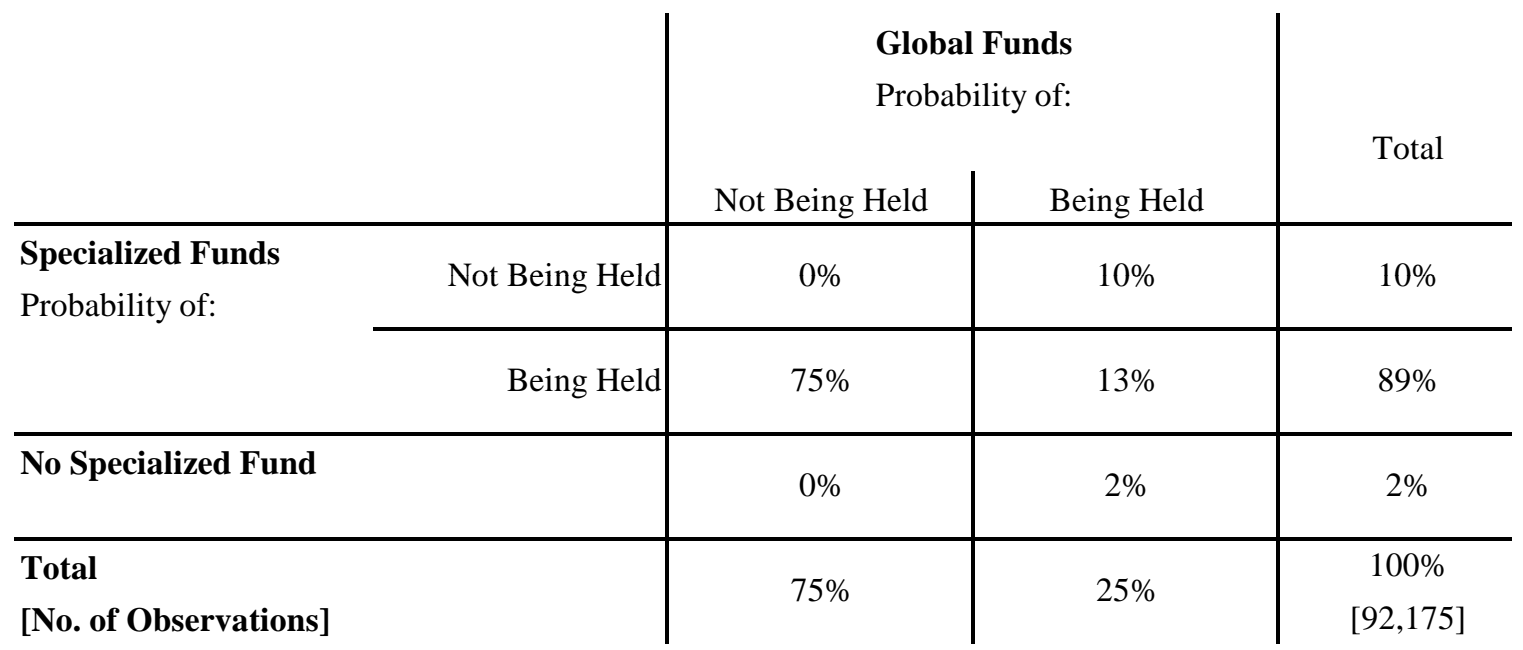

This table shows frequency counts for mutual fund stock holdings from 1997 to 2005. The reported numbers correspond to the probability of being held (or not) by certain types of mutual funds, given that a mutual fund family has both fund types. The top panel includes stock holdings in all countries except the U.S., whereas the bottom panel includes stock holdings in developing countries only. Each observation is a family-year-stock observation. The total number of observations is reported in brackets in the "Total" row of each table. When a global fund in a given familyyear holds a stock in a country not covered by the specialized funds within that family in that year, this observation is counted in the "No Specialized Fund" row. Global funds include both world funds and foreign funds. Specialized funds include: emerging market funds, regional funds, and country funds. 
Table 7. Commonality in Holdings across Fund Types

\begin{tabular}{|c|c|c|c|c|c|c|c|c|}
\hline & \multicolumn{8}{|c|}{ Dependent Variable: Entropy Measure } \\
\hline & \multicolumn{4}{|c|}{ All Holdings } & \multicolumn{4}{|c|}{ Holdings in Developing Countries Only } \\
\hline & (1) & $(2)$ & (3) & (4) & (5) & (6) & (7) & (8) \\
\hline \multicolumn{9}{|l|}{ Independent Variables } \\
\hline Number of Common Managers & $\begin{array}{l}0.061 * * * \\
{[0.006]}\end{array}$ & $\begin{array}{l}0.059 \text { *** } \\
{[0.006]}\end{array}$ & & & $\begin{array}{l}0.0544^{* * *} \\
{[0.008]}\end{array}$ & $\begin{array}{l}0.053 * * * \\
{[0.008]}\end{array}$ & & \\
\hline No Common Manager (NCM0) & & & $\begin{array}{l}0.292 \text { *** } \\
{[0.018]}\end{array}$ & $\begin{array}{l}0.207 \text { *** } \\
{[0.042]}\end{array}$ & & & $\begin{array}{l}0.363 \text { *** } \\
{[0.019]}\end{array}$ & $\begin{array}{l}0.409 * * * \\
{[0.043]}\end{array}$ \\
\hline One Common Manager (NCM1) & & & $\begin{array}{l}0.362 \text { *** } \\
{[0.034]}\end{array}$ & $\begin{array}{l}0.284 \text { *** } \\
{[0.052]}\end{array}$ & & & $\begin{array}{l}0.353 \text { *** } \\
{[0.033]}\end{array}$ & $\begin{array}{l}0.396 \text { *** } \\
{[0.051]}\end{array}$ \\
\hline Two Common Managers (NCM2) & & & $\begin{array}{l}0.421 * * * \\
{[0.031]}\end{array}$ & $\begin{array}{l}0.329 * * * \\
{[0.049]}\end{array}$ & & & $\begin{array}{l}0.553 * * * \\
{[0.037]}\end{array}$ & $\begin{array}{l}0.583 * * * \\
{[0.054]}\end{array}$ \\
\hline At Least Three Common Managers (NCM3) & & & $\begin{array}{l}0.543 \\
{[0.035]}\end{array}$ & $\begin{array}{l}0.456 \text { *** } \\
{[0.052]}\end{array}$ & & & $\begin{array}{l}0.589 \text { *** } \\
{[0.032]}\end{array}$ & $\begin{array}{l}0.633 \\
{[0.053]}\end{array}$ \\
\hline Year Dummies & No & Yes & No & Yes & No & Yes & No & Yes \\
\hline No. of Observations & 370 & 370 & 370 & 370 & 319 & 319 & 319 & 319 \\
\hline R-squared & 0.15 & 0.18 & 0.69 & 0.70 & 0.12 & 0.16 & 0.76 & 0.77 \\
\hline \multicolumn{9}{|l|}{ T-tests: } \\
\hline $\mathrm{NCM} 0=\mathrm{NCM} 1$ & & & $3.390 *$ & $4.060 * *$ & & & 0.070 & 0.120 \\
\hline $\mathrm{NCM} 0=\mathrm{NCM} 2$ & & & $13.190 * * *$ & $11.050 * * *$ & & & $20.670 * * *$ & $17.830 * * *$ \\
\hline NCM0 = NCM3 & & & $40.800 * * *$ & $42.230 * * *$ & & & $36.840 * * *$ & $36.510 * * *$ \\
\hline
\end{tabular}

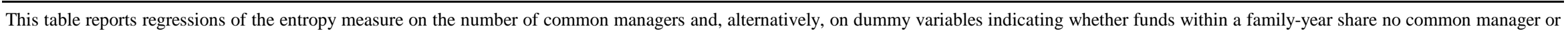
one, two, or three common managers. The entropy measure captures the commonality of stock holdings in the portfolios of global funds and specialized funds. The sample period is 1997-2005. T-tests of equality of the estimated coefficients on the dummy variables capturing the number of common managers are reported. Standard errors are clustered at the family level. Standard deviations are shown in brackets. ${ }^{* * *},{ }^{* *}$, and $*$ indicate significance at one, five, and ten percent, respectively. 
Table 8. Portfolio Choice of Mutual Funds: Importance of Year, Fund Type, and Family Effects

\begin{tabular}{|c|c|c|c|c|c|c|c|}
\hline & \multicolumn{7}{|c|}{ Dependent Variable: Number of Stock Holdings } \\
\hline & (1) & (2) & (3) & (4) & (5) & $(6)$ & $(7)$ \\
\hline R-squared & 0.01 & 0.02 & 0.46 & 0.03 & 0.46 & 0.47 & 0.48 \\
\hline \multicolumn{8}{|c|}{ Independent Variables } \\
\hline Year Dummies & Yes & No & No & Yes & Yes & No & Yes \\
\hline Fund Type Dummies & No & Yes & No & Yes & No & Yes & Yes \\
\hline Family Dummies & No & No & Yes & No & Yes & Yes & Yes \\
\hline \multirow[t]{3}{*}{ No. of Observations } & 6,394 & 6,394 & 6,394 & 6,394 & 6,394 & 6,394 & 6,394 \\
\hline & \multicolumn{7}{|c|}{ Dependent Variable: Percentage of Net Assets in Top Ten Holdings } \\
\hline & (1) & $(2)$ & (3) & $(4)$ & (5) & (6) & $(7)$ \\
\hline R-squared & 0.01 & 0.11 & 0.36 & 0.12 & 0.38 & 0.43 & 0.44 \\
\hline \multicolumn{8}{|c|}{ Independent Variables } \\
\hline Year Dummies & Yes & No & No & Yes & Yes & No & Yes \\
\hline Fund Type Dummies & No & Yes & No & Yes & No & Yes & Yes \\
\hline Family Dummies & No & No & Yes & No & Yes & Yes & Yes \\
\hline No. of Observations & 6,379 & 6,379 & 6,379 & 6,379 & 6,379 & 6,379 & 6,379 \\
\hline
\end{tabular}

In the top panel, the table reports regressions of the number of stock holdings on year dummies, fund type dummies, and/or family dummies. In the bottom panel, the table reports regressions of the percentage of net assets in the top ten stock holdings on year dummies, fund type dummies, and/or family dummies. The R-squared of these regressions is reported. The sample period is 1997-2005. Standard errors are clustered at the family level. 
Table 9. Portfolio Choice of Mutual Funds: Importance of Family Effects

\begin{tabular}{|c|c|c|c|c|c|c|c|c|c|c|}
\hline & \multicolumn{5}{|c|}{ Dependent Variable: Number of Stock Holdings } & \multicolumn{5}{|c|}{ Dependent Variable: Percentage of Net Assets in Top Ten Holdings } \\
\hline & (1) & (2) & (3) & (4) & (5) & (6) & (7) & (8) & (9) & (10) \\
\hline \multicolumn{11}{|l|}{ Independent Variables } \\
\hline Number of Managers & & $\begin{array}{l}16.180 \text { *** } \\
{[4.655]}\end{array}$ & $\begin{array}{l}14.762 * * * \\
{[4.569]}\end{array}$ & $\begin{array}{r}4.693 \\
{[3.702]}\end{array}$ & $\begin{array}{r}4.601 \\
{[3.703]}\end{array}$ & & $\begin{array}{l}-0.554 * * * \\
{[0.175]}\end{array}$ & $\begin{array}{l}-0.529 * * * \\
{[0.178]}\end{array}$ & $\begin{array}{r}-0.186 \\
{[0.188]}\end{array}$ & $\begin{array}{r}-0.179 \\
{[0.187]}\end{array}$ \\
\hline Dummy: 1 Manager & $\begin{array}{l}132.60 * * * \\
{[10.800]}\end{array}$ & & & & & $\begin{array}{l}29.07 \text { *** } \\
{[0.545]}\end{array}$ & & & & \\
\hline Dummy: 2 Managers & $\begin{array}{l}135.20 * * * \\
{[8.694]}\end{array}$ & & & & & $\begin{array}{l}27.58 * * * \\
{[0.664]}\end{array}$ & & & & \\
\hline Dummy: 3 Managers & $\begin{array}{l}153.60 * * * \\
{[19.300]}\end{array}$ & & & & & $\begin{array}{l}25.59 \text { *** } \\
{[1.012]}\end{array}$ & & & & \\
\hline Dummy: 4 Managers & $\begin{array}{l}166.20 * * * \\
{[20.100]}\end{array}$ & & & & & $\begin{array}{l}24.66 * * * \\
{[2.284]}\end{array}$ & & & & \\
\hline Dummy: 5 Managers & $\begin{array}{l}152.20 * * * \\
{[16.560]}\end{array}$ & & & & & $\begin{array}{l}24.30 * * * \\
{[1.100]}\end{array}$ & & & & \\
\hline Dummy: 6 Managers & $\begin{array}{l}196.90 * * * \\
{[31.310]}\end{array}$ & & & & & $\begin{array}{l}22.75 * * * \\
{[2.323]}\end{array}$ & & & & \\
\hline Dummy: 7 or More Managers & $\begin{array}{l}221.70 \text { *** } \\
{[28.130]}\end{array}$ & & & & & $\begin{array}{l}26.80 \text { *** } \\
{[0.971]}\end{array}$ & & & & \\
\hline Manager Tenure & & $\begin{array}{r}2.964 \\
{[2.488]}\end{array}$ & $\begin{array}{r}1.468 \\
{[2.255]}\end{array}$ & $\begin{array}{c}2.260 * \\
{[1.208]}\end{array}$ & $\begin{array}{c}2.243 * \\
{[1.203]}\end{array}$ & & $\begin{array}{r}-0.067 \\
{[0.118]}\end{array}$ & $\begin{array}{r}-0.033 \\
{[0.115]}\end{array}$ & $\begin{array}{r}-0.133 \\
{[0.084]}\end{array}$ & $\begin{array}{r}-0.129 \\
{[0.084]}\end{array}$ \\
\hline Fund Age & & $\begin{array}{r}0.211 \\
{[0.775]}\end{array}$ & $\begin{array}{r}0.316 \\
{[0.845]}\end{array}$ & $\begin{array}{c}-1.027 \\
{[0.863]}\end{array}$ & $\begin{array}{r}-1.013 \\
{[0.863]}\end{array}$ & & $\begin{array}{l}-0.129 * * \\
{[0.053]}\end{array}$ & $\begin{array}{l}-0.106 * * \\
{[0.052]}\end{array}$ & $\begin{array}{l}-0.126 * * \\
{[0.049]}\end{array}$ & $\begin{array}{l}-0.128 * * * \\
{[0.049]}\end{array}$ \\
\hline Family Expenses & & & $\begin{array}{l}-0.650 * * \\
{[0.252]}\end{array}$ & & $\begin{array}{r}-0.014 \\
{[0.160]}\end{array}$ & & & $\begin{array}{r}-0.001 \\
{[0.011]}\end{array}$ & & $\begin{array}{r}-0.010 \\
{[0.009]}\end{array}$ \\
\hline Family Size & & & $\begin{array}{l}7.535 \text { *** } \\
{[2.786]}\end{array}$ & & $\begin{array}{r}0.575 \\
{[1.543]}\end{array}$ & & & $\begin{array}{c}-0.062 \\
{[0.110]}\end{array}$ & & $\begin{array}{r}0.053 \\
{[0.088]}\end{array}$ \\
\hline Year Dummies & No & Yes & Yes & Yes & Yes & No & Yes & Yes & Yes & Yes \\
\hline Fund Type Dummies & No & Yes & Yes & Yes & Yes & No & Yes & Yes & Yes & Yes \\
\hline Family Dummies & No & No & No & Yes & Yes & No & No & No & Yes & Yes \\
\hline No. of Observations & 6,321 & 6,093 & 6,093 & 6,093 & 6,093 & 6,308 & 6,080 & 6,080 & 6,080 & 6,080 \\
\hline R-squared & 0.02 & 0.05 & 0.07 & 0.49 & 0.49 & 0.02 & 0.13 & 0.13 & 0.45 & 0.45 \\
\hline
\end{tabular}

This table reports regressions of the number of stock holdings and the percentage of net assets in the top ten stock holdings on the number of managers, manager tenure, fund age, mutual fund family expenses, and mutual fund family size. Depending on the specification, year, fund type, and/or family dummies are included. Family expenses are in millions of U.S. dollars and family size is in billions of U.S. dollars. Fund age is expressed in years. The sample period is 1997-2005. Standard errors are clustered at the family level. Standard deviations are shown in brackets. ***, **, and * indicate significance at one, five, and ten percent, respectively. 
Table 10. Simulations Using the Largest Number of Funds

\begin{tabular}{|c|c|c|c|c|c|c|}
\hline \multirow[b]{3}{*}{ Type of Global Funds } & \multicolumn{6}{|c|}{ Minimizing the Variance } \\
\hline & \multicolumn{2}{|c|}{$\begin{array}{l}\text { Average Returns } \\
\text { (Per Year) }\end{array}$} & \multirow{2}{*}{$\begin{array}{c}\text { Average } \\
\text { Difference in } \\
\text { Accumulated } \\
\text { Returns } \\
\end{array}$} & \multicolumn{2}{|c|}{$\begin{array}{c}\text { Standard Deviation of } \\
\text { Returns }\end{array}$} & \multirow[b]{2}{*}{$\begin{array}{c}\text { Number of } \\
\text { Comparisons }\end{array}$} \\
\hline & $\begin{array}{l}\text { Global } \\
\text { Funds }\end{array}$ & $\begin{array}{c}\text { Simulated } \\
\text { Global Funds }\end{array}$ & & $\begin{array}{l}\text { Global } \\
\text { Funds }\end{array}$ & $\begin{array}{c}\text { Simulated } \\
\text { Global Funds }\end{array}$ & \\
\hline \multicolumn{7}{|l|}{ Daily Data } \\
\hline World Funds & $6.22 \%$ & $11.01 \%$ & $4.85 \%$ & $0.87 \%$ & $0.78 \%$ & 63 \\
\hline Foreign Funds & $6.03 \%$ & $9.95 \%$ & $4.03 \%$ & $0.97 \%$ & $0.89 \%$ & 77 \\
\hline Pools of World or Foreign Funds & $10.53 \%$ & $15.23 \%$ & $4.55 \%$ & $0.86 \%$ & $0.80 \%$ & 25 \\
\hline Total & $6.78 \%$ & $11.14 \%$ & $4.42 \%$ & $0.92 \%$ & $0.84 \%$ & 165 \\
\hline \multicolumn{7}{|l|}{ Weekly Data } \\
\hline World Funds & $6.28 \%$ & $11.33 \%$ & $5.08 \%$ & $2.05 \%$ & $1.92 \%$ & 63 \\
\hline Foreign Funds & $6.04 \%$ & $9.70 \%$ & $3.74 \%$ & $2.25 \%$ & $2.13 \%$ & 77 \\
\hline Pools of World or Foreign Funds & $10.54 \%$ & $15.16 \%$ & $4.44 \%$ & $1.99 \%$ & $1.90 \%$ & 25 \\
\hline Total & $6.80 \%$ & $11.13 \%$ & $4.36 \%$ & $2.14 \%$ & $2.01 \%$ & 165 \\
\hline & \multicolumn{6}{|c|}{ Maximizing Expected Returns } \\
\hline & \multicolumn{2}{|c|}{$\begin{array}{c}\text { Average Returns } \\
\text { (Per Year) }\end{array}$} & \multirow{2}{*}{$\begin{array}{c}\text { Average } \\
\text { Difference in } \\
\text { Accumulated } \\
\text { Returns } \\
\end{array}$} & \multicolumn{2}{|c|}{$\begin{array}{c}\text { Standard Deviation of } \\
\text { Returns }\end{array}$} & \\
\hline Type of Global Funds & $\begin{array}{l}\text { Global } \\
\text { Funds }\end{array}$ & $\begin{array}{c}\text { Simulated } \\
\text { Global Funds }\end{array}$ & & $\begin{array}{l}\text { Global } \\
\text { Funds }\end{array}$ & $\begin{array}{c}\text { Simulated } \\
\text { Global Funds }\end{array}$ & $\begin{array}{c}\text { Number of } \\
\text { Comparisons }\end{array}$ \\
\hline \multicolumn{7}{|l|}{ Daily Data } \\
\hline World Funds & $6.22 \%$ & $10.68 \%$ & $4.46 \%$ & $0.87 \%$ & $0.83 \%$ & 63 \\
\hline Foreign Funds & $6.03 \%$ & $10.49 \%$ & $4.49 \%$ & $0.97 \%$ & $0.92 \%$ & 77 \\
\hline Pools of World or Foreign Funds & $10.53 \%$ & $14.21 \%$ & $3.59 \%$ & $0.86 \%$ & $0.83 \%$ & 25 \\
\hline Total & $6.78 \%$ & $11.12 \%$ & $4.34 \%$ & $0.92 \%$ & $0.87 \%$ & 165 \\
\hline \multicolumn{7}{|l|}{ Weekly Data } \\
\hline World Funds & $6.28 \%$ & $12.48 \%$ & $6.09 \%$ & $2.05 \%$ & $2.13 \%$ & 63 \\
\hline Foreign Funds & $6.04 \%$ & $11.14 \%$ & $4.98 \%$ & $2.25 \%$ & $2.30 \%$ & 77 \\
\hline Pools of World or Foreign Funds & $10.54 \%$ & $16.67 \%$ & $5.74 \%$ & $1.99 \%$ & $2.10 \%$ & 25 \\
\hline Total & $6.80 \%$ & $12.47 \%$ & $5.52 \%$ & $2.14 \%$ & $2.20 \%$ & 165 \\
\hline \multicolumn{7}{|c|}{$\begin{array}{l}\text { This table shows differences in the average and standard deviation of returns between global funds and simulated global funds. Simulated globa } \\
\text { funds are constructed from actual global funds and specialized funds in the same mutual fund family using two different procedures. The top pane } \\
\text { shows the results of minimizing the variance of returns subject to a restriction on expected returns. The bottom panel shows the results o } \\
\text { maximizing expected returns subject to a restriction on the variance of returns. The simulations use portfolios that include the largest number o } \\
\text { available specialized funds for each global fund in each family. Global funds are world funds, foreign funds, and a pool of world or foreign funds } \\
\text { The pools of world or foreign funds are simulations that include several world (or foreign) funds within the same family but with different scopes } \\
\text { e.g. world (foreign) value funds and world (foreign) growth funds. Portfolio weights are updated daily or weekly depending on the data frequency } \\
\text { considered. Realized returns of the simulated portfolios are calculated out-of-sample, as described in the main text. Annualized differences in } \\
\text { accumulated returns are calculated over the entire sample for each simulation performed. Averages across simulations are then computed anc } \\
\text { reported. }\end{array}$} \\
\hline
\end{tabular}


Table 11. Simulations Using the Longest Available Sample

\begin{tabular}{|c|c|c|c|c|c|c|}
\hline \multirow[b]{3}{*}{ Type of Global Funds } & \multicolumn{6}{|c|}{ Minimizing the Variance } \\
\hline & \multicolumn{2}{|c|}{$\begin{array}{c}\text { Average Returns } \\
\text { (Per Year) }\end{array}$} & \multirow{2}{*}{$\begin{array}{c}\text { Average } \\
\text { Difference in } \\
\text { Accumulated } \\
\text { Returns } \\
\end{array}$} & \multicolumn{2}{|c|}{$\begin{array}{c}\text { Standard Deviation of } \\
\text { Returns }\end{array}$} & \multirow[b]{2}{*}{$\begin{array}{c}\text { Number of } \\
\text { Comparisons }\end{array}$} \\
\hline & $\begin{array}{l}\text { Global } \\
\text { Funds }\end{array}$ & $\begin{array}{c}\text { Simulated Global } \\
\text { Funds } \\
\end{array}$ & & $\begin{array}{l}\text { Global } \\
\text { Funds }\end{array}$ & $\begin{array}{c}\text { Simulated } \\
\text { Global Funds } \\
\end{array}$ & \\
\hline \multicolumn{7}{|l|}{ Daily Data } \\
\hline World Funds & $6.81 \%$ & $9.50 \%$ & $2.79 \%$ & $0.91 \%$ & $0.84 \%$ & 63 \\
\hline Foreign Funds & $5.09 \%$ & $7.69 \%$ & $2.75 \%$ & $0.97 \%$ & $0.90 \%$ & 77 \\
\hline Pools of World or Foreign Funds & $7.67 \%$ & $11.62 \%$ & $4.00 \%$ & $0.92 \%$ & $0.85 \%$ & 25 \\
\hline Total & $6.13 \%$ & $8.97 \%$ & $2.95 \%$ & $0.94 \%$ & $0.87 \%$ & 165 \\
\hline \multicolumn{7}{|l|}{ Weekly Data } \\
\hline World Funds & $8.07 \%$ & $9.78 \%$ & $2.44 \%$ & $2.66 \%$ & $2.16 \%$ & 63 \\
\hline Foreign Funds & $5.11 \%$ & $7.33 \%$ & $2.33 \%$ & $2.25 \%$ & $2.16 \%$ & 77 \\
\hline Pools of World or Foreign Funds & $7.87 \%$ & $11.93 \%$ & $4.08 \%$ & $2.17 \%$ & $2.03 \%$ & 25 \\
\hline \multirow[t]{3}{*}{ Total } & $6.65 \%$ & $8.95 \%$ & $2.64 \%$ & $2.40 \%$ & $2.14 \%$ & 165 \\
\hline & \multicolumn{6}{|c|}{ Maximizing Expected Returns } \\
\hline & \multicolumn{2}{|c|}{$\begin{array}{c}\text { Average Returns } \\
\text { (Per Year) }\end{array}$} & \multirow{2}{*}{$\begin{array}{c}\text { Average } \\
\text { Difference in } \\
\text { Accumulated } \\
\text { Returns } \\
\end{array}$} & \multicolumn{2}{|c|}{$\begin{array}{c}\text { Standard Deviation of } \\
\text { Returns }\end{array}$} & \\
\hline Type of Global Funds & $\begin{array}{l}\text { Global } \\
\text { Funds }\end{array}$ & $\begin{array}{c}\text { Simulated Global } \\
\text { Funds } \\
\end{array}$ & & $\begin{array}{c}\text { Global } \\
\text { Fund }\end{array}$ & $\begin{array}{c}\text { Simulated } \\
\text { Global Funds } \\
\end{array}$ & $\begin{array}{c}\begin{array}{c}\text { Number of } \\
\text { Comparisons }\end{array} \\
\end{array}$ \\
\hline \multicolumn{7}{|l|}{ Daily Data } \\
\hline World Funds & $6.81 \%$ & $9.60 \%$ & $2.86 \%$ & $0.91 \%$ & $0.85 \%$ & 63 \\
\hline Foreign Funds & $5.09 \%$ & $7.98 \%$ & $2.98 \%$ & $0.97 \%$ & $0.92 \%$ & 77 \\
\hline Pools of World or Foreign Funds & $7.67 \%$ & $11.22 \%$ & $3.59 \%$ & $0.92 \%$ & $0.88 \%$ & 25 \\
\hline Total & $6.13 \%$ & $9.08 \%$ & $3.02 \%$ & $0.94 \%$ & $0.88 \%$ & 165 \\
\hline \multicolumn{7}{|l|}{ Weekly Data } \\
\hline World Funds & $8.07 \%$ & $10.87 \%$ & $3.20 \%$ & $2.66 \%$ & $2.37 \%$ & 63 \\
\hline Foreign Funds & $5.11 \%$ & $8.35 \%$ & $3.20 \%$ & $2.25 \%$ & $2.26 \%$ & 77 \\
\hline Pools of World or Foreign Funds & $7.87 \%$ & $13.55 \%$ & $5.51 \%$ & $2.17 \%$ & $2.22 \%$ & 25 \\
\hline Total & $6.65 \%$ & $10.08 \%$ & $3.55 \%$ & $2.40 \%$ & $2.30 \%$ & 165 \\
\hline
\end{tabular}

$\overline{\text { This table shows differences in the average and standard deviation of returns between global funds and simulated global funds. Simulated global funds }}$ are constructed from actual global funds and specialized funds in the same mutual fund family using two different procedures. The top panel shows the results of minimizing the variance of returns subject to a restriction on expected returns. The bottom panel shows the results of maximizing expected returns subject to a restriction on the variance of returns. The simulations use portfolios that include the longest time series for each global fund in each family. Global funds are world funds, foreign funds, and a pool of world or foreign funds. The pools of world or foreign funds are simulations that include several world (or foreign) funds within the same family but with different scopes, e.g. world (foreign) value funds and world (foreign) growth funds. Portfolio weights are updated daily or weekly depending on the data frequency considered. Realized returns of the simulated portfolios are calculated out-of-sample, as described in the main text. Annualized differences in accumulated returns are calculated over the entire sample for each simulation performed. Averages across simulations are then computed and reported. 
Table 12. Benchmarking: Simulations Using the Largest Number of Funds

\begin{tabular}{|c|c|c|c|c|c|c|}
\hline \multirow[b]{3}{*}{ Type of Global Funds } & \multicolumn{6}{|c|}{ Minimizing the Variance } \\
\hline & \multicolumn{2}{|c|}{$\begin{array}{l}\text { Average Returns } \\
\text { (Per Year) }\end{array}$} & \multirow{2}{*}{$\begin{array}{c}\text { Average } \\
\text { Difference in } \\
\text { Accumulated } \\
\text { Daily Returns }\end{array}$} & \multicolumn{2}{|c|}{$\begin{array}{c}\text { Standard Deviation of Daily } \\
\text { Returns }\end{array}$} & \multirow[b]{2}{*}{$\begin{array}{c}\text { Number of } \\
\text { Comparisons }\end{array}$} \\
\hline & $\begin{array}{l}\text { Global } \\
\text { Funds }\end{array}$ & $\begin{array}{c}\text { Simulated } \\
\text { Global Funds }\end{array}$ & & $\begin{array}{l}\text { Global } \\
\text { Funds }\end{array}$ & $\begin{array}{c}\text { Simulated } \\
\text { Global Funds }\end{array}$ & \\
\hline World Funds & $8.71 \%$ & $12.10 \%$ & $3.43 \%$ & $0.88 \%$ & $0.82 \%$ & 56 \\
\hline Foreign Funds & $5.99 \%$ & $9.68 \%$ & $3.79 \%$ & $0.97 \%$ & $0.91 \%$ & 77 \\
\hline Pools of World or Foreign Funds & $10.60 \%$ & $14.88 \%$ & $4.20 \%$ & $0.86 \%$ & $0.85 \%$ & 24 \\
\hline \multirow[t]{3}{*}{ Total } & $7.65 \%$ & $11.32 \%$ & $3.72 \%$ & $0.92 \%$ & $0.87 \%$ & 157 \\
\hline & \multicolumn{6}{|c|}{ Maximizing Expected Returns } \\
\hline & \multicolumn{2}{|c|}{$\begin{array}{c}\text { Average Returns } \\
\text { (Per Year) } \\
\end{array}$} & \multirow{2}{*}{$\begin{array}{c}\text { Average } \\
\text { Difference in } \\
\text { Accumulated } \\
\text { Daily Returns } \\
\end{array}$} & \multicolumn{2}{|c|}{$\begin{array}{c}\text { Standard Deviation of Daily } \\
\text { Returns } \\
\end{array}$} & \\
\hline Type of Global Funds & $\begin{array}{l}\text { Global } \\
\text { Funds }\end{array}$ & $\begin{array}{c}\text { Simulated } \\
\text { Global Funds } \\
\end{array}$ & & $\begin{array}{l}\text { Global } \\
\text { Funds }\end{array}$ & $\begin{array}{c}\text { Simulated } \\
\text { Global Funds }\end{array}$ & $\begin{array}{c}\text { Number of } \\
\text { Comparisons }\end{array}$ \\
\hline World Funds & $8.71 \%$ & $11.96 \%$ & $3.36 \%$ & $0.88 \%$ & $0.78 \%$ & 56 \\
\hline Foreign Funds & $5.99 \%$ & $10.41 \%$ & $4.51 \%$ & $0.97 \%$ & $0.90 \%$ & 77 \\
\hline Pools of World or Foreign Funds & $10.60 \%$ & $14.69 \%$ & $4.00 \%$ & $0.86 \%$ & $0.83 \%$ & 24 \\
\hline Total & $7.65 \%$ & $11.61 \%$ & $4.02 \%$ & $0.92 \%$ & $0.85 \%$ & 157 \\
\hline
\end{tabular}

This table shows differences in the average and standard deviation of returns between global funds and simulated global funds. Simulated global funds are constructed from actual global funds and specialized funds in the same mutual fund family using two different procedures. The top panel shows the results of minimizing the variance of returns relative to a benchmark index subject to a restriction on expected returns. The bottom panel shows the results of maximizing expected returns subject to a restriction on the variance of returns relative to a benchmark index. The simulations use portfolios that include the largest number of available specialized funds for each global fund in each family. An appropriate benchmark index is used for each simulation. Global funds are world funds, foreign funds, and a pool of world or foreign funds. The pools of world or foreign funds are simulations that include several world (or foreign) funds within the same family but with different scopes, e.g. world (foreign) value funds and world (foreign) growth funds. Portfolio weights are updated daily. Realized returns of the simulated portfolios are calculated out-of-sample, as described in the main text. Annualized differences in accumulated returns are calculated over the entire sample for each simulation performed. Averages across simulations are then computed and reported. 
Table 13. Benchmarking: Simulations Using the Longest Available Sample

\begin{tabular}{|c|c|c|c|c|c|c|}
\hline \multirow[b]{3}{*}{ Type of Global Funds } & \multicolumn{6}{|c|}{ Minimizing the Variance } \\
\hline & \multicolumn{2}{|c|}{$\begin{array}{c}\text { Average Returns } \\
\text { (Per Year) }\end{array}$} & \multirow{2}{*}{$\begin{array}{c}\text { Average } \\
\text { Difference in } \\
\text { Accumulated } \\
\text { Daily Returns } \\
\end{array}$} & \multicolumn{2}{|c|}{$\begin{array}{l}\text { Standard Deviation of Daily } \\
\text { Returns }\end{array}$} & \multirow[b]{2}{*}{$\begin{array}{c}\text { Number of } \\
\text { Comparisons } \\
\end{array}$} \\
\hline & $\begin{array}{l}\text { Global } \\
\text { Funds } \\
\end{array}$ & $\begin{array}{c}\text { Simulated } \\
\text { Global Funds }\end{array}$ & & $\begin{array}{l}\text { Global } \\
\text { Funds } \\
\end{array}$ & $\begin{array}{c}\text { Simulated } \\
\text { Global Funds }\end{array}$ & \\
\hline World Funds & $7.83 \%$ & $10.28 \%$ & $2.56 \%$ & $0.91 \%$ & $0.85 \%$ & 63 \\
\hline Foreign Funds & $5.06 \%$ & $7.53 \%$ & $2.58 \%$ & $0.97 \%$ & $0.91 \%$ & 77 \\
\hline Pools of World or Foreign Funds & $7.49 \%$ & $11.66 \%$ & $4.24 \%$ & $0.93 \%$ & $0.89 \%$ & 24 \\
\hline \multirow[t]{3}{*}{ Total } & $6.47 \%$ & $9.18 \%$ & $2.82 \%$ & $0.94 \%$ & $0.89 \%$ & 164 \\
\hline & \multicolumn{6}{|c|}{ Maximizing Expected Returns } \\
\hline & \multicolumn{2}{|c|}{$\begin{array}{c}\text { Average Returns } \\
\text { (Per Year) }\end{array}$} & \multirow{2}{*}{$\begin{array}{c}\text { Average } \\
\text { Difference in } \\
\text { Accumulated } \\
\text { Daily Returns } \\
\end{array}$} & \multicolumn{2}{|c|}{$\begin{array}{l}\text { Standard Deviation of Daily } \\
\text { Returns } \\
\end{array}$} & \\
\hline Type of Global Funds & $\begin{array}{l}\text { Global } \\
\text { Funds }\end{array}$ & $\begin{array}{c}\text { Simulated } \\
\text { Global Funds }\end{array}$ & & $\begin{array}{l}\text { Global } \\
\text { Funds } \\
\end{array}$ & $\begin{array}{c}\text { Simulated } \\
\text { Global Funds }\end{array}$ & $\begin{array}{c}\text { Number of } \\
\text { Comparisons } \\
\end{array}$ \\
\hline World Funds & $7.83 \%$ & $10.13 \%$ & $2.48 \%$ & $0.91 \%$ & $0.82 \%$ & 63 \\
\hline Foreign Funds & $5.06 \%$ & $8.19 \%$ & $3.28 \%$ & $0.97 \%$ & $0.90 \%$ & 77 \\
\hline Pools of World or Foreign Funds & $7.49 \%$ & $12.44 \%$ & $4.94 \%$ & $0.93 \%$ & $0.87 \%$ & 24 \\
\hline Total & $6.47 \%$ & $9.55 \%$ & $3.22 \%$ & $0.94 \%$ & $0.86 \%$ & 164 \\
\hline
\end{tabular}

This table shows differences in the average and standard deviation of returns between global funds and simulated global funds. Simulated global funds are constructed from actual global funds and specialized funds in the same mutual fund family using two different procedures. The top panel shows the results of minimizing the variance of returns relative to a benchmark index subject to a restriction on expected returns. The bottom panel shows the results of maximizing expected returns subject to a restriction on the variance of returns relative to a benchmark index. The simulations use portfolios that include the longest time series for each global fund in each family. An appropriate benchmark index is used for each simulation. Global funds are world funds, foreign funds, and a pool of world or foreign funds. The pools of world or foreign funds are simulations that include several world (or foreign) funds within the same family but with different scopes, e.g. world (foreign) value funds and world (foreign) growth funds. Portfolio weights are updated daily. Realized returns of the simulated portfolios are calculated out-of-sample, as described in the main text. Annualized differences in accumulated returns are calculated over the entire sample for each simulation performed. Averages across simulations are then computed and reported. 
Table 14. Skewness and Kurtosis Based on Simulations Using the Largest Number of Funds

\begin{tabular}{|c|c|c|c|c|c|}
\hline & \multicolumn{5}{|c|}{ Minimizing the Variance } \\
\hline & \multicolumn{2}{|c|}{ Daily Returns on Global Funds } & \multicolumn{2}{|c|}{$\begin{array}{c}\text { Daily Returns on Simulated } \\
\text { Global Funds }\end{array}$} & \multirow{2}{*}{$\begin{array}{c}\text { Number of } \\
\text { Comparisons }\end{array}$} \\
\hline & Skewness & Kurtosis & Skewness & Kurtosis & \\
\hline \multicolumn{6}{|l|}{ Type of Global Funds } \\
\hline World Funds & $\begin{array}{l}-0.63 \\
{[0.99]}\end{array}$ & $\begin{array}{c}10.15 \\
{[14.56]}\end{array}$ & $\begin{array}{l}-0.70 \\
{[0.93]}\end{array}$ & $\begin{array}{c}8.78 \\
{[16.21]}\end{array}$ & 63 \\
\hline Foreign Funds & $\begin{array}{c}-0.83 \\
{[1.21]}\end{array}$ & $\begin{array}{c}12.47 \\
{[19.55]}\end{array}$ & $\begin{array}{c}-0.97 \\
{[0.87]}\end{array}$ & $\begin{array}{c}11.13 \\
{[11.13]}\end{array}$ & 77 \\
\hline Pools of World or Foreign Funds & $\begin{array}{c}-0.42 \\
{[0.49]}\end{array}$ & $\begin{array}{c}6.57 \\
{[5.64]}\end{array}$ & $\begin{array}{c}-0.79 \\
{[0.90]}\end{array}$ & $\begin{array}{c}9.85 \\
{[11.91]}\end{array}$ & 25 \\
\hline \multirow[t]{4}{*}{ Total } & $\begin{array}{c}-0.69 \\
{[1.05]}\end{array}$ & $\begin{array}{c}10.69 \\
{[16.31]}\end{array}$ & $\begin{array}{l}-0.84 \\
{[0.90]}\end{array}$ & $\begin{array}{c}10.04 \\
{[13.37]}\end{array}$ & 165 \\
\hline & \multicolumn{5}{|c|}{ Maximizing Expected Returns } \\
\hline & \multicolumn{2}{|c|}{ Daily Returns on Global Funds } & \multicolumn{2}{|c|}{$\begin{array}{c}\text { Daily Returns on Simulated } \\
\text { Global Funds } \\
\end{array}$} & Number of \\
\hline & Skewness & Kurtosis & Skewness & Kurtosis & Comparisons \\
\hline \multicolumn{6}{|l|}{ Type of Global Funds } \\
\hline World Funds & $\begin{array}{c}-0.63 \\
{[0.99]}\end{array}$ & $\begin{array}{c}10.15 \\
{[14.56]}\end{array}$ & $\begin{array}{c}-0.57 \\
{[0.40]}\end{array}$ & $\begin{array}{c}6.12 \\
{[4.71]}\end{array}$ & 63 \\
\hline Foreign Funds & $\begin{array}{c}-0.83 \\
{[1.21]}\end{array}$ & $\begin{array}{c}12.47 \\
{[19.55]}\end{array}$ & $\begin{array}{c}-0.86 \\
{[0.65]}\end{array}$ & $\begin{array}{c}9.28 \\
{[6.55]}\end{array}$ & 77 \\
\hline Pools of World or Foreign Funds & $\begin{array}{c}-0.42 \\
{[0.49]}\end{array}$ & $\begin{array}{c}6.57 \\
{[5.64]}\end{array}$ & $\begin{array}{c}-0.57 \\
{[0.55]}\end{array}$ & $\begin{array}{c}7.03 \\
{[3.95]}\end{array}$ & 25 \\
\hline Total & $\begin{array}{c}-0.69 \\
{[1.05]}\end{array}$ & $\begin{array}{c}10.69 \\
{[16.31]}\end{array}$ & $\begin{array}{l}-0.70 \\
{[0.57]}\end{array}$ & $\begin{array}{c}7.74 \\
{[5.73]}\end{array}$ & 165 \\
\hline \multicolumn{6}{|c|}{$\begin{array}{l}\text { This table shows the average skewness and kurtosis of returns of global funds and simulated global funds. Simulated global funds are } \\
\text { constructed from actual global funds and specialized funds in the same mutual fund family using two different procedures. The top } \\
\text { panel shows the results of minimizing the variance of returns subject to a restriction on the expected return. The bottom panel shows } \\
\text { the results of maximizing expected returns subject to a restriction on the variance of returns. The simulations use portfolios that } \\
\text { include the largest number of available specialized funds for each global fund in each family. Global funds are world funds, foreign } \\
\text { funds, and a pool of world or foreign funds. The pools of world or foreign funds are simulations that include several world (or foreign) } \\
\text { funds within the same family but with different scopes, e.g. world (foreign) value funds and world (foreign) growth funds. Portfolio } \\
\text { weights are updated daily. Realized returns of the simulated portfolios are calculated out-of-sample, as described in the main text. } \\
\text { Standard deviations of both skewness and kurtosis are reported in brackets. }\end{array}$} \\
\hline
\end{tabular}


Table 15. Skewness and Kurtosis Based on Simulations Using the Longest Available Sample

\begin{tabular}{|c|c|c|c|c|c|}
\hline & \multicolumn{5}{|c|}{ Minimizing the Variance } \\
\hline & \multicolumn{2}{|c|}{ Daily Returns on Global Funds } & \multicolumn{2}{|c|}{$\begin{array}{c}\text { Daily Returns on Simulated } \\
\text { Global Funds }\end{array}$} & \multirow{2}{*}{$\begin{array}{c}\text { Number of } \\
\text { Comparisons }\end{array}$} \\
\hline & Skewness & Kurtosis & Skewness & Kurtosis & \\
\hline \multicolumn{6}{|l|}{ Type of Global Funds } \\
\hline World Funds & $\begin{array}{c}-0.82 \\
{[1.10]}\end{array}$ & $\begin{array}{c}13.70 \\
{[16.07]}\end{array}$ & $\begin{array}{c}-0.82 \\
{[0.84]}\end{array}$ & $\begin{array}{c}11.19 \\
{[12.48]}\end{array}$ & 63 \\
\hline Foreign Funds & $\begin{array}{c}-0.92 \\
{[1.23]}\end{array}$ & $\begin{array}{c}14.18 \\
{[20.34]}\end{array}$ & $\begin{array}{l}-1.06 \\
{[0.90]}\end{array}$ & $\begin{array}{c}13.21 \\
{[12.37]}\end{array}$ & 77 \\
\hline Pools of World or Foreign Funds & $\begin{array}{c}-0.44 \\
{[0.43]}\end{array}$ & $\begin{array}{c}6.61 \\
{[4.48]}\end{array}$ & $\begin{array}{c}-0.83 \\
{[0.88]}\end{array}$ & $\begin{array}{c}10.07 \\
{[11.86]}\end{array}$ & 25 \\
\hline Total & $\begin{array}{c}-0.81 \\
{[1.10]}\end{array}$ & $\begin{array}{c}12.85 \\
{[17.30]}\end{array}$ & $\begin{array}{c}-0.94 \\
{[0.88]}\end{array}$ & $\begin{array}{c}11.96 \\
{[12.33]}\end{array}$ & 165 \\
\hline & \multicolumn{5}{|c|}{ Maximizing Expected Returns } \\
\hline & \multicolumn{2}{|c|}{ Daily Returns on Global Funds } & \multicolumn{2}{|c|}{$\begin{array}{c}\text { Daily Returns on Simulated } \\
\text { Global Funds }\end{array}$} & Number of \\
\hline \multirow{2}{*}{\multicolumn{6}{|c|}{ Type of Global Funds }} \\
\hline & & & & & \\
\hline World Funds & $\begin{array}{l}-0.82 \\
{[1.10]}\end{array}$ & $\begin{array}{c}13.70 \\
{[16.07]}\end{array}$ & $\begin{array}{l}-0.63 \\
{[0.51]}\end{array}$ & $\begin{array}{c}7.98 \\
{[7.52]}\end{array}$ & 63 \\
\hline Foreign Funds & $\begin{array}{c}-0.92 \\
{[1.23]}\end{array}$ & $\begin{array}{c}14.18 \\
{[20.34]}\end{array}$ & $\begin{array}{c}-0.87 \\
{[0.61]}\end{array}$ & $\begin{array}{c}9.55 \\
{[6.09]}\end{array}$ & 77 \\
\hline Pools of World or Foreign Funds & $\begin{array}{c}-0.44 \\
{[0.43]}\end{array}$ & $\begin{array}{c}6.61 \\
{[4.48]}\end{array}$ & $\begin{array}{c}-0.60 \\
{[0.50]}\end{array}$ & $\begin{array}{c}7.22 \\
{[3.69]}\end{array}$ & 25 \\
\hline Total & $\begin{array}{c}-0.81 \\
{[1.10]}\end{array}$ & $\begin{array}{c}12.85 \\
{[17.30]}\end{array}$ & $\begin{array}{c}-0.74 \\
{[0.57]}\end{array}$ & $\begin{array}{c}8.60 \\
{[6.44]}\end{array}$ & 165 \\
\hline
\end{tabular}

This table shows the average skewness and kurtosis of returns of global funds and simulated global funds. Simulated global funds are constructed from actual global funds and specialized funds in the same mutual fund family using two different procedures. The top panel shows the results of minimizing the variance of returns subject to a restriction on the expected return. The bottom panel shows the results of maximizing expected returns subject to a restriction on the variance of returns. The simulations use portfolios that include the longest time series for each global fund in each family. Global funds are world funds, foreign funds, and a pool of world or foreign funds. The pools of world or foreign funds are simulations that include several world (or foreign) funds within the same family but with different scopes, e.g. world (foreign) value funds and world (foreign) growth funds. Portfolio weights are updated daily. Realized returns of the simulated portfolios are calculated out-of-sample, as described in the main text. Standard deviations of both skewness and kurtosis are reported in brackets. 
Table 16. Average Returns Conditional on MSCI Emerging Market Index Returns

\begin{tabular}{|c|c|c|c|c|}
\hline & \multicolumn{2}{|c|}{ Average Returns (Per Week) } & \multirow[b]{2}{*}{$\begin{array}{c}\text { T-test: } \\
(\mathrm{P})=(\mathrm{G})\end{array}$} & \multirow[b]{2}{*}{$\begin{array}{c}\text { Number of } \\
\text { Observations }\end{array}$} \\
\hline & $\begin{array}{c}\text { Global Funds } \\
\text { (G) } \\
\end{array}$ & $\begin{array}{c}\text { Simulated } \\
\text { Global Funds } \\
\text { (P) }\end{array}$ & & \\
\hline \multicolumn{5}{|l|}{ Minimizing the Variance } \\
\hline \multicolumn{5}{|l|}{ Largest Number of Funds Simulations } \\
\hline MSCI Returns between $0 \%$ and $-1 \%$ & $-0.37 \%$ & $-0.27 \%$ & $3.27 * * *$ & 4,878 \\
\hline MSCI Returns between $-1 \%$ and $-5 \%$ & $-1.53 \%$ & $-1.49 \%$ & $1.71 *$ & 10,193 \\
\hline MSCI Returns between -5\% and -10\% & $-4.00 \%$ & $-4.35 \%$ & $-2.24 * *$ & 950 \\
\hline MSCI Returns less than $-10 \%$ & $-3.42 \%$ & $-3.45 \%$ & -0.12 & 191 \\
\hline \multicolumn{5}{|l|}{ Longest Available Sample Simulations } \\
\hline MSCI Returns between $0 \%$ and $-1 \%$ & $-0.30 \%$ & $-0.25 \%$ & $2.24 * *$ & 7,292 \\
\hline MSCI Returns between -1\% and -5\% & $-1.50 \%$ & $-1.48 \%$ & 0.81 & 14,342 \\
\hline MSCI Returns between $-5 \%$ and $-10 \%$ & $-4.06 \%$ & $-4.35 \%$ & $-2.11 * *$ & 1,297 \\
\hline MSCI Returns less than $-10 \%$ & $-3.65 \%$ & $-3.74 \%$ & -0.40 & 287 \\
\hline \multicolumn{5}{|l|}{ Maximizing Expected Returns } \\
\hline \multicolumn{5}{|l|}{ Largest Number of Funds Simulations } \\
\hline MSCI Returns between $0 \%$ and $-1 \%$ & $-0.37 \%$ & $-0.29 \%$ & $2.63 * * *$ & 4,878 \\
\hline MSCI Returns between $-1 \%$ and $-5 \%$ & $-1.53 \%$ & $-1.61 \%$ & $-3.27 * * *$ & 10,193 \\
\hline MSCI Returns between -5\% and -10\% & $-4.00 \%$ & $-4.65 \%$ & $-4.22 * * *$ & 950 \\
\hline MSCI Returns less than $-10 \%$ & $-3.42 \%$ & $-3.70 \%$ & -0.96 & 191 \\
\hline \multicolumn{5}{|l|}{ Longest Available Sample Simulations } \\
\hline MSCI Returns between $0 \%$ and $-1 \%$ & $-0.30 \%$ & $-0.27 \%$ & 1.39 & 7,292 \\
\hline MSCI Returns between $-1 \%$ and $-5 \%$ & $-1.50 \%$ & $-1.59 \%$ & $-4.10 * * *$ & 14,342 \\
\hline MSCI Returns between -5\% and -10\% & $-4.06 \%$ & $-4.65 \%$ & $-4.38 * * *$ & 1,297 \\
\hline MSCI Returns less than $-10 \%$ & $-3.65 \%$ & $-4.11 \%$ & $-1.88 *$ & 287 \\
\hline \multicolumn{5}{|c|}{$\begin{array}{l}\text { This table shows the average returns of both global funds and simulated global funds conditional on negative returns on the MSCI } \\
\text { Emerging Market Index. Simulated global funds are constructed from actual global funds and specialized funds in the same mutual fund } \\
\text { family using two different procedures. The top part shows the results of minimizing the variance of returns subject to a restriction on the } \\
\text { expected return. The bottom part shows the results of maximizing expected returns subject to a restriction on the variance of returns. } \\
\text { Simulations are performed on daily returns. Aggregate weekly (Wednesday) returns are reported. Simulations using portfolios that } \\
\text { include the largest number of available specialized funds for each global fund in each family and using portfolios that include the longest } \\
\text { time series for each global fund in each family are displayed. T-statistics for the test of equality of means are shown. A positive t-statistic } \\
\text { means that returns of the simulated global fund are larger than those of global funds. }\end{array}$} \\
\hline
\end{tabular}


Table 17. Average Returns Conditional on Simulated Global Fund Returns

\begin{tabular}{|c|c|c|c|c|}
\hline & \multicolumn{2}{|c|}{ Average Returns (Per Week) } & \multirow[b]{2}{*}{$\begin{array}{c}\text { T-test: } \\
(P)=(G)\end{array}$} & \multirow[b]{2}{*}{$\begin{array}{c}\text { Number of } \\
\text { Observations }\end{array}$} \\
\hline & $\begin{array}{c}\text { Global Funds } \\
\text { (G) } \\
\end{array}$ & $\begin{array}{c}\text { Simulated } \\
\text { Global Funds } \\
(\mathrm{P}) \\
\end{array}$ & & \\
\hline \multicolumn{5}{|l|}{ Minimizing the Variance } \\
\hline \multicolumn{5}{|l|}{ Largest Number of Funds Simulations } \\
\hline Simulated Global Fund Returns between $0 \%$ and $-1 \%$ & $-0.52 \%$ & $-0.48 \%$ & $4.03 * * *$ & 6,380 \\
\hline Simulated Global Fund Returns between $-1 \%$ and $-5 \%$ & $-2.21 \%$ & $-2.18 \%$ & $2.08 * *$ & 8,946 \\
\hline Simulated Global Fund Returns between $-5 \%$ and $-10 \%$ & $-6.06 \%$ & $-6.36 \%$ & $-2.63 * * *$ & 582 \\
\hline Simulated Global Fund Returns less than $-10 \%$ & $-11.71 \%$ & $-12.51 \%$ & -1.57 & 99 \\
\hline \multicolumn{5}{|l|}{ Longest Available Sample Simulations } \\
\hline Simulated Global Fund Returns between $0 \%$ and $-1 \%$ & $-0.49 \%$ & $-0.47 \%$ & $2.93 * * *$ & 9,340 \\
\hline Simulated Global Fund Returns between $-1 \%$ and $-5 \%$ & $-2.22 \%$ & $-2.19 \%$ & $1.89 *$ & 12,529 \\
\hline Simulated Global Fund Returns between $-5 \%$ and $-10 \%$ & $-6.23 \%$ & $-6.37 \%$ & $-1.69 *$ & 907 \\
\hline Simulated Global Fund Returns less than $-10 \%$ & $-11.89 \%$ & $-12.74 \%$ & $-2.08 * *$ & 156 \\
\hline \multicolumn{5}{|l|}{ Maximizing Expected Returns } \\
\hline \multicolumn{5}{|l|}{ Largest Number of Funds Simulations } \\
\hline Simulated Global Fund Returns between $0 \%$ and $-1 \%$ & $-0.49 \%$ & $-0.47 \%$ & 1.32 & 6,183 \\
\hline Simulated Global Fund Returns between $-1 \%$ and $-5 \%$ & $-2.14 \%$ & $-2.22 \%$ & $-4.43 * * *$ & 9,265 \\
\hline Simulated Global Fund Returns between $-5 \%$ and $-10 \%$ & $-5.69 \%$ & $-6.23 \%$ & $-4.84 * * *$ & 631 \\
\hline Simulated Global Fund Returns less than $-10 \%$ & $-11.52 \%$ & $-12.47 \%$ & $-2.14 * *$ & 100 \\
\hline \multicolumn{5}{|l|}{ Longest Available Sample Simulations } \\
\hline Simulated Global Fund Returns between $0 \%$ and $-1 \%$ & $-0.47 \%$ & $-0.47 \%$ & 0.02 & 9,079 \\
\hline Simulated Global Fund Returns between $-1 \%$ and $-5 \%$ & $-2.16 \%$ & $-2.21 \%$ & $-3.76 * * *$ & 12,854 \\
\hline Simulated Global Fund Returns between $-5 \%$ and $-10 \%$ & $-6.01 \%$ & $-6.27 \%$ & $-2.96 * * *$ & 963 \\
\hline Simulated Global Fund Returns less than $-10 \%$ & $-12.04 \%$ & $-12.41 \%$ & -1.01 & 146 \\
\hline
\end{tabular}

This table shows the average returns for both global funds and simulated global funds conditional on negative returns on the simulated global fund. Simulated global funds are constructed from actual global funds and specialized funds in the same mutual fund family using two different procedures. The top part shows the results of minimizing the variance of returns subject to a restriction on the expected return. The bottom part shows the results of maximizing expected returns subject to a restriction on the variance of returns. Simulations are performed on daily returns. Aggregate weekly (Wednesday) returns are reported. Simulations using portfolios that include the largest number of available specialized funds for each global fund in each family and using portfolios that include the longest time series for each global fund in each family are displayed. Tstatistics for the test of equality of means are shown. A positive t-statistic means that returns of the simulated global fund are larger than those of global funds. 
Table 18. Average Returns Conditional on Global Fund Returns

\section{Minimizing the Variance}

Largest Number of Funds Simulations

Global Fund Returns between $0 \%$ and -1\%

Global Fund Returns between -1\% and -5\%

Global Fund Returns between $-5 \%$ and $-10 \%$

Global Fund Returns less than $-10 \%$

Longest Available Sample Simulations

Global Fund Returns between $0 \%$ and $-1 \%$

Global Fund Returns between -1\% and -5\%

Global Fund Returns between -5\% and -10\%

Global Fund Returns less than $-10 \%$

\section{Maximizing Expected Returns}

\section{Largest Number of Funds Simulations}

Global Fund Returns between 0\% and -1\%

Global Fund Returns between -1\% and -5\%

Global Fund Returns between - $5 \%$ and $-10 \%$

Global Fund Returns less than $-10 \%$

\section{Longest Available Sample Simulations}

Global Fund Returns between $0 \%$ and $-1 \%$

Global Fund Returns between -1\% and -5\%

Global Fund Returns between -5\% and -10\%

Global Fund Returns less than $-10 \%$

\begin{tabular}{|c|c|c|}
\hline \multicolumn{2}{|c|}{ Average Returns (Per Week) } & \\
\hline & Simulated & \multirow[b]{2}{*}{$\begin{array}{l}\text { T-test: } \\
(\mathrm{P})=(\mathrm{G})\end{array}$} \\
\hline $\begin{array}{c}\text { Global Funds } \\
\text { (G) }\end{array}$ & $\begin{array}{c}\text { Global Funds } \\
\text { (P) }\end{array}$ & \\
\hline
\end{tabular}

Number of Observations

$\begin{array}{ccrc}-0.47 \% & -0.34 \% & 11.74 * * * & 6,371 \\ -2.23 \% & -1.91 \% & 19.92 * * * & 9,273 \\ -6.36 \% & -5.25 \% & 13.83 * * * & 784 \\ -13.02 \% & -10.84 \% & 4.57 * * * & 113 \\ & & & \\ -0.47 \% & -0.37 \% & 11.94 * * * & 9,297 \\ -2.23 \% & -1.99 \% & 17.56 * * * & 12,840 \\ -6.46 \% & -5.55 \% & 13.60 * * * & 1,140 \\ -13.24 \% & -11.36 \% & 4.89 * * * & 163\end{array}$

$\begin{array}{lcrc}-0.47 \% & -0.36 \% & 8.68 * * * & 6,371 \\ -2.23 \% & -1.98 \% & 15.00 * * * & 9,273 \\ -6.36 \% & -5.22 \% & 13.61 * * * & 784 \\ -13.02 \% & -10.37 \% & 5.89 * * * & 113 \\ & & & \\ -0.47 \% & -0.40 \% & 8.14 * * * & 9,297 \\ -2.23 \% & -2.02 \% & 15.01 * * * & 12,840 \\ -6.46 \% & -5.43 \% & 15.29 * * * & 1,140 \\ -13.24 \% & -10.84 \% & 6.80 * * * & 163\end{array}$

This table shows the average returns for both global funds and simulated global funds conditional on negative returns on the global funds. Simulated global funds are constructed from actual global funds and specialized funds in the same mutual fund family using two different procedures. The top part shows the results of minimizing the variance of returns subject to a restriction on the expected return. The bottom part shows the results of maximizing expected returns subject to a restriction on the variance of returns. Simulations are performed on daily returns. Aggregate weekly (Wednesday) returns are reported. Simulations using portfolios that include the largest number of available specialized funds for each global fund in each family and using portfolios that include the longest time series for each global fund in each family are displayed. T-statistics for the test of equality of means are shown. A positive t-statistic means that returns of the simulated global fund are larger than those of global funds. 
Appendix Table 1. Price Data on Mutual Funds

\begin{tabular}{|c|c|c|c|c|}
\hline & \multirow[b]{2}{*}{ Mutual Fund Family } & \multirow{2}{*}{$\begin{array}{c}\text { Number of } \\
\text { Funds } \\
\end{array}$} & \multicolumn{2}{|c|}{ Sample } \\
\hline & & & Beginning & End \\
\hline 1 & AIM Family of Funds & 17 & Apr. 92 & Jul. 05 \\
\hline 2 & Alliance Bernstein & 10 & Dec. 99 & Jun. 06 \\
\hline 3 & Allianz Funds & 4 & Dec. 04 & Jul. 05 \\
\hline 4 & American Funds Group & 7 & Mar. 02 & Jun. 06 \\
\hline 5 & Columbia Funds & 8 & Oct. 00 & Jun. 06 \\
\hline 6 & Credit Suisse & 8 & Dec. 01 & Jun. 06 \\
\hline 7 & DFA Investment Dimensions Group & 9 & Mar. 93 & Jul. 05 \\
\hline 8 & Dreyfus Founders & 11 & Jul. 96 & Jun. 06 \\
\hline 9 & Eaton Vance Group & 7 & Sep. 99 & Jul. 05 \\
\hline 10 & Evergreen Funds & 5 & Sep. 94 & Jun. 06 \\
\hline 11 & Excelsior Funds & 4 & Sep. 93 & Jul. 05 \\
\hline 12 & Fidelity Advisors Funds & 14 & Dec. 00 & Jun. 06 \\
\hline 13 & Fidelity Group & 18 & Sep. 89 & Jul. 05 \\
\hline 14 & GAM Funds & 7 & Jan. 90 & Jul. 05 \\
\hline 15 & Gartmore & 5 & Jul. 04 & Jun. 06 \\
\hline 16 & GMO LLC & 17 & Jan. 99 & Jul. 05 \\
\hline 17 & Goldman Sachs Asset Management Group & 11 & Oct. 98 & Jul. 05 \\
\hline 18 & Hartford Mutual Funds & 10 & May 01 & Jun. 06 \\
\hline 19 & ING Funds Trust & 12 & Nov. 94 & Jul. 05 \\
\hline 20 & Ivy Mackenzie Management & 9 & May 99 & Jul. 05 \\
\hline 21 & J.P. Morgan Funds & 10 & Jul. 02 & Jun. 06 \\
\hline 22 & Janus & 12 & Oct. 98 & Jun. 06 \\
\hline 23 & Merrill Lynch Group & 15 & Nov. 94 & Jul. 05 \\
\hline 24 & MFS Family of Funds & 11 & Jun. 96 & Jun. 06 \\
\hline 25 & Morgan Stanley Funds & 26 & Oct. 94 & Jul. 05 \\
\hline 26 & Oppenheimer Funds & 9 & Sep. 04 & Jun. 06 \\
\hline 27 & Putnam Funds & 6 & Nov. 91 & Jul. 05 \\
\hline 28 & RiverSource (former AXP) & 9 & Jul. 90 & Jul. 05 \\
\hline 29 & Scudder Funds & 18 & Jun. 98 & Jul. 05 \\
\hline 30 & Seligman Group & 4 & Jun. 03 & Jun. 06 \\
\hline 31 & Smith Barney Group & 6 & Mar. 98 & Jun. 06 \\
\hline 32 & T. Rowe Price Funds & 14 & Jun. 92 & Jul. 05 \\
\hline 33 & Templeton Group & 20 & Nov. 92 & Jul. 05 \\
\hline 34 & UBS Funds & 6 & Mar. 01 & Jun. 06 \\
\hline 35 & Vanguard Group & 11 & Jul. 00 & Jun. 06 \\
\hline 36 & Wells Fargo Advantage & 5 & Oct. 97 & Jul. 05 \\
\hline
\end{tabular}

This table describes the number of funds and the beginning and the end of the price data sample for each mutual fund family. The data source is Bloomberg. 
Appendix Table 2. Probabilities of Being Held by a Mutual Fund (World Funds and Foreign Funds)

Total Holdings

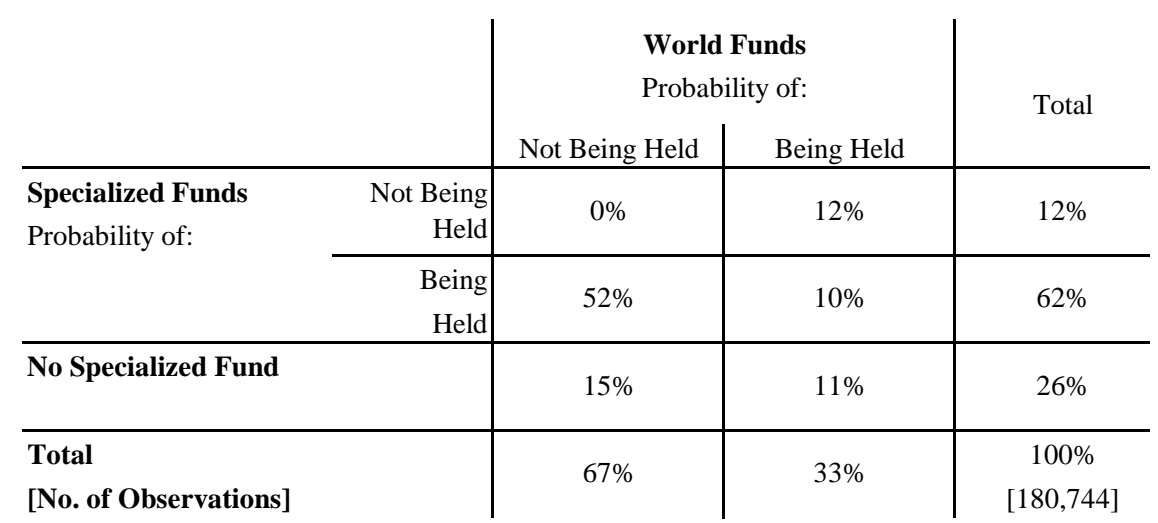

\begin{tabular}{|c|c|c|c|c|}
\hline & \multicolumn{2}{|c|}{$\begin{array}{l}\text { Foreign Funds } \\
\text { Probability of: }\end{array}$} & \multirow{2}{*}{ Total } \\
\hline & & Not Being Held & Being Held & \\
\hline \multirow{3}{*}{$\begin{array}{l}\text { Specialized Funds } \\
\text { Probability of: }\end{array}$} & Not Being & \multirow{2}{*}{$0 \%$} & \multirow{2}{*}{$23 \%$} & \multirow{2}{*}{$23 \%$} \\
\hline & Held & & & \\
\hline & $\begin{array}{r}\text { Being } \\
\text { Held } \\
\end{array}$ & $34 \%$ & $15 \%$ & $49 \%$ \\
\hline \multicolumn{2}{|l|}{ No Specialized Fund } & $2 \%$ & $26 \%$ & $28 \%$ \\
\hline \multicolumn{2}{|l|}{$\begin{array}{l}\text { Total } \\
\text { [No. of Observations] }\end{array}$} & $36 \%$ & $64 \%$ & $\begin{array}{c}100 \% \\
{[379,913]}\end{array}$ \\
\hline
\end{tabular}

Holdings in Developing Countries Only

\begin{tabular}{|c|c|c|c|c|}
\hline & & \multicolumn{2}{|c|}{$\begin{array}{l}\text { World Funds } \\
\text { Probability of: }\end{array}$} & \multirow{2}{*}{ Total } \\
\hline & & Not Being Held & Being Held & \\
\hline \multirow{3}{*}{$\begin{array}{l}\text { Specialized Funds } \\
\text { Probability of: }\end{array}$} & Not Being & $0 \%$ & $5 \%$ & $5 \%$ \\
\hline & Held & & & \\
\hline & $\begin{array}{r}\text { Being } \\
\text { Held }\end{array}$ & $83 \%$ & $9 \%$ & $92 \%$ \\
\hline No Specialized Fund & & $1 \%$ & $1 \%$ & $3 \%$ \\
\hline $\begin{array}{l}\text { Total } \\
\text { [No. of Observations] }\end{array}$ & & $85 \%$ & $15 \%$ & $\begin{array}{c}100 \% \\
{[45,458]}\end{array}$ \\
\hline
\end{tabular}

\begin{tabular}{|c|c|c|c|c|}
\hline & \multicolumn{2}{|c|}{$\begin{array}{l}\text { Foreign Funds } \\
\text { Probability of: }\end{array}$} & \multirow[t]{2}{*}{ Total } \\
\hline & & Not Being Held & Being Held & \\
\hline \multirow{3}{*}{$\begin{array}{l}\text { Specialized Funds } \\
\text { Probability of: }\end{array}$} & Not Being & \multirow{2}{*}{$0 \%$} & \multirow{2}{*}{$8 \%$} & \multirow{2}{*}{$8 \%$} \\
\hline & Held & & & \\
\hline & $\begin{array}{r}\text { Being } \\
\text { Held } \\
\end{array}$ & $79 \%$ & $12 \%$ & $90 \%$ \\
\hline No Specialized Fund & & $0 \%$ & $1 \%$ & $2 \%$ \\
\hline $\begin{array}{l}\text { Total } \\
\text { [No. of Observations] }\end{array}$ & & $79 \%$ & $21 \%$ & $\begin{array}{c}100 \% \\
{[89,272]}\end{array}$ \\
\hline
\end{tabular}

This table shows frequency counts for mutual fund stock holdings from 1997 to 2005 . The reported numbers correspond to the probability of being held (or not) by certain types of mutual funds, given that a mutual fund family has both fund types. The top panel includes stock holdings in all countries except the U.S., whereas the bottom panel includes stock holdings in developing countries only. Each observation is a family-year-stock observation. The total number of observations is reported in brackets in the "Total" row of each table. When a world fund or a foreign fund in a given familyyear holds a stock in a country not covered by the specialized funds within that family in that year, this observation is counted in the "No Specialized Fund" row. Specialized funds include: emerging market funds, regional funds, and country funds. 
Appendix Table 3. Portfolio Choice of Mutual Funds: Importance of Family Effects

\begin{tabular}{|c|c|c|c|c|c|c|}
\hline & \multicolumn{3}{|c|}{ Dependent Variable: Number of Holdings } & \multicolumn{3}{|c|}{ Dependent Variable: Percentage of Net Assets in Top Ten Holdings } \\
\hline & (1) & (2) & (3) & (4) & (5) & (6) \\
\hline \multicolumn{7}{|l|}{ Independent Variables } \\
\hline \multirow[t]{2}{*}{ Number of Managers } & $17.020 * * *$ & $16.440 * * *$ & 4.773 & $-0.625 * * *$ & $-0.626 * * *$ & $-0.288 *$ \\
\hline & [4.946] & [4.859] & [3.775] & {$[0.155]$} & {$[0.157]$} & {$[0.150]$} \\
\hline \multirow[t]{2}{*}{ Manager Tenure } & 2.145 & 1.268 & $2.338 *$ & -0.018 & -0.020 & $-0.172 * *$ \\
\hline & {$[2.480]$} & {$[2.250]$} & [1.282] & {$[0.123]$} & {$[0.122]$} & [0.085] \\
\hline \multirow[t]{2}{*}{ Fund Age } & -0.212 & 0.173 & -1.276 & $-0.100 * *$ & $-0.099 * *$ & $-0.104 * *$ \\
\hline & {$[0.831]$} & {$[0.849]$} & {$[0.850]$} & {$[0.048]$} & {$[0.048]$} & {$[0.049]$} \\
\hline \multirow[t]{2}{*}{ Fund Expenses } & $0.432 * * *$ & $-2.211 *$ & 0.278 & $-0.029 * * *$ & -0.035 & $-0.076 * *$ \\
\hline & {$[0.116]$} & [1.269] & {$[0.461]$} & {$[0.007]$} & {$[0.049]$} & {$[0.036]$} \\
\hline \multirow[t]{2}{*}{ Fund Size } & & $0.026 * *$ & 0.001 & & 0.000 & $0.001 * *$ \\
\hline & & {$[0.013]$} & {$[0.005]$} & & {$[0.000]$} & {$[0.000]$} \\
\hline Year Dummies & Yes & Yes & Yes & Yes & Yes & Yes \\
\hline Fund Type Dummies & Yes & Yes & Yes & Yes & Yes & Yes \\
\hline Family Dummies & No & No & Yes & No & No & Yes \\
\hline No. of Observations & 5,662 & 5,662 & 5,662 & 5,649 & 5,649 & 5,649 \\
\hline R-squared & 0.06 & 0.07 & 0.52 & 0.15 & 0.15 & 0.47 \\
\hline
\end{tabular}

This table reports regressions of the number of stock holdings and the percentage of net assets in the top ten stock holdings on the number of managers, manager tenure, fund age, fund expenses, and fund size. Depending on the specification, year and/or fund type dummies are included. The sample period is 1997-2005. Fund expenses and fund size are in millions of U.S. dollars. Fund age is expressed in years.

Standard errors are clustered at the family level. Standard deviations are shown in brackets. ***, **, and * indicate significance at one, five, and ten percent, respectively. 
Appendix Table 4A. Family Simulations Using the Largest Number of Funds

\begin{tabular}{|c|c|c|c|c|c|c|c|}
\hline & \multirow[b]{3}{*}{ Mutual Fund Family } & \multicolumn{6}{|c|}{ Minimizing the Variance } \\
\hline & & \multicolumn{2}{|c|}{$\begin{array}{l}\text { Average Returns } \\
\text { (Per Year) }\end{array}$} & \multirow{2}{*}{$\begin{array}{c}\text { Average } \\
\text { Difference in } \\
\text { Accumulated } \\
\text { Daily Returns }\end{array}$} & \multicolumn{2}{|c|}{$\begin{array}{l}\text { Standard Deviation } \\
\text { of Daily Returns }\end{array}$} & \multirow[b]{2}{*}{$\begin{array}{c}\text { Number of } \\
\text { Comparisons }\end{array}$} \\
\hline & & $\begin{array}{l}\text { Global } \\
\text { Funds }\end{array}$ & $\begin{array}{c}\text { Simulated Global } \\
\text { Funds }\end{array}$ & & $\begin{array}{l}\text { Global } \\
\text { Funds }\end{array}$ & $\begin{array}{c}\text { Simulated Global } \\
\text { Funds }\end{array}$ & \\
\hline 1 & Allianz Funds & $0.95 \%$ & $-3.05 \%$ & $-3.91 \%$ & $0.66 \%$ & $0.65 \%$ & 2 \\
\hline 2 & Alliance Bernstein & $11.01 \%$ & $12.90 \%$ & $1.77 \%$ & $0.81 \%$ & $0.79 \%$ & 8 \\
\hline 3 & American Funds Group & $10.57 \%$ & $13.93 \%$ & $3.33 \%$ & $0.87 \%$ & $0.74 \%$ & 4 \\
\hline 4 & AIM Family of Funds & $9.53 \%$ & $22.55 \%$ & $12.37 \%$ & $0.90 \%$ & $0.76 \%$ & 10 \\
\hline 5 & Columbia Funds & $17.58 \%$ & $21.08 \%$ & $3.28 \%$ & $0.85 \%$ & $0.77 \%$ & 3 \\
\hline 6 & Credit Suisse & $8.46 \%$ & $12.15 \%$ & $3.63 \%$ & $0.95 \%$ & $0.85 \%$ & 2 \\
\hline 7 & DFA Investment Dimensions Group & $2.97 \%$ & $1.13 \%$ & $-1.64 \%$ & $0.91 \%$ & $0.85 \%$ & 4 \\
\hline 8 & Dreyfus Founders & $8.94 \%$ & $15.90 \%$ & $6.66 \%$ & $0.87 \%$ & $0.80 \%$ & 6 \\
\hline 9 & Evergreen Funds & $3.25 \%$ & $1.69 \%$ & $-1.21 \%$ & $1.12 \%$ & $1.02 \%$ & 2 \\
\hline 10 & Eaton Vance Group & $5.63 \%$ & $22.13 \%$ & $16.40 \%$ & $1.01 \%$ & $0.71 \%$ & 2 \\
\hline 11 & Excelsior Funds & $3.95 \%$ & $7.15 \%$ & $3.13 \%$ & $0.89 \%$ & $0.87 \%$ & 2 \\
\hline 12 & Fidelity Group & $5.80 \%$ & $9.46 \%$ & $3.78 \%$ & $1.03 \%$ & $0.94 \%$ & 6 \\
\hline 13 & Fidelity Advisors Funds & $7.76 \%$ & $11.71 \%$ & $3.96 \%$ & $0.87 \%$ & $0.76 \%$ & 6 \\
\hline 14 & GAM Funds & $-7.63 \%$ & $-3.88 \%$ & $4.40 \%$ & $1.08 \%$ & $0.96 \%$ & 2 \\
\hline 15 & Gartmore & $22.30 \%$ & $18.99 \%$ & $-2.62 \%$ & $0.81 \%$ & $0.78 \%$ & 3 \\
\hline 16 & GMO LLC & $6.65 \%$ & $8.05 \%$ & $1.36 \%$ & $0.76 \%$ & $0.77 \%$ & 8 \\
\hline 17 & Goldman Sachs Asset Management Group & $1.63 \%$ & $7.18 \%$ & $5.84 \%$ & $1.03 \%$ & $0.91 \%$ & 6 \\
\hline 18 & Hartford Mutual Funds & $10.41 \%$ & $13.49 \%$ & $3.11 \%$ & $0.98 \%$ & $0.84 \%$ & 2 \\
\hline 19 & ING Funds Trust & $-5.75 \%$ & $-1.34 \%$ & $5.33 \%$ & $1.12 \%$ & $1.01 \%$ & 6 \\
\hline 20 & Ivy Mackenzie Management & $1.35 \%$ & $4.81 \%$ & $3.77 \%$ & $0.89 \%$ & $0.76 \%$ & 4 \\
\hline 21 & Janus & $-7.01 \%$ & $0.08 \%$ & $7.60 \%$ & $0.67 \%$ & $0.70 \%$ & 5 \\
\hline 22 & J.P. Morgan Funds & $22.11 \%$ & $24.06 \%$ & $1.68 \%$ & $0.90 \%$ & $0.87 \%$ & 4 \\
\hline 23 & MFS Family of Funds & $20.70 \%$ & $39.09 \%$ & $15.93 \%$ & $0.88 \%$ & $0.81 \%$ & 3 \\
\hline 24 & Merrill Lynch Group & $10.31 \%$ & $12.78 \%$ & $2.49 \%$ & $1.01 \%$ & $0.93 \%$ & 9 \\
\hline 25 & Morgan Stanley Funds & $1.23 \%$ & $4.47 \%$ & $3.61 \%$ & $1.01 \%$ & $0.88 \%$ & 11 \\
\hline 26 & Oppenheimer Funds & $9.04 \%$ & $9.06 \%$ & $-0.03 \%$ & $0.80 \%$ & $0.84 \%$ & 4 \\
\hline 27 & Putnam Funds & $4.86 \%$ & $5.53 \%$ & $0.74 \%$ & $1.08 \%$ & $1.05 \%$ & 5 \\
\hline 28 & RiverSource (former AXP) & $13.45 \%$ & $22.06 \%$ & $7.87 \%$ & $0.84 \%$ & $0.73 \%$ & 2 \\
\hline 29 & Scudder Funds & $8.56 \%$ & $14.60 \%$ & $5.85 \%$ & $0.97 \%$ & $0.86 \%$ & 9 \\
\hline 30 & Smith Barney Group & $8.79 \%$ & $9.81 \%$ & $0.90 \%$ & $0.72 \%$ & $0.74 \%$ & 1 \\
\hline 31 & Seligman Group & $14.45 \%$ & $15.89 \%$ & $1.26 \%$ & $0.82 \%$ & $0.82 \%$ & 2 \\
\hline 32 & Templeton Group & $-3.58 \%$ & $-0.94 \%$ & $3.04 \%$ & $0.89 \%$ & $0.77 \%$ & 9 \\
\hline 33 & T. Rowe Price Funds & $24.48 \%$ & $38.61 \%$ & $11.47 \%$ & $0.82 \%$ & $0.80 \%$ & 6 \\
\hline 34 & UBS Funds & $4.41 \%$ & $7.30 \%$ & $2.88 \%$ & $0.89 \%$ & $0.84 \%$ & 1 \\
\hline 35 & Vanguard Group & $7.77 \%$ & $10.39 \%$ & $2.54 \%$ & $0.96 \%$ & $0.92 \%$ & 4 \\
\hline \multirow[t]{2}{*}{36} & Wells Fargo Advantage & $5.22 \%$ & $11.69 \%$ & $6.65 \%$ & $0.98 \%$ & $0.78 \%$ & 2 \\
\hline & Total & $6.78 \%$ & $11.14 \%$ & $4.42 \%$ & $0.92 \%$ & $0.84 \%$ & 165 \\
\hline $\begin{array}{l}\text { retu } \\
\text { fore }\end{array}$ & $\begin{array}{l}\text { le shows differences in the average and sta } \\
\text { structed from actual global funds and spec } \\
\text { The simulations use portfolios that includ } \\
\text { funds, and a pool of world or foreign funds } \\
\text { different scopes, e.g. world (foreign) valu } \\
\text { ulated out-of-sample, as described in the } \\
\text { ed. Averages across simulations are then co }\end{array}$ & $\begin{array}{l}\text { lized fur } \\
\text { the larg } \\
\text { The pool } \\
\text { unds an }\end{array}$ & $\begin{array}{l}\text { nber of available s } \\
\text { the same mutd or foreign fund } \\
\text { (foreign) growth }\end{array}$ & $\begin{array}{l}\text { zed funds for } \\
\text { imulations that } \\
\text { imortfolio weigh }\end{array}$ & $\begin{array}{l}\text { varian } \\
\text { bal fun } \\
\text { severa } \\
\text { pdated }\end{array}$ & $\begin{array}{l}\text { ach family. Global } \\
\text { eturns subject to a } \\
\text { Realized returns of }\end{array}$ & $\begin{array}{l}\text { lated global fu } \\
\text { ction on expec } \\
\text { s are world fun } \\
\text { in the same fan } \\
\text { mulated portfol } \\
\text { r each simulat }\end{array}$ \\
\hline
\end{tabular}


Appendix Table 4B. Family Simulations Using the Largest Number of Funds

\begin{tabular}{|c|c|c|c|c|c|c|c|}
\hline & \multirow[b]{3}{*}{ Mutual Fund Family } & \multicolumn{6}{|c|}{ Maximizing Expected Returns } \\
\hline & & \multicolumn{2}{|c|}{$\begin{array}{c}\text { Average Returns } \\
\text { (Per Year) }\end{array}$} & \multirow{2}{*}{$\begin{array}{c}\text { Average } \\
\text { Difference in } \\
\text { Accumulated Daily } \\
\text { Returns } \\
\end{array}$} & \multicolumn{2}{|c|}{$\begin{array}{l}\text { Standard Deviation } \\
\text { of Daily Returns }\end{array}$} & \multirow[b]{2}{*}{$\begin{array}{c}\text { Number of } \\
\text { Comparisons }\end{array}$} \\
\hline & & $\begin{array}{l}\text { Global } \\
\text { Funds }\end{array}$ & $\begin{array}{c}\text { Simulated Global } \\
\text { Funds }\end{array}$ & & $\begin{array}{l}\text { Global } \\
\text { Funds }\end{array}$ & $\begin{array}{c}\text { Simulated Global } \\
\text { Funds }\end{array}$ & \\
\hline 1 & Allianz Funds & $0.95 \%$ & $-3.95 \%$ & $-4.79 \%$ & $0.66 \%$ & $0.65 \%$ & 2 \\
\hline 2 & Alliance Bernstein & $11.01 \%$ & $13.53 \%$ & $2.32 \%$ & $0.81 \%$ & $0.79 \%$ & 8 \\
\hline 3 & American Funds Group & $10.57 \%$ & $11.76 \%$ & $1.22 \%$ & $0.87 \%$ & $0.81 \%$ & 4 \\
\hline 4 & AIM Family of Funds & $9.53 \%$ & $18.65 \%$ & $8.69 \%$ & $0.90 \%$ & $0.79 \%$ & 10 \\
\hline 5 & Columbia Funds & $17.58 \%$ & $20.34 \%$ & $2.53 \%$ & $0.85 \%$ & $0.78 \%$ & 3 \\
\hline 6 & Credit Suisse & $8.46 \%$ & $10.91 \%$ & $2.40 \%$ & $0.95 \%$ & $0.89 \%$ & 2 \\
\hline 7 & DFA Investment Dimensions Group & $2.97 \%$ & $1.52 \%$ & $-1.13 \%$ & $0.91 \%$ & $0.78 \%$ & 4 \\
\hline 8 & Dreyfus Founders & $8.94 \%$ & $15.23 \%$ & $5.96 \%$ & $0.87 \%$ & $0.83 \%$ & 6 \\
\hline 9 & Evergreen Funds & $3.25 \%$ & $5.20 \%$ & $2.53 \%$ & $1.12 \%$ & $0.91 \%$ & 2 \\
\hline 10 & Eaton Vance Group & $5.63 \%$ & $20.00 \%$ & $14.34 \%$ & $1.01 \%$ & $0.73 \%$ & 2 \\
\hline 11 & Excelsior Funds & $3.95 \%$ & $11.10 \%$ & $6.92 \%$ & $0.89 \%$ & $0.87 \%$ & 2 \\
\hline 12 & Fidelity Group & $5.80 \%$ & $9.65 \%$ & $3.69 \%$ & $1.03 \%$ & $1.03 \%$ & 6 \\
\hline 13 & Fidelity Advisors Funds & $7.76 \%$ & $11.79 \%$ & $3.86 \%$ & $0.87 \%$ & $0.83 \%$ & 6 \\
\hline 14 & GAM Funds & $-7.63 \%$ & $-2.36 \%$ & $6.01 \%$ & $1.08 \%$ & $0.97 \%$ & 2 \\
\hline 15 & Gartmore & $22.30 \%$ & $18.99 \%$ & $-2.66 \%$ & $0.81 \%$ & $0.80 \%$ & 3 \\
\hline 16 & GMO LLC & $6.65 \%$ & $9.26 \%$ & $2.41 \%$ & $0.76 \%$ & $0.80 \%$ & 8 \\
\hline 17 & Goldman Sachs Asset Management Group & $1.63 \%$ & $4.30 \%$ & $2.83 \%$ & $1.03 \%$ & $0.97 \%$ & 6 \\
\hline 18 & Hartford Mutual Funds & $10.41 \%$ & $13.92 \%$ & $3.44 \%$ & $0.98 \%$ & $0.87 \%$ & 2 \\
\hline 19 & ING Funds Trust & $-5.75 \%$ & $6.60 \%$ & $14.46 \%$ & $1.12 \%$ & $1.06 \%$ & 6 \\
\hline 20 & Ivy Mackenzie Management & $1.35 \%$ & $5.22 \%$ & $4.14 \%$ & $0.89 \%$ & $0.81 \%$ & 4 \\
\hline 21 & Janus & $-7.01 \%$ & $3.76 \%$ & $11.31 \%$ & $0.67 \%$ & $0.82 \%$ & 5 \\
\hline 22 & J.P. Morgan Funds & $22.11 \%$ & $23.09 \%$ & $0.88 \%$ & $0.90 \%$ & $0.87 \%$ & 4 \\
\hline 23 & MFS Family of Funds & $20.70 \%$ & $25.94 \%$ & $4.49 \%$ & $0.88 \%$ & $0.83 \%$ & 3 \\
\hline 24 & Merrill Lynch Group & $10.31 \%$ & $14.14 \%$ & $3.76 \%$ & $1.01 \%$ & $0.92 \%$ & 9 \\
\hline 25 & Morgan Stanley Funds & $1.23 \%$ & $6.50 \%$ & $5.52 \%$ & $1.01 \%$ & $0.95 \%$ & 11 \\
\hline 26 & Oppenheimer Funds & $9.04 \%$ & $5.03 \%$ & $-3.87 \%$ & $0.80 \%$ & $0.91 \%$ & 4 \\
\hline 27 & Putnam Funds & $4.86 \%$ & $5.03 \%$ & $0.26 \%$ & $1.08 \%$ & $1.05 \%$ & 5 \\
\hline 28 & RiverSource (former AXP) & $13.45 \%$ & $19.31 \%$ & $5.39 \%$ & $0.84 \%$ & $0.76 \%$ & 2 \\
\hline 29 & Scudder Funds & $8.56 \%$ & $15.98 \%$ & $6.98 \%$ & $0.97 \%$ & $0.92 \%$ & 9 \\
\hline 30 & Smith Barney Group & $8.79 \%$ & $11.87 \%$ & $2.74 \%$ & $0.72 \%$ & $0.77 \%$ & 1 \\
\hline 31 & Seligman Group & $14.45 \%$ & $16.85 \%$ & $2.07 \%$ & $0.82 \%$ & $0.84 \%$ & 2 \\
\hline 32 & Templeton Group & $-3.58 \%$ & $-2.40 \%$ & $1.43 \%$ & $0.89 \%$ & $0.81 \%$ & 9 \\
\hline 33 & T. Rowe Price Funds & $24.48 \%$ & $35.82 \%$ & $9.19 \%$ & $0.82 \%$ & $0.81 \%$ & 6 \\
\hline 34 & UBS Funds & $4.41 \%$ & $6.71 \%$ & $2.27 \%$ & $0.89 \%$ & $0.85 \%$ & 1 \\
\hline 35 & Vanguard Group & $7.77 \%$ & $8.77 \%$ & $1.00 \%$ & $0.96 \%$ & $0.94 \%$ & 4 \\
\hline \multirow[t]{2}{*}{36} & Wells Fargo Advantage & $5.22 \%$ & $15.35 \%$ & $10.03 \%$ & $0.98 \%$ & $0.83 \%$ & 2 \\
\hline & Total & $6.78 \%$ & $11.12 \%$ & $4.34 \%$ & $0.92 \%$ & $0.87 \%$ & 165 \\
\hline & $\begin{array}{l}\text { ble shows differences in the average and st } \\
\text { istructed from actual global funds and spec } \\
\text { The simulations use portfolios that include } \\
\text { and a pool of world or foreign funds. The p } \\
\text { at scopes, e.g. world (foreign) value funds } \\
\text { ted out-of-sample, as described in the mair } \\
\text { es across simulations are then computed an }\end{array}$ & $\begin{array}{l}\text { ard devi } \\
\text { ized fun } \\
\text { e largest } \\
\text { s of wor } \\
\text { d world } \\
\text { xt. Annu } \\
\text { eported. }\end{array}$ & $\begin{array}{l}\text { of returns betweer } \\
\text { the same mutual } \\
\text { er of available spe } \\
\text { foreign funds are } \\
\text { ign) growth funds } \\
\text { d differences in a }\end{array}$ & $\begin{array}{l}\text { amily by maximizi } \\
\text { ed funds for each gl } \\
\text { tions that include se } \\
\text { folio weights are }\end{array}$ & $\begin{array}{l}\text { obal fu } \\
\text { pected } \\
\text { und in } \\
\text { world } \\
\text { d daily }\end{array}$ & $\begin{array}{l}\text { mutual fund family } \\
\text { subject to a restr } \\
\text { mily. Global funds } \\
\text { eign) funds within } \\
\text { zed returns of the }\end{array}$ & $\begin{array}{l}\text { ated global } \mathrm{ft} \\
\text { n the varianc } \\
\text { rld funds, for } \\
\text { e family but } \\
\text { ed portfolios }\end{array}$ \\
\hline
\end{tabular}


Appendix Table 5A. Family Simulations Using the Longest Available Sample

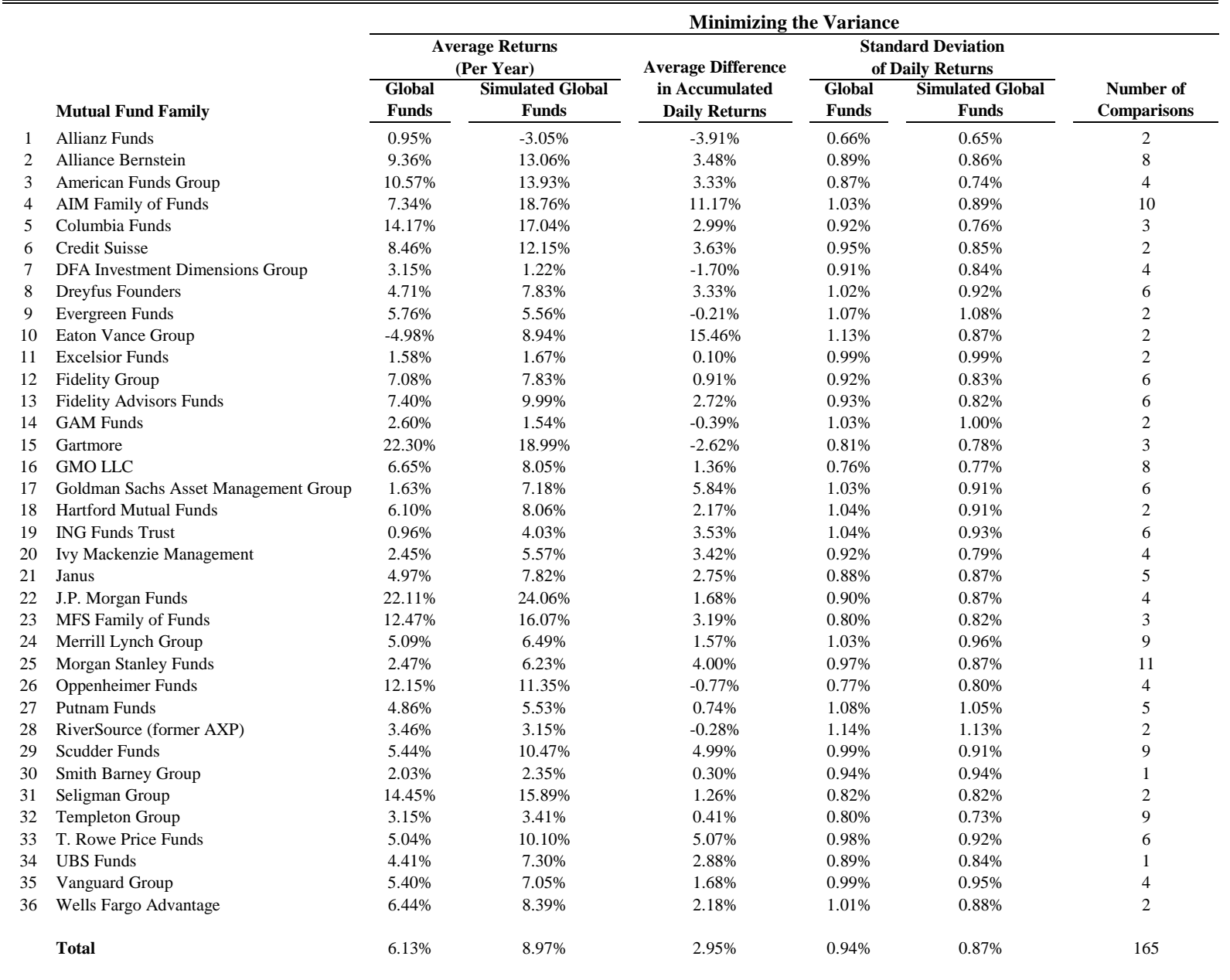

This table shows differences in the average and standard deviation of returns between global funds and simulated global funds by mutual fund family. Simulated global funds are constructed from actual global funds and specialized funds in the mutual fund same family by minimizing the variance of returns subject to a restriction on expected returns. The simulations use portfolios that include the longest time series for each global fund in each family. Global funds are world funds, foreign funds, and a pool of world or foreign funds. The pools of world or foreign funds are simulations that include several world (or foreign) funds within the same family but with different scopes, e.g. world (foreign) value funds and world (foreign) growth funds. Portfolio weights are updated daily. Realized returns of the simulated portfolios are calculated out of-sample, as described in the main text. Annualized differences in accumulated returns are calculated over the entire sample for each simulation performed. Averages across simulations are then computed and reported. 
Appendix Table 5B. Family Simulations Using the Longest Available Sample

$\begin{aligned} & \text { Mutual Fund Family } \\ 1 & \text { Allianz Funds } \\ 2 & \text { Alliance Bernstein } \\ 3 & \text { American Funds Group } \\ 4 & \text { AIM Family of Funds } \\ 5 & \text { Columbia Funds } \\ 6 & \text { Credit Suisse } \\ 7 & \text { DFA Investment Dimensions Group } \\ 8 & \text { Dreyfus Founders } \\ 9 & \text { Evergreen Funds } \\ 10 & \text { Eaton Vance Group } \\ 11 & \text { Excelsior Funds } \\ 12 & \text { Fidelity Group } \\ 13 & \text { Fidelity Advisors Funds } \\ 14 & \text { GAM Funds } \\ 15 & \text { Gartmore } \\ 16 & \text { GMO LLC } \\ 17 & \text { Goldman Sachs Asset Management Group } \\ 18 & \text { Hartford Mutual Funds } \\ 19 & \text { ING Funds Trust } \\ 20 & \text { Ivy Mackenzie Management } \\ 21 & \text { Janus } \\ 22 & \text { J.P. Morgan Funds } \\ 23 & \text { MFS Family of Funds } \\ 24 & \text { Merrill Lynch Group } \\ 25 & \text { Morgan Stanley Funds } \\ 26 & \text { Oppenheimer Funds } \\ 27 & \text { Putnam Funds } \\ 28 & \text { RiverSource (former AXP) } \\ 29 & \text { Scudder Funds } \\ 30 & \text { Smith Barney Group } \\ 31 & \text { Seligman Group } \\ 32 & \text { Templeton Group } \\ 33 & \text { T. Rowe Price Funds } \\ 34 & \text { UBS Funds } \\ 35 & \text { Vanguard Group } \\ 36 & \text { Wells Fargo Advantage } \\ & \text { Total } \\ & \end{aligned}$

\begin{tabular}{|c|c|c|c|c|c|}
\hline \multicolumn{6}{|c|}{ Maximizing Expected Returns } \\
\hline \multicolumn{2}{|c|}{$\begin{array}{c}\text { Average Returns } \\
\text { (Per Year) }\end{array}$} & \multirow{2}{*}{$\begin{array}{c}\text { Average Difference } \\
\text { in Accumulated } \\
\text { Daily Returns }\end{array}$} & \multicolumn{2}{|c|}{$\begin{array}{l}\text { Standard Deviation } \\
\text { of Daily Returns }\end{array}$} & \multirow[b]{2}{*}{$\begin{array}{c}\text { Number of } \\
\text { Comparisons }\end{array}$} \\
\hline $\begin{array}{l}\text { Global } \\
\text { Funds }\end{array}$ & $\begin{array}{c}\text { Simulated Global } \\
\text { Funds }\end{array}$ & & $\begin{array}{l}\text { Global } \\
\text { Funds }\end{array}$ & $\begin{array}{c}\text { Simulated Global } \\
\text { Funds }\end{array}$ & \\
\hline $0.95 \%$ & $-3.95 \%$ & $-4.79 \%$ & $0.66 \%$ & $0.65 \%$ & 2 \\
\hline $9.36 \%$ & $12.64 \%$ & $3.08 \%$ & $0.89 \%$ & $0.86 \%$ & 8 \\
\hline $10.57 \%$ & $11.76 \%$ & $1.22 \%$ & $0.87 \%$ & $0.81 \%$ & 4 \\
\hline $7.34 \%$ & $15.96 \%$ & $8.42 \%$ & $1.03 \%$ & $0.91 \%$ & 10 \\
\hline $14.17 \%$ & $17.15 \%$ & $2.94 \%$ & $0.92 \%$ & $0.80 \%$ & 3 \\
\hline $8.46 \%$ & $10.91 \%$ & $2.40 \%$ & $0.95 \%$ & $0.89 \%$ & 2 \\
\hline $3.15 \%$ & $1.31 \%$ & $-1.53 \%$ & $0.91 \%$ & $0.78 \%$ & 4 \\
\hline $4.71 \%$ & $6.54 \%$ & $2.09 \%$ & $1.02 \%$ & $0.91 \%$ & 6 \\
\hline $5.76 \%$ & $7.06 \%$ & $1.54 \%$ & $1.07 \%$ & $0.98 \%$ & 2 \\
\hline$-4.98 \%$ & $5.23 \%$ & $11.44 \%$ & $1.13 \%$ & $0.92 \%$ & 2 \\
\hline $1.58 \%$ & $1.69 \%$ & $0.20 \%$ & $0.99 \%$ & $0.96 \%$ & 2 \\
\hline $7.08 \%$ & $8.26 \%$ & $1.27 \%$ & $0.92 \%$ & $0.85 \%$ & 6 \\
\hline $7.40 \%$ & $10.33 \%$ & $2.84 \%$ & $0.93 \%$ & $0.89 \%$ & 6 \\
\hline $2.60 \%$ & $2.45 \%$ & $0.02 \%$ & $1.03 \%$ & $0.98 \%$ & 2 \\
\hline $22.30 \%$ & $18.99 \%$ & $-2.66 \%$ & $0.81 \%$ & $0.80 \%$ & 3 \\
\hline $6.65 \%$ & $9.26 \%$ & $2.41 \%$ & $0.76 \%$ & $0.80 \%$ & 8 \\
\hline $1.63 \%$ & $4.30 \%$ & $2.83 \%$ & $1.03 \%$ & $0.97 \%$ & 6 \\
\hline $6.10 \%$ & $8.78 \%$ & $2.80 \%$ & $1.04 \%$ & $0.93 \%$ & 2 \\
\hline $0.96 \%$ & $5.35 \%$ & $5.32 \%$ & $1.04 \%$ & $0.91 \%$ & 6 \\
\hline $2.45 \%$ & $6.80 \%$ & $4.56 \%$ & $0.92 \%$ & $0.84 \%$ & 4 \\
\hline $4.97 \%$ & $10.57 \%$ & $5.33 \%$ & $0.88 \%$ & $0.89 \%$ & 5 \\
\hline $22.11 \%$ & $23.09 \%$ & $0.88 \%$ & $0.90 \%$ & $0.87 \%$ & 4 \\
\hline $12.47 \%$ & $14.85 \%$ & $2.09 \%$ & $0.80 \%$ & $0.82 \%$ & 3 \\
\hline $5.09 \%$ & $8.85 \%$ & $3.87 \%$ & $1.03 \%$ & $0.94 \%$ & 9 \\
\hline $2.47 \%$ & $7.53 \%$ & $5.22 \%$ & $0.97 \%$ & $0.93 \%$ & 11 \\
\hline $12.15 \%$ & $13.54 \%$ & $1.28 \%$ & $0.77 \%$ & $0.77 \%$ & 4 \\
\hline $4.86 \%$ & $5.03 \%$ & $0.26 \%$ & $1.08 \%$ & $1.05 \%$ & 5 \\
\hline $3.46 \%$ & $2.53 \%$ & $-0.46 \%$ & $1.14 \%$ & $0.99 \%$ & 2 \\
\hline $5.44 \%$ & $11.08 \%$ & $5.49 \%$ & $0.99 \%$ & $0.95 \%$ & 9 \\
\hline $2.03 \%$ & $2.41 \%$ & $0.38 \%$ & $0.94 \%$ & $0.93 \%$ & 1 \\
\hline $14.45 \%$ & $16.85 \%$ & $2.07 \%$ & $0.82 \%$ & $0.84 \%$ & 2 \\
\hline $3.15 \%$ & $4.13 \%$ & $1.13 \%$ & $0.80 \%$ & $0.72 \%$ & 9 \\
\hline $5.04 \%$ & $9.40 \%$ & $4.37 \%$ & $0.98 \%$ & $0.92 \%$ & 6 \\
\hline $4.41 \%$ & $6.71 \%$ & $2.27 \%$ & $0.89 \%$ & $0.85 \%$ & 1 \\
\hline $5.40 \%$ & $5.17 \%$ & $-0.15 \%$ & $0.99 \%$ & $0.98 \%$ & 4 \\
\hline $6.44 \%$ & $13.25 \%$ & $6.77 \%$ & $1.01 \%$ & $0.87 \%$ & 2 \\
\hline $6.13 \%$ & $9.08 \%$ & $3.02 \%$ & $0.94 \%$ & $0.88 \%$ & 165 \\
\hline
\end{tabular}

This table shows differences in the average and standard deviation of returns between global funds and simulated global funds by mutual fund family. Simulated global funds are constructed from actual global funds and specialized funds in the same mutual fund family by maximizing expected returns subject to a restriction on the variance of returns. The simulations use portfolios that include the longest time series for each global fund in each family. Global funds are world funds, foreign funds, and a pool of world or foreign funds. The pools of world or foreign funds are simulations that include several world (or foreign) funds within the same family but with different scopes, e.g. world (foreign) value funds and world (foreign) growth funds. Portfolio weights are updated daily. Realized returns of the simulated portfolios are calculated out-of-sample, as described in the main text. Annualized differences in accumulated returns are calculated over the entire sample for each simulation performed. Averages across simulations are then computed and reported. 
Appendix Table 6A. Rolling Window Simulations Using the Largest Number of Funds

\begin{tabular}{|c|c|c|c|c|c|c|}
\hline \multirow[b]{3}{*}{ Type of Global Fund } & \multicolumn{6}{|c|}{ Minimizing the Variance } \\
\hline & \multicolumn{2}{|c|}{$\begin{array}{c}\text { Average Returns } \\
\text { (Per Year) }\end{array}$} & \multirow{2}{*}{$\begin{array}{c}\text { Average } \\
\text { Difference in } \\
\text { Accumulated } \\
\text { Daily Returns } \\
\end{array}$} & \multicolumn{2}{|c|}{$\begin{array}{c}\text { Standard Deviation of Daily } \\
\text { Returns }\end{array}$} & \multirow[b]{2}{*}{$\begin{array}{c}\text { Number of } \\
\text { Comparisons } \\
\end{array}$} \\
\hline & $\begin{array}{l}\text { Global } \\
\text { Funds }\end{array}$ & $\begin{array}{c}\text { Simulated } \\
\text { Global Funds } \\
\end{array}$ & & $\begin{array}{l}\text { Global } \\
\text { Funds }\end{array}$ & $\begin{array}{c}\text { Simulated } \\
\text { Global Funds }\end{array}$ & \\
\hline World Stock & $9.10 \%$ & $13.80 \%$ & $4.52 \%$ & $0.87 \%$ & $0.77 \%$ & 55 \\
\hline Foreign Stock & $6.22 \%$ & $10.19 \%$ & $4.11 \%$ & $0.97 \%$ & $0.87 \%$ & 75 \\
\hline Pools of World or Foreign Funds & $11.81 \%$ & $13.78 \%$ & $1.64 \%$ & $0.81 \%$ & $0.75 \%$ & 22 \\
\hline \multirow[t]{3}{*}{ Total } & $8.05 \%$ & $12.00 \%$ & $3.90 \%$ & $0.91 \%$ & $0.82 \%$ & 152 \\
\hline & \multicolumn{6}{|c|}{ Maximizing Expected Returns } \\
\hline & \multicolumn{2}{|c|}{$\begin{array}{c}\text { Average Returns } \\
\text { (Per Year) }\end{array}$} & \multirow{2}{*}{$\begin{array}{c}\text { Average } \\
\text { Difference in } \\
\text { Accumulated } \\
\text { Daily Returns }\end{array}$} & \multicolumn{2}{|c|}{$\begin{array}{c}\text { Standard Deviation of Daily } \\
\text { Returns }\end{array}$} & \\
\hline Type of Global Fund & $\begin{array}{l}\text { Global } \\
\text { Funds }\end{array}$ & $\begin{array}{c}\text { Simulated } \\
\text { Global Funds } \\
\end{array}$ & & $\begin{array}{l}\text { Global } \\
\text { Funds }\end{array}$ & $\begin{array}{c}\text { Simulated } \\
\text { Global Funds }\end{array}$ & $\begin{array}{c}\text { Number of } \\
\text { Comparisons } \\
\end{array}$ \\
\hline World Stock & $9.10 \%$ & $14.01 \%$ & $4.59 \%$ & $0.87 \%$ & $0.83 \%$ & 55 \\
\hline Foreign Stock & $6.22 \%$ & $10.93 \%$ & $4.76 \%$ & $0.97 \%$ & $0.93 \%$ & 75 \\
\hline Pools of World or Foreign Funds & $11.81 \%$ & $14.28 \%$ & $1.89 \%$ & $0.81 \%$ & $0.78 \%$ & 22 \\
\hline Total & $8.05 \%$ & $12.52 \%$ & $4.28 \%$ & $0.91 \%$ & $0.87 \%$ & 152 \\
\hline
\end{tabular}

This table shows differences in the average and standard deviation of returns between global funds and simulated global funds. Simulations only use information on the previous 240 business days at each point in time. Simulated global funds are constructed from actual global funds and specialized funds in the same mutual fund family using two different procedures. The top panel shows the results of minimizing the variance of returns subject to a restriction on expected returns. The bottom panel shows the results of maximizing expected returns subject to a restriction on the variance of returns. The simulations use portfolios that include the largest number of available specialized funds for each global fund in each family. Global funds are world funds, foreign funds, and a pool of world or foreign funds. The pools of world or foreign funds are simulations that include several world (or foreign) funds within the same family but with different scopes, e.g. world (foreign) value funds and world (foreign) growth funds. Portfolio weights are updated daily. Realized returns of the simulated portfolios are calculated out-of-sample, as described in the main text. Annualized differences in accumulated returns are calculated over the entire sample for each simulation performed. Averages across simulations are then computed and reported. 
Appendix Table 6B. Rolling Window Simulations Using the Longest Available Sample

\begin{tabular}{|c|c|c|c|c|c|c|}
\hline \multirow[b]{3}{*}{ Type of Global Fund } & \multicolumn{6}{|c|}{ Minimizing the Variance } \\
\hline & \multicolumn{2}{|c|}{$\begin{array}{c}\text { Average Returns } \\
\text { (Per Year) }\end{array}$} & \multirow{2}{*}{$\begin{array}{c}\text { Average Difference } \\
\text { in Accumulated } \\
\text { Daily Returns } \\
\end{array}$} & \multicolumn{2}{|c|}{$\begin{array}{c}\text { Standard Deviation of Daily } \\
\text { Returns }\end{array}$} & \multirow[b]{2}{*}{$\begin{array}{c}\text { Number of } \\
\text { Comparisons } \\
\end{array}$} \\
\hline & $\begin{array}{l}\text { Global } \\
\text { Funds }\end{array}$ & $\begin{array}{c}\text { Simulated } \\
\text { Global Funds }\end{array}$ & & $\begin{array}{l}\text { Global } \\
\text { Funds }\end{array}$ & $\begin{array}{c}\text { Simulated } \\
\text { Global Funds }\end{array}$ & \\
\hline World Stock & $8.03 \%$ & $10.46 \%$ & $2.53 \%$ & $0.90 \%$ & $0.82 \%$ & 62 \\
\hline Foreign Stock & $5.35 \%$ & $8.17 \%$ & $2.99 \%$ & $0.98 \%$ & $0.89 \%$ & 75 \\
\hline Pools of World or Foreign Funds & $10.45 \%$ & $12.94 \%$ & $2.44 \%$ & $0.88 \%$ & $0.79 \%$ & 23 \\
\hline \multirow[t]{3}{*}{ Total } & $7.10 \%$ & $9.73 \%$ & $2.73 \%$ & $0.93 \%$ & $0.85 \%$ & 160 \\
\hline & \multicolumn{6}{|c|}{ Maximizing Expected Returns } \\
\hline & \multicolumn{2}{|c|}{$\begin{array}{c}\text { Average Returns } \\
\text { (Per Year) }\end{array}$} & Average Difference & \multicolumn{2}{|c|}{$\begin{array}{c}\text { Standard Deviation of Daily } \\
\text { Returns }\end{array}$} & \multirow[b]{2}{*}{$\begin{array}{c}\text { Number of } \\
\text { Comparisons } \\
\end{array}$} \\
\hline Type of Global Fund & $\begin{array}{l}\text { Global } \\
\text { Funds } \\
\end{array}$ & $\begin{array}{c}\text { Simulated } \\
\text { Global Funds } \\
\end{array}$ & $\begin{array}{c}\text { in Accumulated } \\
\text { Daily Returns } \\
\end{array}$ & $\begin{array}{l}\text { Global } \\
\text { Funds }\end{array}$ & $\begin{array}{c}\text { Simulated } \\
\text { Global Funds } \\
\end{array}$ & \\
\hline World Stock & $8.03 \%$ & $10.85 \%$ & $2.82 \%$ & $0.90 \%$ & $0.84 \%$ & 62 \\
\hline Foreign Stock & $5.35 \%$ & $8.16 \%$ & $2.90 \%$ & $0.98 \%$ & $0.93 \%$ & 75 \\
\hline Pools of World or Foreign Funds & $10.45 \%$ & $12.89 \%$ & $2.22 \%$ & $0.88 \%$ & $0.84 \%$ & 23 \\
\hline Total & $7.10 \%$ & $9.87 \%$ & $2.77 \%$ & $0.93 \%$ & $0.88 \%$ & 160 \\
\hline \multicolumn{7}{|c|}{$\begin{array}{l}\text { This table shows differences in the average and standard deviation of returns between global funds and simulated global funds. Simulations only } \\
\text { use information on the previous } 240 \text { business days at each point in time. Simulated global funds are constructed from actual global funds and } \\
\text { specialized funds in the same mutual fund family using two different procedures. The top panel shows the results of minimizing the variance of } \\
\text { returns subject to a restriction on expected returns. The bottom panel shows the results of maximizing expected returns subject to a restriction on } \\
\text { the variance of returns. The simulations use portfolios that include the longest time series for each global fund in each family. Global funds are } \\
\text { world funds, foreign funds, and a pool of world or foreign funds. The pools of world or foreign funds are simulations that include several world } \\
\text { (or foreign) funds within the same family but with different scopes, e.g. world (foreign) value funds and world (foreign) growth funds. Portfolio } \\
\text { weights are updated daily. Realized returns of the simulated portfolios are calculated out-of-sample, as described in the main text. Annualized } \\
\text { differences in accumulated returns are calculated over the entire sample for each simulation performed. Averages across simulations are then } \\
\text { computed and reported. }\end{array}$} \\
\hline
\end{tabular}

